\title{
DANOS E BIOLOGIA DE Spodoptera frugiperda (J.E. SMITH, 1797) (LEPIDOPTERA: NOCTUIDAE) EM GENÓTIPOS DE MILHO
}

\section{ROMILDO CÁSSIO SILOTO}

\author{
Dissertação apresentada à Escola \\ Superior de Agricultura "Luiz de Queiroz", \\ Universidade de São Paulo, para \\ obtenção do título de Mestre em Ciências, \\ Área de Concentração: Entomologia.
}

PIRACICABA

Estado de São Paulo - Brasil

Outubro - 2002 


\title{
DANOS E BIOLOGIA DE Spodoptera frugiperda (J.E. SMITH, 1797) (LEPIDOPTERA: NOCTUIDAE) EM GENÓTIPOS DE MILHO
}

\author{
ROMILDO CÁSSIO SILOTO \\ Biólogo
}

Orientador: Prof. Dr. JOSÉ DJAIR VENDRAMIM

Dissertação apresentada à Escola
Superior de Agricultura "Luiz de Queiroz",
Universidade de São Paulo, para
obtenção do título de Mestre em Ciências,
Área de Concentração: Entomologia.

PIRACICABA

Estado de São Paulo - Brasil

Outubro - 2002 
Dados Internacionais de Catalogação na Publicação (CIP)

DIVISÃO DE BIBLIOTECA E DOCUMENTAÇÃO - ESALQ/USP

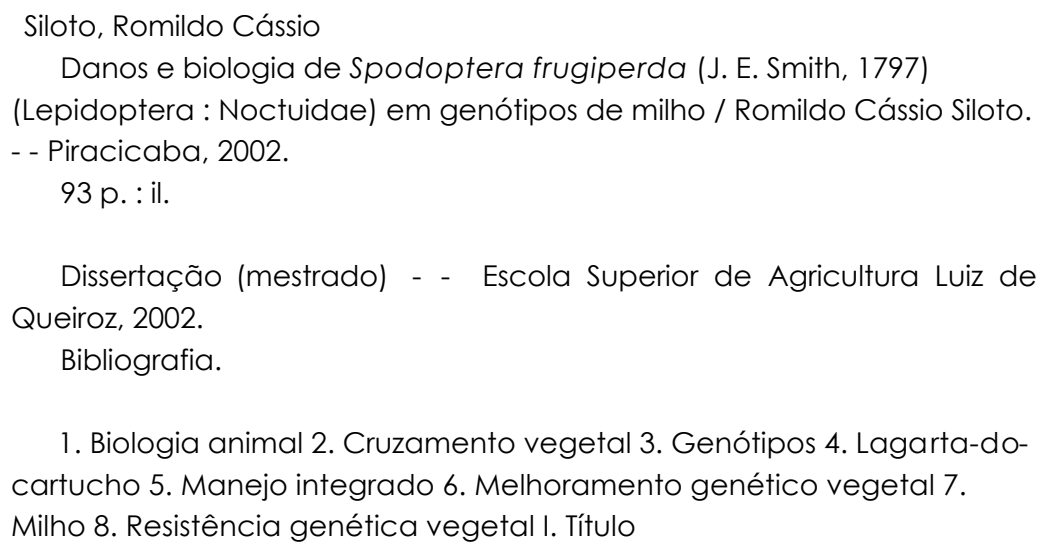

CDD 633.15

\section{"Permitida a cópia total ou parcial deste documento, desde que citada a fonte}




\section{DEDICATÓRIA}

\begin{abstract}
À VIDA
Por sua generosidade. Por ter me permitido a escolha entre os caminhos. E no caminho escolhido, ter me proporcionado a esperança; a boa vontade; a boa saúde; a presença de meus familiares; de meus professores; de meus amigos; de pessoas, conhecidas ou anônimas, os quais vêm contribuindo para que eu possa prosseguir na jornada.
\end{abstract}

"Manoel, o audaz, vamos lá... ... aprender ou mais tentar! Manoel, o audaz, iremos tentar, vamos aprender, vamos lá!"

Manoel, o audaz (Toninho Horta) 


\section{AGRADECIMENTOS}

Ao Prof. Dr. José Djair Vendramim, pela sua dedicação na orientação deste trabalho, e sobretudo, pela amizade construída ao longo de nossa convivência.

Ao Dr. Adalton Raga, pesquisador científico do Laboratório de Entomologia Econômica do Instituto Biológico, pelo seu apoio, incentivo e confiança.

Ao Instituto Biológico, pela oportunidade concedida para a realização do curso de pós-graduação.

À ESALQ/USP, em particular, aos professores do Programa de Pósgraduação em Entomologia, pelos ensinamentos transmitidos, pela amizade, incentivo e apoio.

À Dra. Maria Elisa A. G. Zagatto Paterniani, pesquisadora científica do Centro de Análise e Pesquisa Tecnológica do Agronegócio dos Grãos e Fibras, do Instituto Agronômico de Campinas, pelo apoio e incentivo.

Aos funcionários do Pólo Regional de Desenvolvimento Tecnológico do Agronegócio do Médio Paranapanema, em Assis - SP, representados na pessoa do Dr. Aildson Pereira Duarte, pelo apoio logístico e operacional e pelo fornecimento das sementes dos genótipos utilizados neste trabalho. 
Aos agricultores, Sr. João Pascon Ceciliato (Florínea - SP), Sr. Maurício Sakai (Guaíra - SP), Sr. Mário Kubo (Miguelópolis - SP) e ao gerente agrícola da Fazenda Boa Vista, Sr. Antônio Carlos Orfei (Casa Branca - SP), por terem cedido, em suas propriedades, as áreas para realização dos experimentos de campo.

Ao Sr. Helymar Costa Machado, pelo auxílio nas análises estatísticas.

Aos funcionários e estagiários do Instituto Biológico, pela colaboração, incentivo e amizade.

Àqueles, conhecidos ou anônimos, que direta ou indiretamente colaboraram na realização deste trabalho, os sinceros agradecimentos. 


\section{SUMÁRIO}

Página

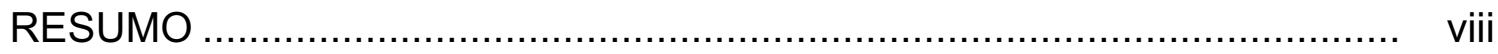

SUMMARY

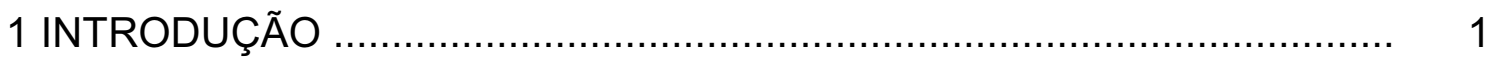

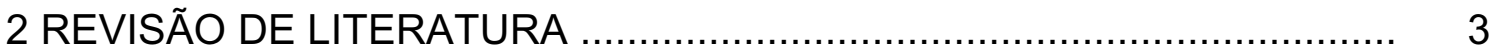

2.1 Breve histórico e importância socio-econômica do milho........................ 4

2.2 Aspectos de distribuição, bioecologia e importância econômica de $S$.

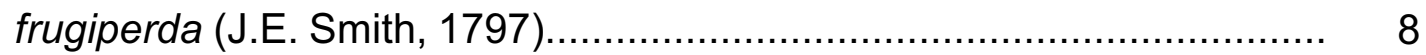

2.3 Metodologias de infestação e avaliação para detecção de genótipos resistentes

2.4 Disponibilização e recomendação de genótipos resistentes 20

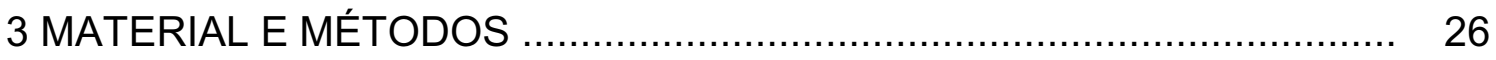

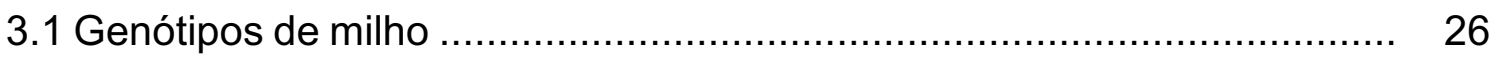

3.2 Experimentos em condições de campo ...................................... 27

3.2.1 Locais e épocas de cultivo .................................................. 27

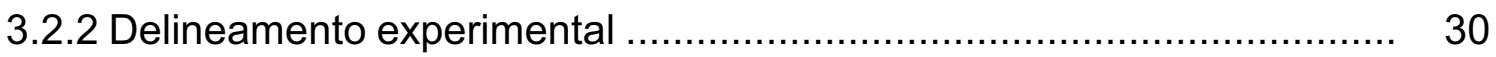

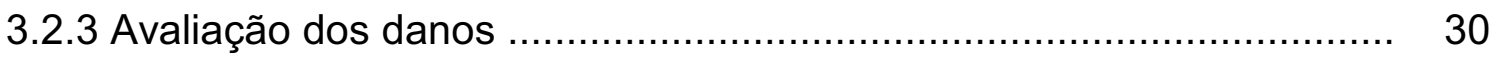

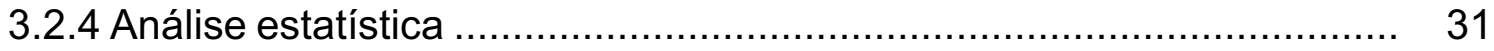

3.3 Experimentos em condições de laboratório ................................. 34

3.3.1 Desenvolvimento de S. frugiperda em genótipos de milho ................. 35

3.3.2 Não-preferência para alimentação de lagartas de S. frugiperda em genótipos de milho ..................................................... 37

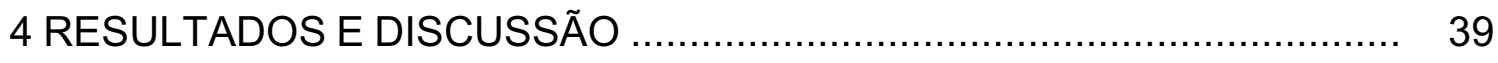

4.1 Experimentos em condições de campo .................................... 39 
4.1.1 Análise da variância conjunta entre locais e entre idades, dentro dos locais

4.1.2 Resultados da análise de variância conjunta em Casa Branca - SP ... 45

4.1.3 Resultados da análise de variância conjunta em Florínea - SP ......... 52

4.1.4 Resultados da análise de variância conjunta em Miguelópolis/Guaíra - região norte - SP .............................................................. 57

4.1.5 Análise de agrupamento .................................................... 61

4.1.6 Considerações gerais sobre os experimentos de campo ................... 62

4.2 Experimentos em condições de laboratório ........................................ 66

4.2.1 Desenvolvimento de $S$. frugiperda em genótipos de milho ................ 66

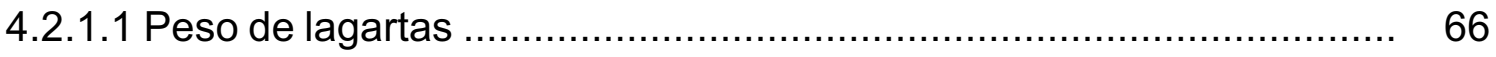

4.2.1.2 Duração e viabilidade da fase larval ........................................... 67

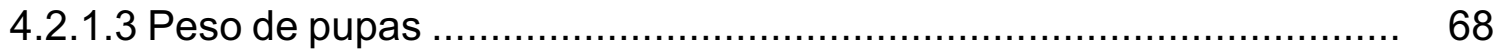

4.2.1.4 Duração e viabilidade da fase pupal ............................................ 69

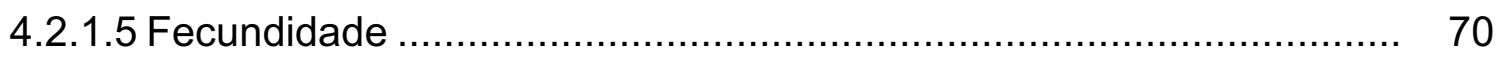

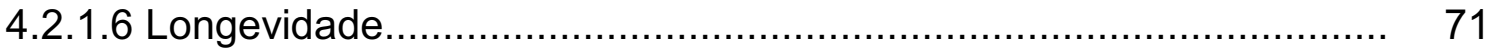

4.2.1.7 Deformação de pupas e adultos .............................................. 72

4.2.1.8 Análise de agrupamento ......................................................... 73

4.2.2 Não-preferência para alimentação de lagartas de $S$. frugiperda em

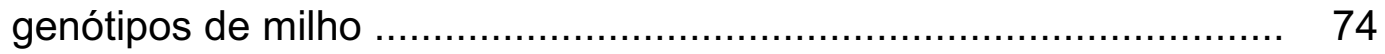

4.2.3 Considerações gerais sobre experimentos de laboratório ….............. 75

4.3 Comportamento de alguns genótipos nos experimentos de campo e de

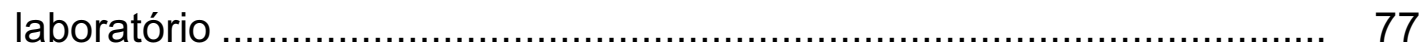

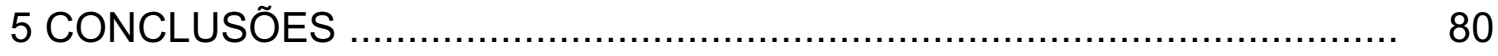

REFERÊNCIAS BIBLIOGRÁFICAS .................................................... 82 


\section{DANOS E BIOLOGIA DE Spodoptera frugiperda (J.E. SMITH, 1797) (LEPIDOPTERA: NOCTUIDAE) EM GENÓTIPOS DE MILHO}

Autor: ROMILDO CÁSSIO SILOTO Orientador: Prof. Dr. JOSÉ DJAIR VENDRAMIM

\section{RESUMO}

A utilização de variedades resistentes é uma importante ferramenta no manejo integrado de pragas e vem sendo valorizada nos programas de melhoramento de plantas. Neste estudo foram avaliados 12 genótipos de milho, em relação aos danos causados por Spodoptera frugiperda (J.E. Smith, 1797) em condições de campo, e em relação ao efeito desses genótipos na biologia da praga, em condições de laboratório. Os experimentos de campo foram realizados nos municípios de Casa Branca, Florínea e Miguelópolis/Guaíra, representando três diferentes regiões do Estado de São Paulo. As plantas foram avaliadas nas idades de 6 a 8 e de 10 a 12 folhas, através de uma escala de notas de 0 a 9 . Os resultados da análise de variância mostraram que os danos causados pela lagarta-do-cartucho nos genótipos de milho foram diferentes nos três locais avaliados. A interação idade*local foi significativa, indicando que, dependendo do local avaliado, os danos foram diferentes em cada idade. Na idade de 6 a 8 folhas, os danos foram significativamente menores em Casa Branca em relação à Florínea e à Miguelópolis/Guaíra. Na idade de 10 a 12 folhas, os três locais apresentaram danos significativamente distintos. Miguelópolis/Guaíra foi 0 local 
que apresentou menos danos, em relação à Florínea. Casa Branca foi o local em que ocorreu mais danos. Na comparação das médias entre as idades em cada local, Casa Branca apresentou os menores danos na idade de 6 a 8 folhas, enquanto que, em Florínea e Miguelópolis/Guaíra, isso ocorreu na idade de 10 a 12 folhas. Com base na análise de agrupamento para os experimentos de campo, os genótipos Z 8486, C 333 B e Dina 766 formaram o grupo daqueles menos danificados, enquanto que os genótipos XL 212 e Piranão formaram o grupo dos mais danificados pela lagarta-do-cartucho. Houve pouco efeito dos genótipos avaliados sobre a biologia do inseto. Nos experimentos de laboratório, os genótipos Z 8486 e Master proporcionaram menor peso de lagartas aos 7 e 14 dias, em relação aos genótipo XL 212, enquanto em Z 8486 e IAC-Vitória ocorreu menor viabilidade larval em relação à Dina 766. O genótipo Dina 766, que ficou entre os menos danificados em condições de campo, proporcionou maior peso larval aos 7 dias e maior viabilidade larval. 


\title{
DAMAGE AND BIOLOGY OF Spodoptera frugiperda (J.E. SMITH, 1797) (LEPIDOPTERA: NOCTUIDAE) ON MAIZE GENOTYPES
}

\author{
Author: ROMILDO CÁSSIO SILOTO \\ Adviser: Prof. Dr. JOSÉ DJAIR VENDRAMIM
}

\section{SUMMARY}

Plant resistance is a useful component of integrated pest management and its value has been increasing in plant breeding programs. In this study, 12 maize genotypes were evaluated to damage of fall armyworm Spodoptera frugiperda (J.E. Smith, 1797) in field conditions. The effect of these genotypes on fall armyworm biology was evaluated in laboratory conditions. The field experiments were carried out in Casa Branca, Florínea and Miguelópolis/Guaíra, which represent three different regions of São Paulo State. The plants were evaluated at 6-8 and 10-12 exposed leaves, using a rank scale from 0 to 9 . The analysis of variance showed that the fall armyworm damage on maize genotypes differed in each of three places. The interaction age* place was significant and it indicates that the damage differed according to the age of the plants, depending on where they were evaluated. At 6-8 leaf stage, the damage were less significant in Casa Branca comparing to Florínea and Miguelópolis/Guaíra. At 10-12 leaf stage, the three places showed damage with significant differences. Miguelópolis/Guaíra was the place with fewer damage, comparing to Florínea. In Casa Branca occurred more damage. Comparing the 
age average of the plants in each region, the plants in Casa Branca showed fewer damage at 6-8 leaf stage whereas the plants in Florínea and Miguelópolis/Guaíra showed it at 10-12 leaf stage. In the field experiments, the Cluster Analysis showed that Z 8486, C 333 B and Dina 766 genotypes set the group with fewer fall armyworm damage whereas XL 212 and Piranão genotypes set the most damaged group. The genotypes provided little effect on fall armyworm biology. In the laboratory experiments, the larvae reared on $Z$ 8486 and Master genotypes provided lower weight on days 7 and 14, when comparing to XL 212. The genotypes Z 8486 and IAC-Vitória presented lower larval survival when comparing to Dina 766 . The larvae reared on Dina 766 genotype provided the highest weight for day 7 and the greatest larval survival, even though, this genotype was one of the least damaged in the field. 


\section{INTRODUÇÃO}

No Brasil, o milho é cultivado na grande maioria das propriedades agrícolas, sendo explorado tanto em pequenas propriedades, com baixa utilização de tecnologia e em caráter de subsistência, como em propriedades onde se emprega alta tecnologia, com elevada produtividade, tornando-se matéria-prima para a agroindústria.

Com uma área plantada em torno de 12,7 milhões de hectares e uma produção média de 35 milhões de toneladas, o país ocupa a terceira posição na produção mundial, atrás dos Estados Unidos e da China (FNP Consultoria \& Comércio, 2002).

No Estado de São Paulo, o milho é cultivado em todas as regiões e em muitas delas explora-se também o cultivo na segunda safra, em sucessão à cultura da soja ou mesmo do próprio milho. A produtividade média do Estado é de 3 toneladas por hectare, com produção média de 3,6 milhões de toneladas e área plantada estimada em 1,2 milhões de hectares, sendo que na segunda safra a área ocupada se aproxima de $50 \%$ do total plantado na safra principal (FNP Consultoria \& Comércio, 2002; Instituto de Economia Agrícola, 2000).

As empresas de produção de sementes e instituições de pesquisa colocam no mercado, a cada ano, dezenas de novas cultivares, mas a grande heterogeneidade de material genético e de fatores abióticos e bióticos influenciam o comportamento das cultivares nas diferentes regiões.

Dentre os fatores bióticos, as pragas constituem-se em elemento relevante. $\mathrm{Na}$ cultura do milho, os gastos com inseticidas representam em média $15 \%$ do custo operacional efetivo. A lagarta-do-cartucho Spodoptera 
frugiperda (J.E. Smith, 1797) é considerada a praga-chave da cultura em condições de campo, causando danos em praticamente toda a fase vegetativa do milho comprometendo a produção.

O controle químico dessa praga tem demandado significativo aumento no número de pulverizações com inseticidas, causando o surgimento de populações resistentes aos diferentes produtos químicos disponíveis, bem como implicações no meio ambiente.

A utilização da resistência varietal por meio de melhoramento genético é uma importante ferramenta no controle de pragas. Atualmente, o método de resistência de plantas a insetos tem sido valorizado dentro dos programas de melhoramento de plantas.

A Secretaria de Agricultura e Abastecimento do Estado de São Paulo desenvolve um programa que realiza avaliações regionais de cultivares de milho visando fornecer informações técnicas aos agricultores. Esse sistema não contempla ainda a avaliação de cultivares em relação às pragas. Entretanto, tem sido observado nas diferentes regiões que alguns desses materiais são menos danificados pela lagarta-do-cartucho, os quais podem carregar na sua bagagem genética fontes de resistência à referida praga.

O objetivo deste trabalho foi avaliar materiais genéticos de milho, alguns deles comercializados no Brasil, visando mensurar o grau de resistência a $S$. frugiperda, por meio da avaliação do dano e do efeito sobre a biologia da praga. 


\section{REVISÃO DE LITERATURA}

Resistência de plantas a insetos é um eficiente método de controle de pragas, produzindo vantagens biológicas, econômicas e ambientais (Hamm \& Wisemam, 1986).

É uma ciência única, que requer trabalho cooperativo e integrado de especialistas das diferentes áreas do conhecimento. Técnicas de criação de insetos em larga escala, métodos de infestação e sistemas de avaliação têm sido constantemente aperfeiçoados no sentido de otimizar os ensaios experimentais para melhor compreensão dos mecanismos que envolvem a resistência. Considerada um método ideal de controle de pragas, possibilita a manutenção da população desses organismos abaixo do nível de dano econômico, sem causar prejuízos ao ambiente e aos agricultores. É técnica adequada para ser usada pelo agricultor, não interferindo em outras práticas culturais e apresentando, em geral, boa compatibilidade com outros métodos de controle (Vendramim \& Nishikawa, 2001).

Um programa de melhoramento de plantas visando resistência a insetos envolve diversas etapas e um bom planejamento.

Deve-se portanto obter informações a respeito da praga, do hospedeiro e da interação inseto-planta, objetivando-se a definição da praga-chave e então concentrar esforços na obtenção das fontes de resistência, se possível, identificando os mecanismos e as bases da resistência (Vendramim \& Nishikawa, 2001). 


\subsection{Breve histórico e importância socio-econômica do milho}

Paterniani \& Campos (1999) e Paterniani et al. (2000) fizeram extenso e abrangente relato sobre a cultura do milho, abordando os aspectos históricos da cultura, das pesquisas em melhoramento de plantas e dos recursos genéticos do milho para o Brasil.

Segundo esses autores, o milho é provavelmente originário das Américas, mormente do México, sendo domesticado pelos povos da América Central, que por seleção desenvolveram inúmeras raças ao longo dos últimos 8.000 anos. Fora dessa região não há registros históricos de sua existência. Provavelmente, por ocasião do descobrimento da América, Cristóvão Colombo tenha conhecido o milho e levado sementes desse cereal para a Espanha. A partir daí tornou-se parte integrante da dieta dos mais variados povos, o que incrementou a sua importância econômica.

Hoje o milho encontra-se disseminado por todo o mundo, com várias introduções feitas a partir de milhos americanos. Na Itália os "grãos duros laranja" foram os inicialmente preferidos, sendo atualmente desenvolvidos os semi-dentados originados dos "Corn Belt". Nos Estados Unidos predominam os "dentado amarelo" pelo seu potencial produtivo. O México utiliza o "dentado branco", principalmente no preparo das "tortillas". "Duros e semi-duros brancos" são os utilizados na Venezuela, principalmente no preparo do pão "aripa". $\mathrm{Na}$ Argentina a ênfase é dada à produção do milho "duro laranja intenso", destinado à exportação. No Brasil, entre os milhos indígenas, a maioria era constituída de grãos amarelos e brancos, muito moles, favoráveis à produção de farinhas. Havia também os redondos e pontudos (pipocas) e os de grãos duro, laranjas e brancos, os quais tiveram importância em melhoramento, originando principalmente os "Catetos" (duro de cor laranja). Com o cruzamento dos catetos locais com os dentados introduzidos dos Estados Unidos, originaram-se diversas variedades de dentados amarelos, coletivamente chamados de "Dente Paulista". Atualmente tem-se explorado a heterose 
resultante dos cruzamentos entre dentados e duros, o que resultou no tipo semi-dentado amarelo (Paterniani \& Campos, 1999; Paterniani et al., 2000).

O milho é uma espécie cultivada com altíssimo índice de domesticação, sobrevivendo somente quando cultivado pelo homem, uma vez que perdeu a capacidade de existir por si mesmo na natureza.

É uma gramínea pertencente à família Poaceae, tribo Maydeae, gênero Zea e espécie mays (Zea mays L). Possui ampla variabilidade genética sendo identificadas atualmente cerca de 300 raças e, dentro de cada raça, inúmeras variedades. Essa grande variabilidade se traduz também quanto às adaptações climáticas, de altitude e latitude, em características agronômicas desejáveis, no tamanho e composição química de grãos, tipo de endosperma e qualidade das proteínas (Paterniani et al., 2000).

Com relação ao tipo de endosperma, cerca de $40 \%$ são amiláceos, $30 \%$ são de grãos duros cristalinos, pouco mais de $20 \%$ são dentados, $10 \%$ são pipocas e cerca de 3\% são milho-doce (Paterniani \& Campos, 1999). Os complexos raciais foram agrupados por Goodman (1978), citado por Paterniani \& Campos (1999), em amiláceos, duros ou cristalinos, dentados, pipocas e doces. O complexo racial de "Dentados Mexicanos" (Tuxpeño, Vandeño, Zapalotes) é de grande significado no desenvolvimento de variedades comerciais de milho. A raça Tuxpeño é a fonte mais utilizada, pois além de possuir caracteres agronômicos desejáveis, tem grande habilidade combinatória, sendo muito importante no desenvolvimento de melhoramento, principalmente no Brasil (Nass \& Paterniani, 2000).

No Brasil, os primeiros trabalhos de melhoramento foram iniciados em 1932, no Instituto Agronômico de Campinas (IAC) - SP e em 1935, na Universidade Federal de Viçosa - MG. A partir de um programa de híbridos composto por linhagens de catetos e milhos dentados foi originado um híbrido meio-dente. Na década de 60, a Escola Superior de Agricultura "Luiz de Queiroz" - ESALQ/USP iniciou o melhoramento de populações; no início da década seguinte foram lançadas as primeiras variedades, também com a 
contribuição do IAC. Isso só foi possível em razão do desenvolvimento, no Departamento de Genética da ESALQ, de um "Banco de Germoplasma de Milho" (Paterniani et al., 2000).

Nass \& Paterniani (2000) destacaram a importância dos recursos genéticos e as atividades que envolvem a rotina dos bancos de germoplasma. Ressaltaram que são atividades que demandam qualificação de pesquisadores, com custo elevado e os resultados, em geral, aparecem a longo prazo. Devem prover a conservação da variabilidade genética para o futuro e, ao mesmo tempo, disponibilizar os acessos ao público alvo. Entretanto, consideraram como "baixa" a utilização dos bancos de germoplasma pelos melhoristas, sendo essa uma realidade mundial, não restrita somente aos países em desenvolvimento. Por outro lado, consideraram que o desenvolvimento de híbridos proporcionou resultados favoráveis na maioria dos países tropicais. Também destacaram a utilização dos cruzamentos dialélicos que permitem todos os cruzamentos possíveis entre um grupo de linhagens ou variedades. Trata-se de metodologia que vem sendo bastante utilizada, fornecendo conhecimento adequado das propriedades intrínsecas dos materiais analisados e identificando propriedades de interesse para os diversos programas de melhoramento de milho.

No Brasil, o milho é explorado na maioria das propriedades agrícolas, desde a pequena propriedade rural, onde é produzido com baixa tecnologia em caráter de subsistência, tornando-se alimento básico da população, até em grandes áreas, com emprego de alta tecnologia e com elevada produtividade, sendo matéria-prima destinada para a agroindústria.

Considerando-se as médias obtidas nos últimos cinco anos agrícolas, tem-se uma produção mundial em torno de 592 milhões de toneladas. Os maiores produtores mundiais de milho são os Estados Unidos, com 241,7 milhões de toneladas e a China, com 119,7 milhões de toneladas. O Brasil ocupa a terceira posição com 34,2 milhões de toneladas, numa média de 12,7 milhões de hectares em área plantada e produtividade próxima de $2.700 \mathrm{~kg} / \mathrm{ha}$. 
Aproximadamente $20 \%$ dessa produção corresponde à segunda safra. Em 2000/2001, houve produção recorde de 41 milhões de toneladas e produtividade de $3.200 \mathrm{~kg} / \mathrm{ha}$, com praticamente a mesma média de área plantada (FNP Consultoria \& Comércio, 2002).

No Estado de São Paulo a cultura ocupa, em média, 1,2 milhões de hectares de área plantada, com produção em torno de 3,6 milhões de toneladas e produtividade de 3 toneladas por hectare, embora exista variação bastante considerável na produtividade das diferentes regiões e nas diferentes épocas de cultivo (FNP, 2002; Instituto de Economia Agrícola, 2000). Em algumas regiões paulistas, além da exploração na safra principal, o milho é também cultivado na segunda safra, geralmente em sucessão à cultura da soja ou do próprio milho, ocupando uma área plantada próxima da metade daquela plantada na safra principal (Instituto de Economia Agrícola, 2000).

As regiões que exploram o milho safrinha apresentam condições edafoclimáticas que permitem a exploração da cultura em períodos limitantes para outras regiões (Duarte \& Paterniani, 1996). Municípios paulistas como os das regiões de São João da Boa Vista, Avaré, Itapetininga, Orlândia e Ourinhos são grandes produtores na safra principal enquanto que outros das regiões do Vale do Médio Paranapanema e Barretos possuem mais expressão na segunda safra (Duarte et al., 2000; Instituto de Economia Agrícola, 2000). Devido à grande extensão de área cultivada no Estado de São Paulo, aliada à heterogeneidade de condições edafoclimáticas e de nível tecnológico empregado, é esperado que exista grande interação genótipo*ambiente, evidenciando-se a necessidade de materiais adaptados às diferentes regiões. As empresas de produção de sementes e instituições de pesquisa vêm colocando no mercado, a cada ano, novas cultivares com acentuadas diferenças quanto aos caracteres agronômicos desejáveis, tolerância a estresses abióticos e bióticos, estabilidade e adaptabilidade (Duarte \& Paterniani, 1997). A avaliação regionalizada dessas cultivares permitiu que fossem conhecidos de maneira mais ampla os diferentes ambientes onde cada 
variedade teve melhor desempenho, cuja agregação de informações proporcionou destacadas vantagens para as diferentes regiões produtoras (Duarte \& Paterniani, 1997, 1999).

\subsection{Aspectos de distribuição, bioecologia e importância econômica de Spodoptera frugiperda (J.E. Smith, 1797)}

Trabalhos de revisão bibliográfica envolvendo os diversos aspectos da lagarta-do-cartucho $S$. frugiperda foram realizados por Andrews (1988), Ashley et al. (1989) e Isenhour \& Davis (1999).

Wiseman (1999) considerou S. frugiperda, dentre a gama de pragas da cultura do milho, como possivelmente a mais destrutiva.

Wiseman et al. (1966) consideram-na como a mais importante entre as pragas do milho nas Américas, com ampla distribuição.

Lopez-Edwards et al. (1999) estudaram cinco populações de $S$. frugiperda no México, avaliando parâmetros biológicos, controles químico e biológico e capacidade reprodutiva. Os autores encontraram diferenças entre as populações para os parâmetros estudados e sugeriram a existência de dois biótipos, dados principalmente em função do isolamento geográfico proporcionado pela Sierra Madre Oriental, determinando a distribuição da praga naquela região da América.

No Brasil, Leiderman \& Sauer (1953) destacaram a lagarta-do-cartucho entre as principais pragas da cultura do milho, considerando-a extremamente polífaga e com vários hospedeiros. Além do milho, pode atacar a alfafa, algodão, amendoim, arroz, aveia, batata, batata-doce, cana-de-açúcar, hortaliças, trigo e soja, sendo mais encontrada em gramíneas. Segundo levantamento desses autores, já na década de 20 eram relatados em diversos estados brasileiros danos severos provocados por essa lagarta, também conhecida por "lagarta-dos-milharais" ou "lagarta-militar" ou ainda "curuquerêdo-milho". Atualmente, é encontrada em praticamente todos os estados, 
favorecida pelas condições climáticas e pela disponibilidade e diversificação de plantas hospedeiras o ano todo (Cruz, 1995), tendo sido observado significativo aumento da sua população nas diversas regiões (Cruz, 1999). Em 1998, foram gastos no Brasil aproximadamente 60 milhões de dólares com inseticidas na cultura do milho e cerca de $40 \%$ desse montante foi utilizado para controle da lagarta-do-cartucho (Omoto et al., 2000).

Wiseman et al. (1983) comentaram a importância da praga para a economia americana sendo estimadas perdas de milhares de dólares anualmente face aos danos provocados pela praga, principalmente em gramíneas.

Suscetíveis em praticamente todas as fases de desenvolvimento, as plantas de milho ficam prejudicadas pela destruição do cartucho, reduzindo a área fotossintética e comprometendo a produção. A lagarta-do-cartucho pode ainda atacar a base da espiga, destruindo grãos ou abrindo caminho para microrganismos, e até mesmo provocando a queda da espiga (Cruz, 1999).

O efeito de $S$. frugiperda na produção de milho foi estudado por diversos autores. Carvalho (1970), trabalhando com diversos genótipos, estimou a redução na produtividade entre $15 \%$ e $34 \%$, dependendo da fase de desenvolvimento da planta, sendo que, aos 49 dias após o plantio, observou redução de $30 \%$.

Cruz \& Turpin (1982) também avaliaram os danos da praga em diferentes estádios de desenvolvimento e concluíram que o estádio mais suscetível à lagarta-do-cartucho foi o de 8 a 10 folhas, ou seja, em torno de 40 dias após o plantio, coincidindo com as observações de Carvalho (1970). Os autores encontraram redução no rendimento da produção da ordem de 18,7\%. Concluíram ainda que danos foliares severos não levam necessariamente, a uma perda de produção já que infestações realizadas no estádio de 4 a 6 folhas, embora tenham resultado em maior índice de dano foliar (nota 4,5 numa escala de 1 a 5) proporcionaram baixo percentual na redução do rendimento (6,6\%), em relação aos demais tratamentos. Em 1983, Cruz \& Turpin 
apresentaram dados de um estudo que avaliou o impacto dessa praga no rendimento de grãos de milho sob diferentes níveis de infestação. Infestando plantas no estádio de 8 a 10 folhas, obtiveram redução de $17 \%$ no rendimento para infestações em $20 \%$ a $100 \%$ das plantas, concluindo que a redução nos rendimentos foi diretamente proporcional aos danos (maior dano promove menor rendimento) e que o potencial de redução no rendimento pode ser mensurado na fase de "cartucho".

Cruz et al. (1996), num estudo comparativo entre o efeito de níveis de saturação de alumínio no solo e os danos causados pela $S$. frugiperda, entenderam que independentemente dos genótipos resistentes ou suscetíveis utilizados em relação aos níveis de saturação de alumínio ou da disponibilidade de nutrientes, os danos causados pela lagarta promoveram redução no rendimento em torno de $18 \%$.

Entretanto, deve-se considerar que o percentual de redução na produtividade de grãos de milho, em função dos danos auferidos pela lagartado-cartucho, é também afetado por vários fatores, como o estádio de desenvolvimento onde a planta é infestada, as cultivares utilizadas, os locais e as épocas de cultivo, os sistemas de produção e as práticas agronômicas adotadas.

\subsection{Metodologias de infestação e avaliação para detecção de genótipos resistentes}

Como método de controle de pragas, o programa de resistência de plantas a insetos requer planejamento adequado para que possa promover os resultados satisfatórios no manejo integrado de pragas.

Entre os pré-requisitos para o sucesso nos programas de resistência de plantas a insetos estão os métodos de infestação e avaliação dos experimentos. 
Wiseman \& Davis (1979) fizeram uma revisão da história e do estado da arte de resistência de plantas à lagarta-do-cartucho, destacando a importância da uniformidade da infestação, seja ela natural ou artificial. As populações naturais da praga seriam usadas em screenings para identificação da resistência e havendo forte pressão de seleção elas favoreceriam a detecção da não-preferência. Infestações artificiais com insetos produzidos em massa, entretanto, seriam mais eficientes e práticas, principalmente quando existe possibilidade de se transportar o material até os locais de experimentação. Nishikawa (1999) destacou a necessidade de treinamento pessoal e laboratório de apoio na utilização dessa técnica. Em geral, as infestações artificiais podem ser efetuadas pelos métodos de pincel, massas de ovos ou por meio de dispensadores de larvas conhecidos como "bazucas". Esses instrumentos vêm sendo amplamente utilizados pela facilidade de uso e uniformidade de infestação, sendo possível controlar com eficiência o número de lagartas liberadas por planta. Experimentos de laboratório complementam o trabalho de campo, sendo essenciais na investigação dos mecanismos e das bases da resistência. Quanto aos métodos de avaliação, Wiseman \& Davis (1979) descreveram ainda as diferentes escalas de notas utilizadas nos experimentos de campo e em casa de vegetação ( 0 a 3; 0 a 5; 1 a 10; 0 a 9; medidas percentuais etc.), destacando que a escala que utiliza dez níveis ( 0 a 9 ) tem sido a mais usada, bem como diversos parâmetros biológicos dos insetos têm sido utilizados na mensuração dos experimentos de laboratório.

Leuck (1972), avaliando resistência induzida em milheto, testou variações de fertilizantes fazendo testes em laboratório e em casa de vegetação. Utilizando escala de 1 a 9 , atribuiu essas notas em função do percentual de danos (nota $1=10 \%$, nota $2=20 \%$ etc.) em folhas contidas em caixas sob infestação de 5.000 lagartas. Para detectar tolerância, utilizou vasos em casa de vegetação infestando os seedlings com 6 lagartas por vaso e avaliou o efeito medindo as diferenças de peso e vigor entre folhas infestadas e não infestadas. 
Mesmo sendo utilizado o mesmo número de níveis nas escalas de notas, a descrição dentro de cada nota pode sofrer pequenas adaptações de acordo com a interpretação ou necessidade de cada autor.

Williams et al. (1978), avaliando cruzamentos dialélicos para resistência a $S$. frugiperda sob infestação natural, realizaram dois ensaios, sendo que no primeiro usaram a escala de 0 a 9 utilizada por Wiseman et al. (1966) em avaliação de seedlings, porém modificando os critérios nas notas de 3 a 8 . Já no segundo ensaio, avaliaram as plantas no estádio V6-V8, com escala de 1 a 3 , devido à forte infestação natural da praga ocorrida no início da cultura.

Carvalho (1970) utilizou escala de 0 a 5 para determinar o efeito de danos na produção, realizando ensaios de campo em regiões com forte pressão de seleção.

Williams et al. (1983), usando a técnica de infestação artificial para avaliar a supressão de sobrevivência e crescimento de $S$. frugiperda em genótipos resistentes, adaptaram a escala de 0 a 9 usada por Williams et al. (1978), alterando algumas descrições em razão da uniformidade dada pela infestação artificial.

Davis et al. (1992) modificaram uma escala de 0 a 9 para discriminação de genótipos em experimentos com infestações artificiais, fazendo alterações nas descrições para a avaliação aos 7 dias, diferenciando-as das avaliações feitas aos 14 dias após a infestação. Realizando duas avaliações e diferenciando descrições, procuraram minimizar o efeito de notas mais altas em genótipos resistentes devido à migração de lagartas de plantas suscetíveis vizinhas. Nishikawa (1999) utilizou essa metodologia, corroborando a opinião desses autores.

Wiseman \& Widstrom (1980) compararam vários métodos de infestação, variando também o número de plantas infestadas e o número de lagartas por planta. Realizaram a infestação em plantas no estádio de 10 a 12 folhas e uma segunda infestação três dias depois. Compararam os métodos de pincel (10 lagartas por planta), de massa de ovos (entre 50 e 75 ovos) e de "bazuca" (10 
lagartas por planta) e mediram os danos em 10 plantas, após 15 dias da infestação, usando a escala de 0 a 9 . Em outro ensaio, realizaram a infestação com "bazuca", variando o número de lagartas por planta em 0, 10, 20 e 40 lagartas e infestando todas as plantas da linha, a cada duas plantas e a cada três plantas. Os autores concluíram que o método mais eficiente de infestação foi o da "bazuca", devendo-se infestar todas as plantas das parcelas e realizar duas aplicações para garantir a infestação, devido ao escape de lagartas. Verificaram ainda que as plantas foram mais bem infestadas nas parcelas de 20 e 40 lagartas por planta. Essa recomendação vem sendo praticada por diversos autores em muitos trabalhos, com modificações, por vezes, quanto ao estádio de desenvolvimento da planta a ser infestado e quanto ao número de lagartas dispensadas no cartucho, prevalecendo duas aplicações com 15 lagartas na maioria dos casos (Abel et al., 2000; Alvarez, 2001; $\mathrm{Ng}$ et al., 1985; Nishikawa, 1999; Videla et al., 1992; Widstrom et al., 1992; Williams et al., 1983, 1990; Wiseman et al., 1981, 1983, 1996; Yang et al., 1991).

Pesquisas para discriminação de genótipos resistentes ou identificação dos mecanismos de resistência também têm sido conduzidas sob infestação natural (Lara et al., 1984; Tozetti et al., 1995). Widstrom et al. (1992) trabalharam em cinco gerações com seleção recorrente para resistência à lagarta-do-cartucho e usaram infestação artificial somente quando não se verificou suficiente infestação natural no campo.

Cruz \& Turpin (1982) utilizaram massas de ovos para fazer infestação, alfinetando-as na nervura da folha principal em cada estádio de desenvolvimento testado. Segundo os autores, utilizando ovos em vez de lagartas, teriam maior aproximação com o método natural de infestação.

Wiseman \& Davis (1990) ressaltaram que o avanço nas técnicas de criação massal, infestação e avaliação ajudaram a desenvolver as pesquisas em busca de fontes de resistência a $S$. frugiperda. Os autores argumentaram que enquanto uma cultivar resistente está sendo desenvolvida, o mecanismo da 
resistência dever ser determinado e, se possível, as bases da resistência entendidas.

Entretanto, a relação inseto-planta é dinâmica, resultado de um longo e contínuo processo evolutivo, em que a cada adaptação da planta tende a ocorrer uma contra-adaptação do inseto. Fatores de resistência das plantas tendem a exercer uma pressão de seleção sobre as pragas, as quais buscam neutralizar esses fatores, passando a exercer a pressão de seleção sobre as plantas; estas, por sua vez, passam a desenvolver novos mecanismos de defesa (Vendramim \& Nishikawa, 2001). Segundo esses autores, os meios pelos quais uma planta apresenta resistência a uma praga envolvem alterações no comportamento e na biologia do inseto ou então ocorre reação da planta que não afeta o inseto.

O entendimento desses mecanismos é de grande utilidade nos programas de melhoramento de plantas, orientando as ações na busca das fontes de resistência aos insetos.

Um dos alvos nos estudos de resistência de plantas de milho à lagartado-cartucho é a determinação do estádio mais suscetível no qual devem ser realizadas as infestações em campo ou para estudos em laboratório.

Williams et al. (1978), avaliando cruzamentos dialélicos em experimentos em condições de campo, sob infestação natural, anteciparam a época de avaliação para o estádio de 6 a 8 folhas devido à forte pressão de seleção e aos significativos danos ocorridos nessa fase da cultura.

Williams et al. (1983), estudando as correlações entre genótipos resistentes e suscetíveis e os estádios de desenvolvimento da planta, avaliaram seis genótipos, em dois locais e em duas épocas, com infestações nos estádios de 5 e 10 folhas e concluíram que houve alta correlação entre os danos e o número de lagartas mortas. Houve também redução do peso larval tanto no estádio de 5 quanto no de 10 folhas, ou seja, independentemente da base da resistência, ela estava presente nos dois estádios de crescimento. 
Cruz \& Turpin (1982), estudando o efeito de danos em diferentes estádios de crescimento, realizaram infestações em plantas com 4 a 6,8 a 10 e 12 a 14 folhas e concluíram que o estádio mais suscetível foi o de 8 a 10 folhas, ocasionando redução no rendimento de $18,7 \%$, devido principalmente ao decréscimo no número de grãos.

Crócomo \& Parra (1985) compararam o consumo e utilização de milho, trigo e sorgo por $S$. frugiperda e para a realização dos experimentos utilizaram folhas a partir do $30^{\circ}$ dia de germinação, coincidindo com o estádio de V6-V8 de desenvolvimento, no caso do milho.

$\mathrm{Ng}$ et al. (1985) utilizaram plantas com 8 a 10 folhas para avaliar o efeito de genótipos na sobrevivência, crescimento e reprodução da lagarta-docartucho e fizeram testes preliminares para saber qual parte da folha de milho usar nos testes de laboratório. Utilizaram somente a região verde-amarela da folha, já que $99 \%$ das lagartas se alimentavam nessa região.

Williams \& Buckley (1992), avaliando o crescimento de lagartas em genótipos resistentes e suscetíveis, utilizaram o estádio V6-V8 e avaliaram que as lagartas atacam as plantas de milho em todas as fases de desenvolvimento, porém essas são mais vulneráveis nas primeiras fases de cartucho.

Williams et al. (1990) registraram o genótipo Mp708 de milho como resistente a $S$. frugiperda e nos ensaios de campo realizaram a infestação artificial na fase de 6 folhas denominando-a "cartucho primário". Williams et al. (1990) consideraram a fase de 8 folhas como sendo de "cartucho médio" para estudar o efeito de genótipos resistentes a $S$. frugiperda e a $D$. grandiosella. Yang et al. (1991) usaram o estádio de 10 a 12 folhas ("cartucho bem desenvolvido") para avaliar a atividade de lipídios cuticulares na região verdeamarela das folhas. Essa idade de planta foi também utilizada por Widstrom et al. (1992) em testes de seleção recorrente visando estudar a resistência à lagarta-do-cartucho.

Um amplo estudo realizado por 2 anos, avaliando o efeito do estádio de desenvolvimento de plantas resistentes e suscetíveis no crescimento e 
mortalidade da lagarta-do-cartucho foi realizado por Videla et al. (1992). Os autores utilizaram genótipos com reconhecida resistência e suscetibilidade em V8 e os avaliaram nos estádios V3, V6 (primário), V8 (intermediário), V12 (adiantado) e V14 (pré-floração). Concluíram que os materiais resistentes em V8 também o foram nos demais estádios, à exceção de V14.

Tozetti et al. (1995), avaliando progênies de "Composto Dentado" em condições de campo na safrinha, avaliaram os experimentos para o parâmetro de resistência à lagarta-do-cartucho aos 44 dias após o plantio, período coincidente ao estádio de 10 folhas.

Wiseman et al. (1996) estudaram o comportamento da população de milho FAWCC(C5) infestando plantas nos estádios de 8 e 12 folhas e concluíram que os maiores danos foram em $\mathrm{V} 8$ em relação a $\mathrm{V} 12$ em todos os tratamentos.

Paralelamente, nos últimos anos, têm-se intensificado esforços para determinar os mecanismos e as bases físico-químicas da resistência das plantas. Em geral, grande parte dos materiais recomendados como resistentes a S. frugiperda tiveram origem nas populações Antigua, grupos 1 e 2 e República Dominicana 1, germoplasma exótico do Caribe (Davis et al., 1999; Wiseman \& Davis, 1979).

Wiseman \& Davis (1990) compilaram trabalhos realizados com plantas de milho e sorgo visando avaliar a resistência aos principais lepidópteros desfolhadores dessas culturas, citando os mecanismos e as fontes de resistência relacionadas.

Wiseman et al. (1981) avaliaram o efeito do genótipo resistente Antigua 2D-118 sobre a alimentação e sobrevivência de $S$. frugiperda e observaram que o mesmo manteve a resistência durante os 3 anos em que foram conduzidos os estudos, encontrando como principal mecanismo de resistência o de nãopreferência.

Wiseman et al. (1983) avaliaram a densidade e a movimentação da lagarta-do-cartucho como indicadores de não-preferência e testaram os 
genótipos resistentes Antigua 2D-118, MpSWCB-4 e Mp496 x MpSWCB-1 e o suscetível Cacahuacintle X's. Um significativo número de lagartas saiu do Antigua 2D-118 e foi para o MpSWCB-4 e/ou para o genótipo suscetível. Os autores corroboraram então os dados de Wiseman et al. (1981) quanto ao mecanismo de não-preferência presente no Antigua 2D-118 e concluíram que o genótipo MpSWCB-4 apresentou maior intensidade no mecanismo de antibiose em relação ao de não-preferência.

Wiseman \& Widstrom (1986) avaliaram a resistência do estilo-estigma da raça centro-americana Zapalote Chico, resistente a $S$. frugiperda. Os autores observaram a presença de fatores antibióticos nesse material com alterações em diversos parâmetros biológicos. O genótipo também apresentou nãopreferência em relação ao material suscetível.

Williams et al. (1990) realizaram testes de laboratório com materiais resistentes e suscetíveis utilizando tecidos foliares liofilizados, comparando-os com testes de discriminação em campo. Os autores concluíram que houve alta correlação tanto para os genótipos resistentes quanto para os suscetíveis, indicando que os bioensaios de laboratório com tecidos liofilizados podem ser um método adicional para o estudo dos mecanismos de resistência, além da vantagem de serem controlados os efeitos abióticos e bióticos que normalmente ocorrem no campo.

A superfície da planta com a qual o inseto entra primeiramente em contato desempenha importante papel na interação inseto-planta. Yang et al. (1991) estudaram o papel dos lipídios cuticulares da região verde-amarela de plantas resistentes e suscetíveis e concluíram que esses lipídios agem na resistência da lagarta-do-cartucho. O genótipo MpSWCB-4, por exemplo, apresentou alto grau de resistência nas avaliações de campo. No laboratório, lagartas alimentadas com esse material em dieta artificial, mas sem a presença dos lipídios cuticulares, apresentaram desenvolvimento máximo.

Em trabalho complementar, Yang et al. (1993) avaliaram a composição dos lipídios cuticulares nas folhas superiores e inferiores das plantas de milho. 
Folhas superiores tinham maior concentração de n-alcanos, que são relatados como deterrentes de alimentação, enquanto que folhas inferiores apresentaram maiores índices de componentes graxos, que são estimulantes de alimentação. Os autores observaram que lagartas pesaram mais e se desenvolveram mais rapidamente quando alimentadas com dieta contendo o extrato de folhas de onde os lipídios tinham sido retirados, em relação àquelas onde estavam presentes. Entretanto, quando lagartas foram alimentadas com dieta contendo os componentes isoladamente, não houve inibição no crescimento, indicando que a ação dos lipídios cuticulares pode estar associada a outros componentes, agindo de forma sinérgica.

Wiseman et al. (1996) compararam a resistência do genótipo FAWCC(C5) com o resistente MpSWCB-4 e um suscetível, em condições de campo. Os autores concluíram que antibiose (baixo peso larval) e nãopreferência (poucas lagartas nas plantas) são mecanismos presentes nas duas populações resistentes.

Silveira et al. (1998) realizaram teste de livre escolha com lagartas recém-eclodidas e encontraram não-preferência nos genótipos Zapalote Chico e Mp707. Em teste de consumo foliar, esses mesmos genótipos foram os menos consumidos, confirmando o mecanismo de não-preferência.

Davis et al. (1999) usaram material fresco e liofilizado de três regiões do cartucho determinadas pelas porções verde, verde-amarela e amarelo-branca de genótipos resistentes e suscetíveis. Verificaram alta sobrevivência em todos os tratamentos, indicando ausência de antibiose. Entretanto, lagartas alimentadas com folhas frescas de genótipo resistente apresentaram maior peso na região amarelo-branca e menor na região verde-amarela. O menor peso proporcionado pela região verde-amarela também foi observado com tecidos foliares liofilizados. Os autores concluíram que existem fatores de resistência na região verde-amarela do cartucho e que eles podem ser diferentes em presença e intensidade em genótipos resistentes e suscetíveis. 
Destacaram ainda a importância de se estudar a região do cartucho e a sua utilização em testes de laboratório.

Wiseman (1999) avaliou o efeito cumulativo da antibiose em cinco parâmetros biológicos da lagarta-do-cartucho usando estilo-estigmas do genótipo resistente Zapalote Chico, incorporados em dietas artificiais, em doses baixa $(12,5 \mathrm{mg})$, intermediária $(25 \mathrm{mg})$ e alta $(50 \mathrm{mg})$. Após cinco gerações, verificou que mesmo os baixos níveis de resistência considerados no ensaio atuaram nos parâmetros testados. Considerou ainda que $S$. frugiperda alimentada nos vários níveis de resistência presentes no cabelo de milho não conseguiu ajustar o estresse causado pela resistência, mesmo depois de cinco gerações.

Viana \& Potenza (2000) estudaram os mecanismos de antibiose e nãopreferência em cultivares de milho selecionados como resistentes a $S$. frugiperda em testes de laboratório e casa de vegetação. Os autores observaram que houve, primeiramente, efeito da planta sobre o comportamento do inseto, o que diferiu da adequação de cada genótipo ao balanço nutricional da lagarta, visto que os genótipos mais atrativos e mais consumidos foram os menos adequados a sua biologia.

Segundo Chang et al. (2000), a causa da inibição do crescimento larval deve estar ligada a alguma diferença bioquímica entre os genótipos resistentes e suscetíveis, contribuindo para uma resposta diferenciada na alimentação. Assim, realizaram experimentos em laboratório avaliando índices de consumo e utilização de alimento, utilizando tecidos liofilizados das regiões verde, verdeamarela e amarela de cartuchos dos genótipos resistente e suscetível. Maior redução de crescimento, da ordem de 20 vezes, foi observada no genótipo resistente em relação ao suscetível, quando utilizada a região verde-amarela do cartucho. Utilizando anticorpos monoclonais para a cisteína proteinase, os autores verificaram que no genótipo resistente a enzima foi ausente na região amarela, abundante na região verde-amarela, baixa na região verde e não foi detectada no genótipo suscetível. Dessa forma, correlacionaram a região verde- 
amarela com a redução de peso das lagartas, de acordo com a presença de enzimas contidas em grande quantidade naquela região.

\subsection{Disponibilização e recomendação de genótipos resistentes}

Barriga \& Vencovsky (1973) enfatizaram a importância das informações genéticas sobre caracteres estudados em melhoramento de plantas para que seja possível selecionar populações-base com genes que confiram caracteres desejáveis ao melhoramento.

Programas de melhoramento de plantas visando resistência a insetos necessitam de planejamento adequado, visto que envolvem diversas etapas de execução (Vendramim \& Nishikawa, 2001).

Quando bem planejado, um banco de germoplasma resistente a insetos é importante ferramenta para o sucesso do manejo integrado de pragas. Entretanto, os materiais só podem ser disponibilizados e recomendados após terem sido também avaliados quanto aos seus critérios agronômicos, requerendo-se portanto um trabalho conjunto de especialistas de diferentes áreas. É fundamental também que os usuários sejam informados dos mecanismos envolvidos para que possam fazer uso adequado dos materiais no manejo. Programas de melhoramento visando resistência a insetos são longos; estima-se que para cada dólar investido em programas de resistência, exista retorno aproximado de 300 dólares, justificando a continuidade de pesquisas em busca de fontes de resistência (Wiseman \& Davis, 1990).

Muitos trabalhos de resistência têm sido desenvolvidos principalmente nos Estados Unidos. Segundo Wiseman \& Davis (1990), um total de 31 cultivares de milho foram registrados e disponibilizados para uso público no sudeste do Estados Unidos, sendo 12 resistentes a $H$. zea, 10 resistentes a $S$. frugiperda e 9 resistentes a $D$. grandiosella.

Wiseman et al. (1967) avaliaram 81 linhagens de germoplasma latino americano de milho, provenientes do México, América Central e Caribe. Os 
autores destacaram a linhagem Antigua como sendo portadora de alto grau de resistência à lagarta-do-cartucho.

Segundo Wiseman \& Davis (1979), o primeiro material com reconhecida resistência à lagarta-do-cartucho foi o Mp496, disponibilizado por Scott et al., em 1977 (registrado como linhagem parental por Scott \& Davis, 1981a) com origem em Antigua 2D e obtido sob fortíssima pressão de seleção da praga. Segundo os autores, até aquele momento a maioria dos materiais resistentes eram provenientes da linhagem Antigua.

Pears \& Saunders (1981), citados por Silveira (1994), estudaram no México as populações tropicais Tuxpeño 1 e Mezcla Amarilla. Alvarez (2001) relatou que Smith (1982) obteve moderados níveis de resistência no germoplasma Tuxpeño, identificando principalmente o mecanismo de tolerância.

Scott \& Davis (1981b) lançaram a população MpSWCB-4 obtida por seleção recorrente de populações de grupo Antigua 1 e 2 e República Dominicana 1, apresentando boa resistência a S. frugiperda.

Outros materiais registrados como resistentes à lagarta-do-cartucho também tiveram origem em populações tropicais, como: Mp701 (originado de Antigua grupos 1 e 2 e República Dominicana 1) e Mp702 (originado de República Dominicana 1) (Scott et al., 1982); Mp704 (proveniente de República Dominicana 1) e Mp496 (Williams \& Davis, 1982) e as populações Mp705, Mp706 e Mp707 desenvolvidas a partir de seleção individual de MpSWCB-4 (Williams \& Davis, 1984).

Williams et al. (1990) disponibilizaram o germoplasma Mp708 desenvolvido a partir de seleção individual e de cruzamento de Mp704 x Tuxpeño-601 por oito gerações, com resistência a $S$. frugiperda e $D$. grandiosella.

Entre as cinco populações registradas por York (1991) com resistência a D. grandiosella e O. nubilalis, o autor destacou o material "Ark. Corn Borer Comp. \#3" como resistente também a S. frugiperda. Essa população foi obtida a 
partir dos cruzamentos entre as populações Mp701, Mp702, Mp704, Mp705, Mp706 e Mp707.

Viana \& Silva (1994) disponibilizaram a população CMS14 a partir de testes de campo, sob infestação artificial, o qual além de resistência à lagartado-cartucho apresenta também outras características agronômicas desejáveis. Guimarães \& Viana (1994) desenvolveram a população CMS23 a partir de 23 progênies $S_{2}$ selecionadas para resistência à lagarta-do-cartucho a partir da população original (Antigua $x$ República Dominicana) e cinco linhagens endogâmicas selecionadas para produtividade e interesse agronômico. Tanto CMS14 quanto CMS23 têm sido utilizadas em estudos de análise genética de populações de milho visando resistência à lagarta-do-cartucho (Alvarez, 2001; Nishikawa, 1999).

Widstrom et al. (1992) realizaram seleção recorrente com o milho sintético exótico FAW-CC para avaliar as variações genéticas, a herdabilidade e o ganho genético depois de 5 gerações (5 ciclos de seleção). Os autores obtiveram uma resposta de 0,31 unidades de redução de dano por ciclo, indicando significante efeito aditivo e processo de seleção satisfatório, mostrando que a população FAW-CC é uma fonte de resistência à lagarta-docartucho com níveis de intermediário para alto.

Wiseman et al. (1996) avaliaram o comportamento da população FAWCC(C5) - quinto ciclo de seleção - encontrando tanto antibiose quanto não-preferência nessa população.

Abel et al. (2000) avaliaram linhagens de milho proveniente de retrocruzamento de acessos de milho do Peru, resistentes a $O$. nubilalis. Foram testadas 15 linhagens, avaliando-se a resistência das mesmas às quatro mais importantes pragas do milho $(H$. zea, $S$. frugiperda, $D$. grandiosella e $D$. saccharalis). Os autores encontraram nas linhagens 100-R-3 e 116-B-10 o mesmo nível de resistência a $S$. frugiperda observado na testemunha resistente FAWCC-C5. Nesse caso, ambos os parentais recorrentes foram suscetíveis, indicando que o gene que confere resistência vem do doador parental peruano. 
A linhagem 116-B-10 apresentou também resistência a $D$. grandiosella. Os autores salientaram ser possível que a base de resistência fosse diferente, mas que os genes que conferem resistência múltipla deveriam estar num mesmo locus gênico, enfatizando a necessidade de estudos sobre a herança e as bases da resistência.

No Brasil, pesquisas também vêm sendo conduzidas para identificação de fontes de resistência a $S$. frugiperda.

Carvalho (1970) estudou um germoplasma de 60 e 22 unidades, em dois ensaios, formado por raças, híbridos e variedades. Entre as raças, confirmou para a região de Piracicaba/SP, a resistência da raça Antigua 2D à lagarta-docartucho. As variedades, de modo geral, apresentaram-se com "suscetibilidade moderada" e os híbridos comportaram-se como mais resistentes, não aparecendo entre o grupo dos mais suscetíveis.

Lara et al. (1984) avaliaram 42 variedades de milho visando resistência à lagarta-do-cartucho e à lagarta-da-espiga. Para danos de $S$. frugiperda, os dados demostraram comportamento diferenciado entre as variedades, porém, eles não foram conclusivos.

Tozetti et al. (1995) estudaram 100 progênies de híbridos interpopulacionais obtidos de cruzamentos entre "Composto Dentado" e "Composto Flint" para condições de safrinha. Foram avaliados caracteres agronômicos e resistência à lagarta-do-cartucho. Os autores destacaram a utilização do método de melhoramento de populações por meio de seleção recorrente, a qual garantiu progressos gradativos e cumulativos. Para a característica desejada de resistência à lagarta-do-cartucho, houve ganho genético (para uma intensidade de seleção de 10\%), indicando variabilidade suficiente para utilização dos materiais em melhoramento genético.

Nishikawa (1999) trabalhou em dois locais (Rio Verde/GO e Piracicaba/SP), com populações melhoradas para resistência à lagarta-docartucho (CMS14C, CMS23 e BR 5026). Utilizou cruzamentos topcrosses entre linhagens $S_{2}$ e a população original. $O$ autor considerou que os resultados 
obtidos caracterizaram esses genótipos como boas fontes de resistência para a lagarta-do-cartucho agregados a outros caracteres produtivos desejáveis.

Alvarez (2001) avaliou, por meio de cruzamento dialélico, populações pertencentes ao germosplasma brasileiro e também populações exóticas e semi-exóticas de diferentes origens, visando avaliar a resistência à lagarta-docartucho e outros caracteres agronômicos desejáveis. Em seu trabalho, os resultados mostraram a viabilidade da implementação de programas de seleção recorrente intra e interpopulacional, em relação à lagarta-do-cartucho. Também foram encontrados materiais com boa performance, per se e em cruzamentos, com possibilidade de incorporação nos programas de melhoramento.

Estudos em laboratório têm sido conduzidos com o objetivo de se determinar o efeito de genótipos resistentes sobre a biologia de $S$. frugiperda.

Melo \& Silva (1987) identificaram em lagartas alimentadas com o genótipo AG-28, alterações nos parâmetros larvais como aumento no período larval, proporcionando maior número de ínstares, maior comprimento e maior peso corporal.

Vendramim \& Fancelli (1988) observaram efeitos negativos na duração da fase larval, no peso de lagartas ( $8^{\circ} \mathrm{dia}$ ) e de pupas e na viabilidade de ovo, lagarta e pupa, com os genótipos Zapalote Chico e Cateto Palha Roxa.

Silveira et al. (1997) estudaram a biologia de S. frugiperda comparando cinco linhagens Mp (Mississipi, Estados Unidos), cinco linhagens IAC (Instituto Agronômico de Campinas) e a raça Zapalote Chico. Dentro das linhagens IAC, os autores estudaram os genes $\mathrm{B}$ e $\mathrm{PI}$, relacionados à produção de fitoalexinas por $\mathrm{PI}$, mas que só é manifestada quando este é dominante e ligado à presença de outro gene dominante, no caso, o $\mathrm{B}$. Os resultados mostraram pesos larvais significativamente menores nos genótipos com BPI (IAC103-BPI e IAC701-BPI) em relação aos materiais sem esse genes (IAC103-N e IAC701-N). A viabilidade larval também foi afetada, sendo o IAC701-BPI o que apresentou maior mortalidade em relação ao IAC701 N. Os autores confirmaram ainda o caráter de resistência dos genes BPI quanto ao peso pupal para IAC103-BPI em 
relação à IAC103-N, os quais se situaram em extremos opostos nesse parâmetro. De modo geral, quando comparadas todas as linhagens estudadas, os genes B e PI conferiram resistência moderada a S. frugiperda.

Viana \& Potenza (2000) estudaram os mecanismos de resistência em genótipos de milho (CMS-14C, CMS-23, CMS-24 e BR-201), com resistência para a lagarta-do-cartucho estudando vários parâmetros biológicos. CMS-14C apresentou antibiose e não-preferência para oviposição. O genótipo BR-201 apresentou não-preferência para alimentação, sendo que esse material já está comercialmente consolidado.

Viana et al. (2002) estudaram a ocorrência de antibiose em 51 genótipos de milho selecionados a partir de dois alelos (CMS23 e MIRT). Dos cruzamentos dialélicos entre as linhagens dessas populações, alguns dos genótipos afetaram negativamente a biologia de $S$. frugiperda, tanto do grupo de CMS-23 quanto do grupo MIRT. 


\section{MATERIAL E MÉTODOS}

\subsection{Genótipos de milho}

Foram utilizados, tanto nos experimentos de campo quanto nos de laboratório, 12 genótipos de milho, entre híbridos simples, híbridos duplos, híbridos triplos e variedades (Tabela 1).

Tabela 1. Genótipos de milho utilizados nos experimentos com Spodoptera frugiperda (J.E. Smith, 1797), em condições de campo e de laboratório.

\begin{tabular}{lccccc}
\hline Genótipo & Tipo $^{(1)}$ & Endosperma & Cor do Grão & Ciclo & Uso \\
\hline IAC-21 & HS & Semi-duro & Alaranjado & Precoce & Grão \\
Z 8486 & HS & Semi-duro & Alaranjado & Precoce & Grão \\
XL 212 & HS & Dentado & Amarelo-laranja & Normal & Grão \\
Dina 766 & HSm & Semi-duro & Alaranjado & Superprecoce & Grão \\
C 333 B & HSm & Semi-duro & Amarelo-laranja & Normal & Grão \\
Master & HT & Dentado & Amarelo & Normal & Grão \\
Exceler & HT & Semi-dentado & Alaranjado & Precoce & Grão \\
IAC-Vitória & $\mathrm{V}$ & Semi-duro & Alaranjado & Precoce & Grão \\
IAC-Pariquera & $\mathrm{V}$ & Dentado & Amarelo & Normal & Grão \\
CATI AL 30 & $\mathrm{V}$ & Semi-dentado & Alaranjado & Normal & Grão \\
Piranão VF1 & $\mathrm{V}$ & Semi-duro & Amarelo & Normal & Grão \\
AG 1051 & HD & Dentado & Amarelo & Normal & Milho verde \\
\hline (1) HS = híbrido simples; HSm = híbrido simples modificado; HT = híbrido triplo; V = variedade; \\
HD = híbrido duplo.
\end{tabular}


As sementes dos genótipos Z 8486, Master, Exceler, C 333 B, Dina 766, XL 212, CATI AL 30 e AG 1051 foram fornecidas pelo Pólo Regional de Desenvolvimento Tecnológico do Agronegócio do Médio Paranapanema - IAC - Apta, que coordena os ensaios regionais de avaliação de cultivares de milho do Estado de São Paulo. Essas sementes foram obtidas dos mesmos lotes utilizados nos ensaios regionais, retiradas de embalagens de $20 \mathrm{~kg}$, que foram amostradas diretamente nos pontos de venda.

Os genótipos IAC-21, IAC-Vitória, IAC-Pariquera e Piranão VF-1 foram fornecidos pelo Centro de Análise e Pesquisa Tecnológica do Agronegócio dos Grãos e Fibras do Instituto Agronômico de Campinas - Apta.

O genótipo Piranão foi o padrão de suscetibilidade, já que é utilizado com esse fim em vários estudos de melhoramento genético de milho, visando resistência à lagarta-do-cartucho.

\subsection{Experimentos em condições de campo}

\subsubsection{Locais e épocas de cultivo}

Os experimentos em condições de campo foram realizados em municípios de três diferentes regiões (Centro, Médio Vale do Paranapanema e Norte) do Estado de São Paulo, selecionados a partir de sua importância nas respectivas regiões como produtores de milho na safra e/ou na safrinha (Tabela 2).

Na safrinha de 2000 em Florínea e Miguelópolis e na safrinha de 2001 em Guaíra, os experimentos não foram avaliados em razão da forte estiagem, o que diminuiu consideravelmente o estande, comprometendo a infestação natural pela lagarta-do-cartucho e, consequentemente, as avaliações.

Nas safras, procurou-se manter um curto intervalo de tempo entre os plantios, num período máximo de uma semana entre cada local. Nas safrinhas, a melhor época de semeadura foi considerada em função do regime de chuvas 
Tabela 2. Locais, épocas de cultivo, datas dos plantios e das avaliações (DAP) ${ }^{1}$ dos campos experimentais de S. frugiperda, sob infestação natural.

\begin{tabular}{|c|c|c|c|c|}
\hline REGIÕES & CENTRO & PARANAPANEMA & \multicolumn{2}{|c|}{ NORTE } \\
\hline LOCAIS & $\begin{array}{c}\text { CASA BRANCA } \\
21^{\circ} 46^{\prime} 29^{\prime \prime} \mathrm{S} \\
47^{\circ} 05^{\prime} 16^{\prime \prime} \mathrm{W} \\
\text { Altitude } 717 \mathrm{~m} \\
\text { Latossolo vermelho, } \\
\text { distroférrico, argiloso }\end{array}$ & $\begin{array}{c}\text { FLORÍNEA } \\
22^{\circ} 47^{\prime} 177^{\prime \prime} \mathrm{S} \\
50^{\circ} 32^{\prime} 44^{\prime \prime} \mathrm{W} \\
\text { Altitude } 420 \mathrm{~m} \\
\text { Nitossolo vermelho, } \\
\text { eutroférrico, argiloso }\end{array}$ & $\begin{array}{l}\text { MIGUELÓPOLIS } \\
20^{\circ} 10^{\prime} 15^{\prime \prime} \mathrm{S} \\
48^{\circ} 02^{\prime} 15^{\prime \prime} \mathrm{W} \\
\text { Altitude } 635 \mathrm{~m} \\
\text { Latossolo vermelho, } \\
\text { acriférrico, argiloso }\end{array}$ & $\begin{array}{c}\text { GUAÍRA } \\
20^{\circ} 19^{\prime} 03^{\prime \prime S} \\
48^{\circ} 18^{\prime} 48^{\prime \prime} \mathrm{W} \\
\text { Altitude } 490 \mathrm{~m} \\
\text { Latossolo vermelho, } \\
\text { acriférrico, argiloso }\end{array}$ \\
\hline $\begin{array}{c}\text { Safra 1999/2000 } \\
\text { Plantio } \\
1^{\text {a }} \text { avaliação } \\
2^{\text {a }} \text { avaliação }\end{array}$ & $\begin{array}{l}22 / 11 / 1999 \\
22 / 12 / 1999 \text { (30 DAP) } \\
06 / 01 / 2000 \text { (45 DAP) }\end{array}$ & $\begin{array}{l}\text { 17/12/1999 } \\
12 / 01 / 2000 \text { (26 DAP) } \\
28 / 01 / 2000 \text { (42 DAP) }\end{array}$ & $\begin{array}{l}\text { 18/11/1999 } \\
15 / 12 / 1999 \text { (27 DAP) } \\
04 / 01 / 2000 \text { (47 DAP) }\end{array}$ & ---------- \\
\hline $\begin{array}{l}\text { Safrinha } 2000 \\
\text { Plantio } \\
1^{\text {1a }} \text { avaliação } \\
2^{\text {a }} \text { avaliação }\end{array}$ & $\begin{array}{l}10 / 03 / 2000 \\
07 / 04 / 2000 \text { (28 DAP) } \\
20 / 04 / 2000 \text { (41 DAP) }\end{array}$ & --------- & --------- & --------- \\
\hline $\begin{array}{c}\text { Safra } 2000 / 2001 \\
\text { Plantio } \\
1^{\text {a }} \text { avaliação } \\
2^{2^{\mathrm{a}}} \text { avaliação }\end{array}$ & $\begin{array}{l}\text { 01/11/2000 } \\
\text { 04/12/2000 (33 DAP) } \\
20 / 12 / 2000 \text { (49 DAP) }\end{array}$ & $\begin{array}{l}10 / 11 / 2000 \\
11 / 12 / 2000 \text { (31 DAP) } \\
27 / 12 / 2000 \text { (47 DAP) }\end{array}$ & ---------- & $\begin{array}{l}17 / 11 / 2000 \\
18 / 12 / 2000 \text { (31 DAP) } \\
03 / 01 / 2001 \text { (47 DAP) }\end{array}$ \\
\hline $\begin{array}{c}\text { Safrinha } 2001 \\
\text { Plantio } \\
1^{\text {a }} \text { avaliação } \\
2^{\underline{a}} \text { avaliação }\end{array}$ & $\begin{array}{l}\text { 17/03/2001 } \\
\text { 18/04/2001( } 32 \text { DAP) } \\
10 / 05 / 2001 \text { (54 DAP) }\end{array}$ & $\begin{array}{l}\text { 15/03/2001 } \\
\text { 20/04/2001(36 DAP) } \\
\text { 04/05/2001(50 DAP) }\end{array}$ & -------- & --------- \\
\hline
\end{tabular}

${ }^{1} \mathrm{DAP}=$ Dias Após o Plantio.

$1^{\mathrm{a}}$ avaliação = plantas com 6 a 8 folhas; $2^{\underline{a}}$ avaliação = plantas com 10 a 12 folhas. 

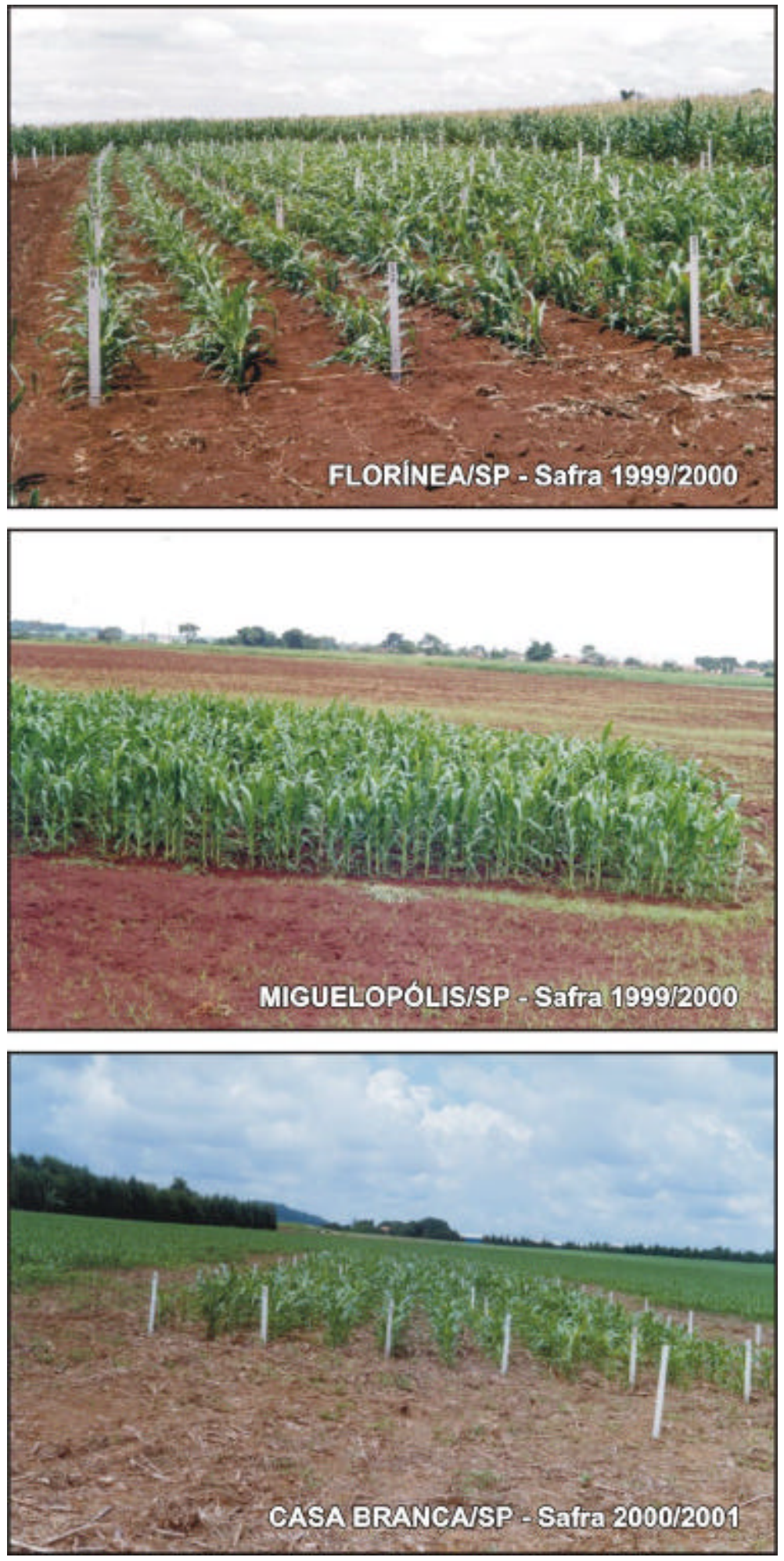

Figura 1 - Áreas experimentais em diferentes regiões do Estado de São Paulo, para avaliação do dano de $S$. frugiperda em genótipos de milho. 
para cada região, variando entre a segunda quinzena de fevereiro e a primeira quinzena de março.

\subsubsection{Delineamento experimental}

Os experimentos foram realizados em áreas cedidas por agricultores. As áreas experimentais ficaram separadas das áreas plantadas dos agricultores por pelo menos $4 \mathrm{~m}$ de distância, com bordadura de $2 \mathrm{~m}$. Para cada local e época, foi realizada análise química de solo para cálculo de adubação mineral de plantio e de cobertura. Não foram utilizados inseticidas ou fungicidas e o controle de plantas invasoras foi feito por meio de capina manual na época de desbaste.

O delineamento experimental utilizado foi o de blocos ao acaso. Cada um dos 12 tratamentos (genótipos) teve 6 repetições, num total de 72 parcelas por experimento. As parcelas foram formadas por duas linhas de $5 \mathrm{~m}$, com espaçamento de 0,9 m entre linhas e 0,2 m entre plantas, num total de 50 plantas por parcela após o desbaste.

\subsubsection{Avaliação dos danos}

Os danos provocados pela lagarta-do-cartucho nos genótipos de milho foram avaliados em duas idades de plantas, utilizando-se uma escala visual de notas, adaptada de Williams et al. (1983) (Tabela 3) e ilustrada na Figura 2.

A primeira avaliação foi realizada entre a $3^{a}$ e a $4^{a}$ semana após a emergência, quando as plantas atingiram o estádio "V6-V8" (6 a 8 folhas abertas) e a segunda avaliação realizada entre a $6^{a}$ e a $7^{a}$ semana após a emergência, com plantas no estádio "V10-12" (10 a 12 folhas abertas).

As avaliações foram feitas por dois técnicos, cada um avaliando 20 plantas por parcela, não necessariamente as mesmas plantas, de tal modo que se obteve um total de 40 notas para compor a média de cada parcela. Os 
avaliadores foram sempre os mesmos e nos casos em que não foi possível a presença de um deles, considerou-se apenas a média das 20 notas de um avaliador.

Tabela 3. Escala para atribuição de notas de danos causados por $S$. frugiperda em plantas de milho (adaptada de Williams et al., 1983).

\begin{tabular}{cl}
\hline Notas & \multicolumn{1}{c}{ Descrição dos danos } \\
\hline 0 & Sem danos visíveis. \\
1 & Pequenas pontuações (tipo alfinete ou raspagem) em poucas folhas. \\
2 & Pequenos danos em forma de furos em poucas folhas. \\
3 & Danos em forma de furos em várias folhas. \\
4 & Danos em forma de furos em várias folhas e lesões em poucas folhas. \\
5 & Lesões em várias folhas. \\
6 & Grandes lesões em várias folhas. \\
7 & Grandes lesões em várias folhas e porções comidas em poucas folhas. \\
8 & Grandes lesões e grandes porções comidas em várias folhas. \\
9 & Grandes lesões e grandes porções comidas na maioria das folhas. \\
\hline
\end{tabular}

\subsubsection{Análise estatística}

Para determinar os danos causados pela lagarta-do-cartucho nos genótipos de milho, foram feitas as estatísticas descritivas para cada combinação de genótipo, local e época de cultivo, para cada uma das duas idades de plantas avaliadas.

Os danos foram comparados conjuntamente utilizando-se a análise de variância conjunta com medidas repetidas, uma vez que o mesmo lote de plantas de cada parcela, em cada experimento, foi avaliado em duas idades diferentes (estádios V6-V8 e V10-V12). 

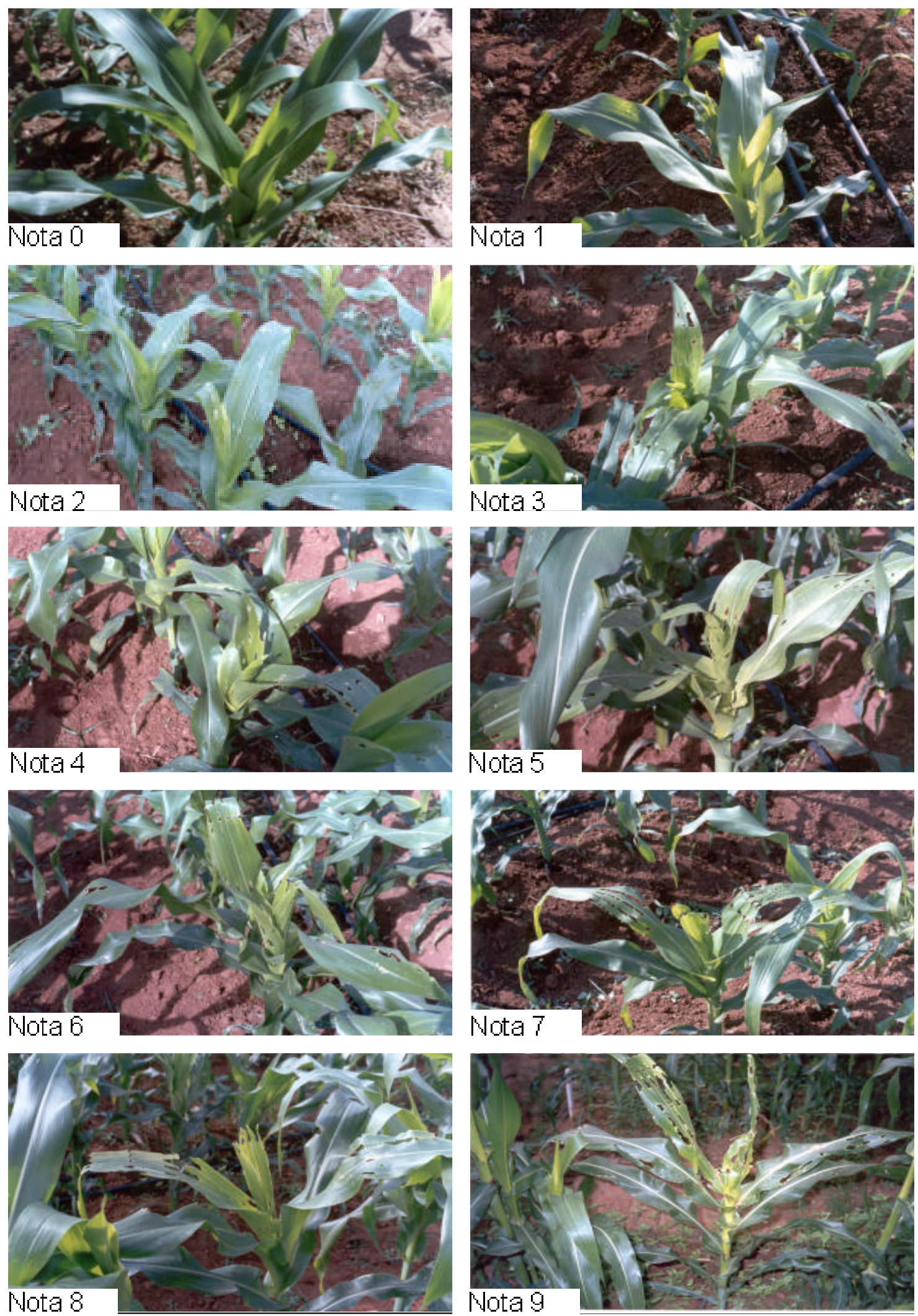

Figura 2 - Danos causados pela lagarta-do-cartucho, segundo escala visual de notas. 
Como a análise de variância conjunta com todos os fatores mostrou que os locais foram diferentes quanto à intensidade de danos e estes também foram diferentes nas duas idades avaliadas, dentro dos locais, optou-se por fazer uma análise de variância para cada local separadamente, considerando-se como fatores o "genótipo" com 12 níveis e a "época de cultivo" com quatro níveis (safra 99/00, safrinha 2000, safra 00/01 e safrinha 2001).

Devido à impossibilidade de conclusão dos experimentos da safrinha 2000 em Florínea e Miguelópolis e da safrinha 2001 em Guaíra (item 3.2.1), as análises de variância foram feitas com o número de níveis, para o fator época de cultivo, disponíveis em cada local.

A comparação das médias entre os locais e entre as épocas de cultivo, em cada local, foram feitas pelo teste de Tukey. A comparação múltipla de médias entre os genótipos foi feita utilizando-se o teste de Duncan. Para comparar as médias entre as idades V6-V8 e V10-V12, foi utilizado o teste de perfil de contraste ou teste t pareado, já que as notas foram tomadas no mesmo lote de plantas, em idades diferentes.

Em razão da variabilidade de valores e de observações discrepantes, sem suposição válida de normalidade (heterocedasticidade pelo teste de Bartlett), optou-se pela transformação dos dados (notas de dano) por ranks das notas (Montgomery, 1991), já que as transformações logarítimica e raiz quadrada não se mostraram adequadas.

O nível de significância adotado em todos os testes estatísticos foi de $5 \%$ $(p<0,05)$.

Para se averiguar uma possível formação de grupos de genótipos mais homogêneos entre si em relação ao dano da lagarta-do-cartucho, foi realizada a análise de agrupamento (Cluster Analysis), utilizando-se o método hierárquico para formação das seqüências de conglomerados e a função average linkage para determinação da distância entre os conglomerados (Kaufman \& Rousseeuw, 1990). As combinações usadas foram: local, época de cultivo e as duas idades da planta. 
Também foi calculada a distribuição de freqüência das notas atribuídas aos danos causados pela lagarta-do-cartucho para as idades de 6 a 8 e 10 a 12 folhas.

\subsection{Experimentos em condições de laboratório}

Os experimentos em condições de laboratório foram realizados no Centro Experimental Central do Instituto Biológico, na Fazenda Mato Dentro, Campinas - SP, junto ao Laboratório de Entomologia Econômica, durante o período de setembro de 2001 a março de 2002.

Inicialmente, avaliou-se por meio de diversos parâmetros biológicos o desenvolvimento da lagarta-do-cartucho quando alimentada com folhas dos genótipos testados. A seguir, avaliou-se a não-preferência para alimentação de lagartas de $S$. frugiperda, em quatro genótipos de milho, selecionados a partir dos resultados dos experimentos de campo e de laboratório.

Os experimentos foram realizados utilizando-se lagartas de $S$. frugiperda provenientes da criação do laboratório, mantidas em dieta artificial. As salas para manutenção da criação, bem como para realização dos experimentos, foram reguladas e mantidas na temperatura: $25 \pm 1^{\circ} \mathrm{C}$, umidade relativa: $70 \pm 10 \%$ e fotofase: 14 horas.

Os genótipos foram plantados em canteiros próximos ao laboratório, utilizando-se sementes obtidas da mesma forma como descrito no item 3.2.1. Foram realizadas a adubação de plantio e de cobertura, conforme a análise química do solo e não foi feito nenhum tipo de controle de pragas ou doenças. As pequenas infestações de $S$. frugiperda que ocorreram nos canteiros foram controladas manualmente, por esmagamento das lagartas. A irrigação dos canteiros foi realizada regularmente, padronizando-se a quantidade de água para todos os tratamentos.

Todos os experimentos foram iniciados quando as plantas atingiram o estádio V6-V8 ( 6 a 8 folhas abertas), período coincidente entre a $3^{a}$ e $4^{a}$ 
semana após a emergência. As folhas coletadas nos canteiros foram trazidas para o laboratório, onde foram lavadas em água corrente e depois mantidas em frascos com água, para manutenção da turgescência, até serem utilizadas.

\subsubsection{Desenvolvimento de S. frugiperda em genótipos de milho}

O desenvolvimento de $S$. frugiperda alimentada com folhas de milho de diferentes genótipos foi avaliado realizando-se cinco experimentos (blocos), cada um constando de 25 repetições (tubo com 1 lagarta) por tratamento e utilizando-se os seguintes parâmetros biológicos:

- Fase larval

- Peso aos 7 e 14 dias;

- Duração;

- Viabilidade.

- Fase pupal

- Peso após 24 horas (machos e fêmeas);

- Duração;

- Viabilidade;

- Porcentagem de deformação.

- Fase adulta

- Número de ovos/fêmea;

- Número de ovos/postura/fêmea;

- Longevidade (machos e fêmeas);

- Porcentagem de deformação.

Foram consideradas pupas deformadas aquelas que apresentaram alongamento dos urômeros, falhas na quitinização do $3^{\circ}$ e $4^{\circ}$ urômeros, retenção de caracteres morfológicos larvais, tumores visíveis e/ou "bolsa 
aquosa" na asa (Parra, 2000). Foram considerados deformados os adultos com asas defeituosas e com incapacidade de se desprender da pupa ( $\mathrm{Ng}$ et al., 1985).

Folhas de milho foram cortadas transversalmente às nervuras, em pedaços de $5 \mathrm{~cm}$ de comprimento que foram colocados em tubos de vidro de fundo chato de $8,5 \times 2,5 \mathrm{~cm}$, tampados com algodão hidrófugo e previamente esterilizados em estufa a $180^{\circ} \mathrm{C}$, por duas horas.

As lagartas recém-eclodidas permaneceram em dieta artificial por 24 horas e foram então transferidas para os tubos contendo as folhas de milho. As folhas foram trocadas diariamente em quantidade suficiente, até as lagartas atingirem a fase de pré-pupa. Nessa fase, os tubos não foram mais manipulados para que ocorresse a formação das pupas. As lagartas foram pesadas aos 7 e 14 dias de desenvolvimento. Aquelas que no $14^{\circ}$ dia de vida apresentavam-se em fase de pré-pupa ou próxima a ela, não foram pesadas ou o seu peso não foi considerado para efeito dos cálculos estatísticos.

Após 24 horas, as pupas formadas foram recolhidas, pesadas em balança analítica, separadas por sexo (Butt \& Cantu, 1962) e banhadas em solução de hipoclorito de sódio a $5 \%$, por dois minutos, seguido de banho de água destilada. Em seguida, foram colocadas em bandejas revestidas com papel de filtro umedecido com água destilada e individualizadas por meio de copinhos plásticos de $50 \mathrm{ml}$ até a emergência dos adultos. Essas bandejas foram umedecidas diariamente a fim de se manter um ambiente de umidade favorável ao desenvolvimento pupal. À medida que emergiram, os adultos nascidos na mesma data foram agrupados em casais, procurando-se formar no mínimo três e no máximo quatro casais por tratamento em cada bloco. Dessa forma, ao final do experimento, foram formados entre 15 e 20 casais para obtenção dos dados de fecundidade. Os adultos não utilizados na formação de casais permaneceram individualizados e alimentados com solução de mel a $10 \%$ até que completassem a fase adulta e fosse determinada a longevidade. Os adultos que formaram os casais foram igualmente alimentados com solução 
de mel a $10 \%$ e também considerados no cálculo da longevidade. Esses casais foram mantidos em gaiolas de PVC de $20 \mathrm{~cm}$ de altura e $10 \mathrm{~cm}$ de diâmetro, revestidas internamente com folhas de papel jornal, as quais serviram como substrato para as posturas. Estas foram recolhidas diariamente, identificadas e armazenadas em geladeira para posterior contagem dos ovos, evitando-se, assim, que ocorresse eclosão das lagartas. Os ovos foram contados na sua totalidade, sendo separados por meio de uma alça delgada de metal e num prazo não superior a 3 dias da data da postura.

Para maior consistência das análises estatísticas e evitar a influência de valores discrepantes, foi realizado o teste de igualdade de variâncias entre os tratamentos (homocedasticidade), utilizando-se o teste de Bartelett $(p<0,05$ indicando heterocedasticidade). A comparação dos parâmetros biológicos entre os genótipos foi feita utilizando-se a análise de variância simples e a comparação das médias feita pelo teste de Duncan. O nível de significância adotado em todos os testes estatísticos foi de $5 \%(p<0,05)$.

Para analisar possíveis grupos de genótipos formados em relação aos diversos parâmetros avaliados foi utilizada a análise de conglomerados (Cluster Analisys) com o método hierárquico para formação das seqüências dos grupos e a função average linkage para determinação das distâncias entre os conglomerados (Kaufmam \& Rousseeuw, 1990).

\subsubsection{Não-preferência para alimentação de lagartas de $S$. frugiperda em genótipos de milho}

O teste de não-preferência com chance de escolha para alimentação foi realizado utilizando-se 4 genótipos de milho (XL 212, IAC-21, C 333 B e Master) selecionados entre os 12 testados em condições de campo e laboratório.

Das folhas de cada genótipo foram cortados 2 pedaços sobrespostos de $2 \times 3 \mathrm{~cm}$. Foram utilizadas as partes laterais do terço basal das folhas, descartando-se a nervura central. Os pedaços de folhas foram então fixados 
aleatória e circularmente em arenas. Cada arena foi formada por uma placa de Petri de $15 \mathrm{~cm}$ de diâmetro, com uma fina camada de gesso no fundo revestida de papel de filtro umedecido com água destilada. Para o centro de cada arena foram então transferidas 50 lagartas de $S$. frugiperda recém-eclodidas; em seguida, as arenas foram fechadas e vedadas com fita crepe.

Cada arena foi considerada um bloco completo, sendo montados 20 blocos no total.

A avaliação foi feita após 24 horas, anotando-se o número total de lagartas presentes nos genótipos e o número de lagartas presentes em cada genótipo. Foram considerados válidos para efeito de análise estatística apenas os blocos onde o número de lagartas presentes nos genótipos tenha sido superior a $70 \%$ das lagartas liberadas.

Para comparar a não-preferência entre os 4 genótipos, foi utilizada a análise de variância simples e a comparação das médias feita pelo teste de Duncan. Para normalização da distribuição dos valores, foi utilizada a transformação dos dados em arco-seno da raiz quadrada. O nível de significância adotado foi de $5 \%(p<0,05)$. 


\section{RESULTADOS E DISCUSSÃO}

\subsection{Experimentos em condições de campo}

A falta de dados referentes aos locais onde não puderam ser concluídos os experimentos de campo (safrinha de 2000, em Florínea e Miguelópolis e safrinha de 2001, em Guaíra) impossibilitou determinadas combinações de fatores para a análise de variância conjunta (genótipo, local, época de cultivo e idade da planta). Assim, foi feita uma análise de variância com as combinações possíveis para cada local separadamente, mostrando inicialmente que esses locais foram distintos em relação aos danos provocados pelas lagartas de Spodoptera frugiperda (J.E. Smith, 1797), nos genótipos de milho.

\subsubsection{Análise de variância conjunta entre locais e entre idades, dentro dos locais}

$\mathrm{Na}$ análise de variância conjunta entre os locais (Tabela 4), os resultados foram significativos para local $(p=0,0409)$, indicando que pelo menos um dos locais avaliados foi diferente dos demais em relação aos danos da lagarta-docartucho. $O$ fator genótipo também foi significativo $(p=0,0266)$, mostrando que houve diferenças nos danos ocorridos entre os materiais testados, porém esse fator não foi determinante para a diferença entre os locais, uma vez que a interação genótipo*ambiente não foi significativa. 
Tabela 4. Quadrados médios e significância na análise de variância conjunta entre locais para danos de $S$. frugiperda, em genótipos de milho.

\begin{tabular}{lrccc}
\hline Fonte de Variação & GL & Quadrados Médios & Valor de $F$ & PR $>$ F \\
\hline Genótipo & 11 & 3364,71 & 2,00 & $0,0266{ }^{*}$ \\
Local & 2 & 5415,31 & 3,21 & $0,0409{ }^{*}$ \\
Genótipo x Local & 22 & 708,75 & 0,42 & 0,9914 ns \\
Resíduo & 612 & 1685,79 & & \\
\hline * = significativo pelo teste $\mathrm{F}: \mathrm{p}<0,05$ & & & \\
ns $=$ não significativo
\end{tabular}

$\mathrm{Na}$ análise de variância para o fator idade dentro dos locais, a interação idade*local foi significativa $(p=0,0001)$ indicando que dependendo do local analisado os danos foram diferenciados em cada idade (Tabela 5).

Tabela 5. Quadrados médios e significância na análise de variância conjunta dentro dos locais para danos de $S$. frugiperda em genótipos de milho, avaliados em duas idades da planta.

\begin{tabular}{lrcrc}
\hline Fonte de Variação & $\mathrm{GL}$ & Quadrados Médios & Valor de $\mathrm{F}$ & $\mathrm{PR}>\mathrm{F}$ \\
\hline Idade & 1 & 158530,04 & 275,39 & $0,0001^{* *}$ \\
Idade x Genótipo & 11 & 394,66 & 0,69 & $0,7529^{\mathrm{ns}}$ \\
Idade x Local & 2 & 138693,88 & 240,93 & $0,0001^{* *}$ \\
Idade x Local x Genótipo & 22 & 472,82 & 0,82 & $0,7002{ }^{\mathrm{ns}}$ \\
Resíduo & 612 & 575,65 & & \\
\hline
\end{tabular}

${ }^{* *}=$ significativo pelo teste $\mathrm{F}: \mathrm{p}<0,01$

${ }^{\text {ns }}=$ não significativo

Uma vez que houve significância na análise de variância para os fatores local e idade*local, as médias dos genótipos foram comparadas entre os locais e entre as idades, dentro de cada local (Tabela 6). Houve diferenças de danos nas duas idades de planta estudadas. Na idade de 6 a 8 folhas, os danos foram significativamente menores em Casa Branca $(2,95)$ em relação à Florínea $(3,77)$ e Miguelópolis/Guaíra (3,76), que não diferiram entre si. Já, na idade de 10 a 12 folhas, os danos foram significativamente distintos nos três locais. Em Miguelópolis/Guaíra ocorreram os menores danos $(2,41)$, seguindo-se Florínea 
$(2,85)$ e Casa Branca $(3,67)$, que também diferiram entre si. Os resultados das comparações das médias entre as idades para cada local (Tabela 6) evidenciaram que em Casa Branca, os genótipos foram mais danificados no estádio de 10 a 12 folhas. Já, em Florínea e Miguelópolis/Guaíra isso ocorreu no estádio de 6 a 8 folhas.

Tabela 6. Médias gerais entre locais e entre as idades dentro de cada local, para danos causados por S. frugiperda em genótipos de milho.

\begin{tabular}{lcc}
\hline \multicolumn{1}{c}{ Local } & Idade 6-8 folhas & Idade 10-12 folhas \\
\hline Casa Branca & $2,95 \pm 0,24$ a A & $3,67 \pm 0,30$ c B \\
Florínea & $3,77 \pm 0,23$ b B & $2,85 \pm 0,17$ b A \\
Miguelópolis / Guaíra & $3,76 \pm 0,19$ b B & $2,41 \pm 0,15$ a A \\
C. V. (\%) & 46,59 & 58,52 \\
\hline
\end{tabular}

Médias ( \pm EP) seguidas de letras distintas minúsculas nas colunas diferem estatisticamente entre si pelo teste de Tukey $(p<0,05)$.

Médias ( $\pm \mathrm{EP})$ seguidas de letras distintas maiúsculas nas linha diferem estatisticamente entre si pelo teste t pareado $(p<0,05)$.

No geral, as médias verificadas nos três locais podem ser consideradas baixas (Casa Branca $=3,31$; Florínea $=3,31$; Miguelópolis $/$ Guaíra $=3,08$ ), dentro da escala de 0 a 9, porém, em se tratando de experimentação de campo em diferentes locais e épocas e sob infestação natural, isso pode ocorrer já que muitos fatores bióticos e abióticos nem sempre podem ser controlados durante a experimentação. Numa outra análise, considerando-se a distribuição de freqüência das notas de dano nos locais, épocas de cultivo e genótipos, conjuntamente, verifica-se que os maiores percentuais de freqüência foram para as notas 2 e 3 , nas duas idades analisadas. Comparando-se as freqüências das notas de dano causadas pela lagarta-do-cartucho, nas folhas de milho, nas idades de 6 a 8 folhas e de 10 a 12 folhas (Figura 3), verifica-se que a nota 3 apresentou freqüência de $27 \%$ na idade de 6 a 8 folhas e $27,7 \%$ na idade de 10 a 12 folhas. A nota 2 apresentou freqüência maior na idade de 10 a 12 folhas $(28,8 \%)$ em relação à idade de 6 a 8 folhas $(21,5 \%)$. Na faixa 
entre $10 \%$ e $20 \%$ ficaram: a nota $4(17,4 \%)$ e a nota $5(13,7 \%)$ na idade de 6 a 8 folhas e a nota $1(13,1 \%)$ e a nota $4(11,1 \%)$ na idade de 10 a 12 folhas. As notas 7, 8 e 9, que representam danos mais significativos, apresentaram baixos percentuais de freqüência (menor que $5 \%$ ) nas duas idades avaliadas. Já, a nota zero representou freqüência de $1,6 \%$ e 1,8\% nas idades de 6 a 8 folhas e de 10 a 12 folhas respectivamente.

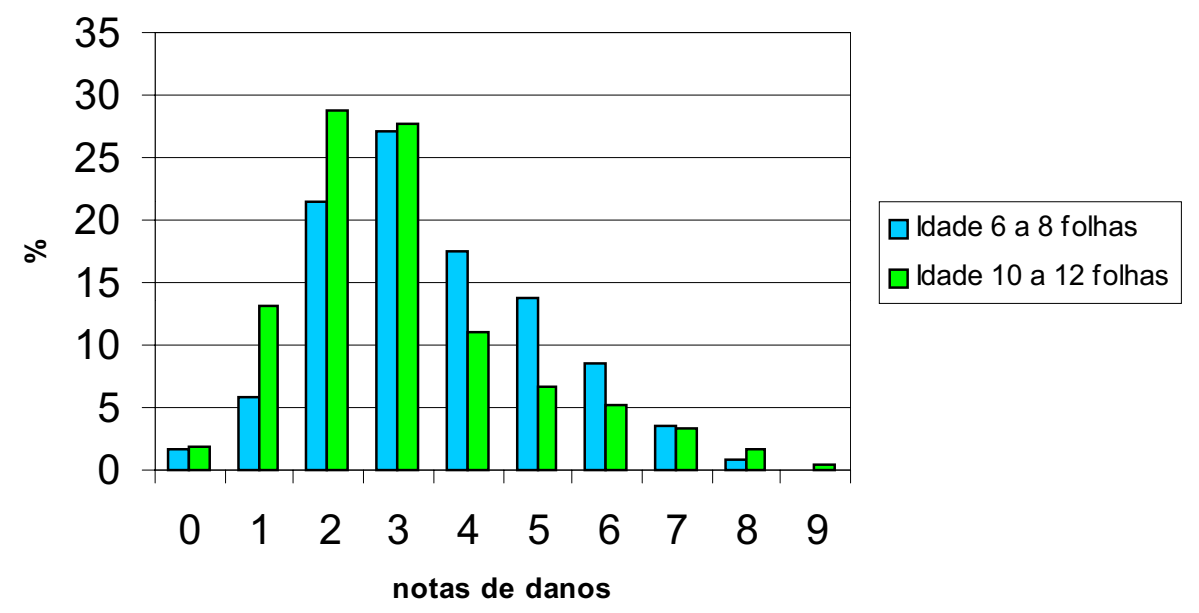

Figura 3 - Distribuição de freqüência das notas de danos causados por $S$. frugiperda em folhas de milho, em duas idades de plantas.

Todos os experimentos foram montados em propriedades de agricultores e em áreas onde estavam sendo cultivados o milho (safras) ou milho e outras gramíneas como sorgo e triticale (safrinhas), à exceção de Miguelópolis, na safra 1999/2000, onde, à época do plantio experimental, a área estava plantada com milho silagem, o qual foi colhido no período da primeira avaliação. Os plantios experimentais foram realizados sempre após o plantio dos agricultores, esperando-se justamente maior infestação nessas áreas e a migração da população da praga para as áreas experimentais. Embora nos plantios dos agricultores tenha sido realizado controle químico, as bordaduras (4 linhas) não foram pulverizadas e as parcelas experimentais foram instaladas à distância de pelo menos $4 \mathrm{~m}$ dessas bordaduras. Mesmo não sendo considerada a hipótese 
de deriva direta na área experimental, pode ter ocorrido diminuição da população da praga pelo uso de inseticidas nas áreas adjacentes. Entretanto, esses locais foram escolhidos por serem municípios de expressão na produção de milho e por apresentarem forte pressão de seleção da lagarta-do-cartucho.

Williams et al. (1978) avaliaram por dois anos a resistência de genótipos de milho, sob infestação natural. No segundo ano, quatro semanas após o plantio, as lagartas já haviam danificado os genótipos suscetíveis e encaminhavam-se para os genótipos resistentes, causando nos mesmos uma rápida destruição, o que levou os autores a antecipar a avaliação, modificando inclusive a escala de notas. Lara et al. (1984), avaliando diversos genótipos de milho, realizaram três avaliações e encontraram pouca variação nas notas (de 1,01 a 2,31, numa escala de 0 a 5 ) e baixas porcentagens de plantas com danos elevados (notas 4 e 5). Fato semelhante foi verificado por Tozetti et al. (1995), quando obtiveram em condições de safrinha e sob infestação natural, dano médio de 1,79 (escala de 0 a 5). Os autores atribuíram esse baixo valor médio ao ambiente e ao nível da população da praga, considerando que esses fatores têm bastante influência na seleção de materiais resistentes a insetos, em condições de campo. Entretanto, a diferenciação entre genótipos resistentes e suscetíveis pode ser feita mesmo que o intervalo de variação entre a menor e a maior nota não seja tão grande, desde que haja homogeneidade no campo experimental. Scott et al. (1982) registraram as linhagens Mp701 e Mp702, resistentes a $D$. grandiosella e também a $S$. frugiperda, fazendo seleção por meio de infestação artificial com massas de ovos. Utilizando uma escala de 0 a 9, obtiveram as médias 5,7 para Mp701 e 5,8 para Mp702, contra 6,2 para Mp496 (reconhecidamente uma linhagem resistente) e 7,8 para a linhagem suscetível.

Scriber \& Slansky Jr. (1981) destacaram a importância da qualidade do alimento influenciando a performance de crescimento de insetos, e destacaram ainda que fatores bióticos e abióticos também afetam essa performance, como, por exemplo, a escolha e utilização do alimento. 
Dentre os efeitos abióticos, a disponibilidade de nutrientes no solo é também considerada. O nitrogênio pode ter efeito favorável (Chang et al., 1985) ou desfavorável (Leuck, 1972) ao desenvolvimento de S. frugiperda. Leuck (1972) considerou que embora esses efeitos fossem pouco prováveis no campo, fatores como tipo de solo, lixiviação de nutrientes, fertilidade residual e tempo de aplicação de fertilizantes poderiam promover vários efeitos na relação inseto-planta. Nos três locais onde foram montados os experimentos, a correção do solo com fertilizantes foi feita com base na análise química do solo, realizada em todas as épocas, não havendo, entretanto, nenhuma recomendação que fugisse à média de adubação realizada pelos agricultores. Nos ensaios experimentais, foi sempre realizada adubação de cobertura, efetuada após a primeira avaliação. Entretanto, o fator fertilidade parece não ter tido um efeito direto no nível de infestação.

Outro aspecto a ser considerado em relação às baixas médias gerais, constatadas nos experimentos de campo, está relacionado à pseudo-resistência do tipo evasão hospedeira ou assincronia fenológica; as plantas podem apresentar o período de maior suscetibilidade no momento de menor densidade populacional da praga. Dentre os genótipos testados no presente trabalho, encontram-se materiais dos tipos: normal, precoce e superprecoce, ocorrendo, portanto, variação no desenvolvimento das plantas dentro de cada experimento. Desse modo, foram realizadas duas avaliações, uma no estádio de 6 a 8 folhas e outra no estádio de 10 a 12 folhas, procurando-se não apenas uma possível identificação da fase mais suscetível dos genótipos, mas principalmente minimizar o efeito da assincronia fenológica na avaliação desses genótipos, considerando-se que foram avaliados em diferentes locais e em épocas com diferentes condições edafoclimáticas (Tabela 2). A literatura tem mostrado que o estádio de desenvolvimento da planta de milho mais suscetível aos danos da lagarta-do-cartucho é mais bem identificado em experimentos com infestações artificiais. De modo geral, tem sido verificado que plantas de milho são sensíveis aos ataques de $S$. frugiperda em praticamente todas as fases de 
desenvolvimento (Cruz, 1995; Williams \& Buckley, 1992). Entretanto, os estádios iniciais (de seedling até V-4) (Cruz \& Turpin, 1982; Wiseman et al., 1996) e os estádios finais de desenvolvimento vegetativo (de V-14 até préfloração) (Videla et al., 1992) parecem ser menos importantes que os estádios de "cartucho primário" (V-6), "cartucho intermediário" (V-8) e "cartucho adiantado" (V-10) nos quais têm sido observada maior suscetibilidade e são melhor estudados os mecanismos e as bases da resistência (Davis et al., 1998; Williams \& Buckely, 1992; Williams et al., 1990; Williams et al., 1990; Wiseman et al., 1996; Yang et al., 1991).

No presente trabalho, foi verificado que a diferença de danos apresentada entre as idades de 6 a 8 folhas e 10 a 12 folhas, conforme o local avaliado, deuse principalmente durante a fase de desenvolvimento da planta em que ocorreu o pico de infestação (significância na interação idade*local), não sendo os genótipos determinantes na diferença (interações idade*genótipo e idade*genótipo*local não significativas). Isso pode ser observado adiante, nas comparações lineares dos genótipos com diferentes idades, em cada época e local. Verificou-se comportamento bastante homogêneo dos genótipos em relação aos danos, não tendo sido encontrados genótipo(s) mais danificado(s) no estádio V6-V8 e outro(s) mais danificado(s) em V10-V12, dentro de uma mesma época e local. Por outro lado, o fator genótipo foi significativo na análise de variância conjunta; mesmo tendo sido considerado baixo o nível de infestação, foi possível distinguir entre os genótipos testados aqueles menos danificados em relação aos que sofreram maiores danos.

\subsubsection{Resultados da análise de variância conjunta em Casa Branca - SP}

Os resultados da análise de variância entre as épocas de cultivo (Tabela 7) evidenciam que houve significância para o fator época $(p=0,001)$, indicando que em pelo menos uma das épocas avaliadas os danos foram diferentes. A interação genótipo*época não foi significativa, ou seja, a diferença entre as 
épocas de cultivo não foi determinada pelos genótipos. Pelos resultados da análise de variância para o fator idade, dentro das épocas de cultivo (Tabela 8), verifica-se que a interação idade*época foi significativa $(p=0,0001)$, indicando que os danos foram distintos em cada idade, dependendo da época analisada. As médias gerais dos genótipos comparadas entre si nas épocas, em cada idade, e entre as idades, em cada época (Tabela 9) mostra que na idade de 6 a 8 folhas os danos foram significativamente distintos entre as duas safrinhas e entre estas e as safras, as quais, por sua vez, não apresentaram diferença significativa entre si. Na safrinha de 2000 , a média dos danos $(1,29)$ foi menor em relação à safrinha de $2001(3,28)$, sendo esta ainda significativamente menor que as médias das safras de 2000/2001 (3,60) e 1999/2000 (3,62). Na idade de 10 a 12 folhas, as médias dos danos foram significativamente diferentes em todas as épocas, obedecendo-se, entretanto, a mesma ordem, de menor para maior dano, observada em V6-V8, ou seja, safrinha $2000(2,02)$, safrinha $2001(3,31)$, safra 2000/2001 (3,61) e safra 1999/2000 (5,75).

Tabela 7. Quadrados médios e significância na análise de variância conjunta entre épocas de cultivo, para danos causados por $S$. frugiperda em genótipos de milho, em Casa Branca - SP.

\begin{tabular}{lrcrr}
\hline Fonte de Variação & GL & Quadrado Médio & Valor de F & PR > F \\
\hline Genótipo & 11 & 1263,36 & 2,87 & $0,0015^{* *}$ \\
Época & 3 & 202091,85 & 458,73 & $0,0001^{* *}$ \\
Genótipo x Época & 33 & 370,16 & 0,84 & $0,7191^{\text {ns }}$ \\
Resíduo & 240 & 440,55 & & \\
\hline $\begin{array}{l}\text { ** }=\text { significativo pelo teste F: } p<0,01 \\
\text { ns }\end{array}=$ não significativo & & & & \\
\end{tabular}


Tabela 8. Quadrados médios e significância na análise de variância conjunta dentro das épocas de cultivo, para danos causados por S. frugiperda em genótipos de milho, avaliados em duas idades, em Casa Branca $-\mathrm{SP}$.

\begin{tabular}{lrcrc}
\hline \multicolumn{1}{c}{ Fonte de Variação } & GL & Quadrado Médio & Valor de F & PR > F \\
\hline Idade & 1 & 38059,94 & 116,96 & $0,0001{ }^{* *}$ \\
Idade x Genótipo & 11 & 408,13 & 1,25 & $0,2522^{\mathrm{ns}}$ \\
Idade x Época & 3 & 14652,37 & 45,03 & $0,0001^{* *}$ \\
Idade x Genótipo x Época & 33 & 445,74 & 1,37 & $0,0952^{\mathrm{ns}}$ \\
Resíduo & 240 & 325,42 & & \\
\hline
\end{tabular}

** = significativo pelo teste $\mathrm{F}: \mathrm{p}<0,01$

ns $=$ não significativo

Tabela 9. Médias gerais entre as épocas, e entre as idades em cada época, para danos causados por $S$. frugiperda em genótipos de milho, em Casa Branca - SP.

\begin{tabular}{lcc}
\hline \multicolumn{1}{c}{ Época de Cultivo } & Idade 6-8 folhas & Idade 10-12 folhas \\
\hline Safra 99/00 & $3,62 \pm 0,30$ c A & $5,75 \pm 0,30$ d B \\
Safrinha 2000 & $1,29 \pm 0,12$ a A & $2,02 \pm 0,17$ a B \\
Safra 00/01 & $3,60 \pm 0,31$ c A & $3,61 \pm 0,23$ c A \\
Safrinha 2001 & $3,28 \pm 0,16$ b A & $3,31 \pm 0,17$ b A \\
C.V. (\%) & 37,95 & 22,79 \\
\hline
\end{tabular}

Médias $( \pm$ EP) seguidas de letras distintas minúsculas nas colunas diferem estatisticamente entre si pelo teste de Tukey $(p<0,05)$.

Médias ( $\pm \mathrm{EP})$ seguidas de letras distintas maiúsculas nas linha diferem estatisticamente entre si pelo teste t pareado $(p<0,05)$.

O município de Casa Branca possui grande expressão de cultivo de milho em safra e menor expressão em safrinha, com cultivo de outras culturas como girassol, triticale e sorgo. Entretanto, durante os dois anos em que foram realizados os ensaios, foram cultivados sorgo na safrinha de 2000 e triticale na safrinha de 2001, gramíneas hospedeiras da lagarta-do-cartucho.

Ainda com relação à safrinha de 2000 , as avaliações foram realizadas bem no início de cada estádio, tanto em V6-V8 (28 DAP) quanto em V10-V12 (42 DAP), sendo possível que a população da praga não estivesse totalmente 
estabelecida na cultura, principalmente em V6-V8. Considerando-se um período de 8 dias, em média, para a germinação do milho na safrinha, aos 28 dias após o plantio, as plantas estariam bem no início da fase de 6 a 8 folhas. A cultura do sorgo, plantado nas adjacências, estava na fase de 8 folhas abertas. Isso pode ter influenciado a migração da praga para a área experimental.

Nos danos entre as duas idades, em cada época, houve diferença significativa entre as médias na safra 1999/2000 (3,62 em V6-V8 e 5,75 em V10-V12) e na safrinha 2000 (1,29 em V6-V8 e 2,02 em V10-V12). Assim, essas duas épocas de cultivo no ano agrícola de 1999/2000 (safra e safrinha) foram as que determinaram os maiores danos na idade de 10 a 12 folhas em relação a V6-V8, em Casa Branca (Tabela 6). A partir desses dados, destacase a importância da combinação de fatores na avaliação do comportamento de genótipos visando resistência a insetos, os quais permitiram melhor interpretação dos resultados obtidos e a possibilidade de serem identificadas fontes de resistência. Williams et al. (1983) estudaram as correlações entre genótipos resistentes e suscetíveis com dois estádios de desenvolvimento da planta (V5 e V10), e o efeito destes (genótipo e estádios de desenvolvimento) na fase larval da lagarta-do-cartucho. Os experimentos foram conduzidos em dois anos consecutivos e em dois locais. Os autores analisaram conjuntamente os dados dos fatores e ressaltaram que a combinação deles proporcionou uma indicação mais clara do nível de resistência dos vários genótipos.

No presente trabalho, com a análise de variância, constatou-se que houve significância para o fator genótipo e também para a interação idade*época. Assim, foi realizada a comparação das médias entre os genótipos em cada idade e entre as idades em cada genótipo, para cada uma das épocas avaliadas em Casa Branca.

Os resultados da comparação das médias para a safra 1999/2000 (Tabela 10) evidenciaram que, na idade de 6 a 8 folhas, os genótipos Dina $766(3,12), Z$ $8486(3,13)$ e C 333 B $(3,18)$ foram os que apresentaram as menores médias diferindo da obtida no genótipo Piranão $(4,36)$. Na idade de 10 a 12 folhas, os 
genótipos com menores danos foram Z $8486(5,19)$ e Dina $766(5,20)$, diferindo de XL $212(6,77)$, que apresentou o maior dano e de Piranão $(6,26)$, IACPariquera $(6,09)$, IAC-Vitória $(5,83)$ e Master $(5,79)$, que apresentaram dano intermediário. Na comparação dos genótipos nas duas idades avaliadas, a diferença estatística foi significativa para todos os tratamentos, com menor dano em V6-V8.

Tabela 10. Danos causados por lagartas de $S$. frugiperda sob infestação natural, em genótipos de milho, em duas idades, na safra de 1999/2000. Casa Branca - SP.

\begin{tabular}{|c|c|c|c|c|c|c|c|c|}
\hline \multirow[t]{2}{*}{ Genótipos } & \multicolumn{4}{|c|}{$6-8$ folhas } & \multicolumn{4}{|c|}{ 10-12 folhas } \\
\hline & \multicolumn{3}{|l|}{ Média ( \pm EP) } & \multirow{2}{*}{$\frac{\text { I.V. }}{2,80-3,65}$} & \multicolumn{3}{|l|}{ Média $( \pm E P)$} & \multirow{2}{*}{$\frac{\text { I.V. }}{4,00-6,40}$} \\
\hline Dina 766 & $3,12 \pm 0,12$ & $a$ & A & & $5,20 \pm 0,42$ & $a$ & $B$ & \\
\hline Z 8486 & $3,13 \pm 0,34$ & a & $A$ & $2,30-4,55$ & $5,19 \pm 0,26$ & a & B & $4,20-6,05$ \\
\hline C 333 B & $3,18 \pm 0,28$ & a & A & $2,05-3,95$ & $5,50 \pm 0,29$ & $a b c$ & B & $4,60-6,35$ \\
\hline IAC-21 & $3,39 \pm 0,14$ & $a b$ & $A$ & $3,05-3,85$ & $5,45 \pm 0,26$ & $a b c$ & B & $4,65-6,30$ \\
\hline Exceler & $3,40 \pm 0,28$ & $a b$ & $A$ & $2,85-4,75$ & $5,73 \pm 0,30$ & $a b c$ & B & $4,75-6,60$ \\
\hline Master & $3,44 \pm 0,31$ & $a b$ & A & $2,25-4,35$ & $5,79 \pm 0,27$ & bc & B & $5,05-6,65$ \\
\hline AG 1051 & $3,56 \pm 0,24$ & $a b$ & $A$ & $2,95-4,50$ & $5,55 \pm 0,22$ & $a b c$ & B & $4,75-6,00$ \\
\hline IAC-Pariquera & $3,83 \pm 0,40$ & $a b$ & A & $2,70-5,00$ & $6,09 \pm 0,32$ & bc & B & $4,65-6,80$ \\
\hline IAC-Vitória & $3,90 \pm 0,23$ & $a b$ & $A$ & $3,30-4,70$ & $5,83 \pm 0,25$ & $b c$ & B & $5,25-6,80$ \\
\hline CATI AL 30 & $4,03 \pm 0,34$ & $a b$ & A & $2,75-5,10$ & $5,69 \pm 0,26$ & $a b c$ & B & $4,95-6,70$ \\
\hline XL 212 & $4,05 \pm 0,59$ & $a b$ & A & $2,45-5,85$ & $6,77 \pm 0,43$ & C & B & $5,50-8,60$ \\
\hline Piranão VF1 & $4,36 \pm 0,31$ & $b$ & $A$ & $3,25-5,00$ & $6,26 \pm 0,29$ & bc & B & $5,45-7,40$ \\
\hline C.V. (\%) & & & 5,5 & & & 4 & & \\
\hline
\end{tabular}

Médias ( \pm EP) seguidas de mesma letra minúscula nas colunas não diferem estatisticamente entre si pelo teste de Duncan $(p<0,05)$.

Médias $( \pm E P)$ seguidas de mesma letra maiúscula nas linhas não diferem estatisticamente entre si pelo teste t pareado $(p<0,05)$.

Na safrinha de 2000 (Tabela 11), para a idade de 6 a 8 folhas as médias foram significativamente menores para os genótipos Master $(1,00)$, Z 8486 $(1,00)$, Exceler $(1,03)$ e Dina $766(1,07)$, em relação aos genótipos IACPariquera $(1,55)$ e XL $212(1,54)$, que apresentaram as maiores médias. Para a idade de 10 a 12 folhas, a menor média foi obtida no genótipo Exceler $(1,46)$ diferindo dos genótipos IAC-Pariquera $(2,62)$ e IAC-21 $(2,54)$ que apresentaram 
maior dano e de AG 1051 (2,26) e Piranão $(2,25)$ que apresentaram danos intermediários. Na comparação entre as idades, com exceção do genótipo Exceler, que não apresentou diferença nas médias entre as duas idades, todos os demais tratamentos diferiram estatisticamente entre si, com menores danos no estádio V6-V8.

Tabela 11. Danos causados por lagartas de $S$. frugiperda sob infestação natural, em genótipos de milho, em duas idades, na safrinha de 2000. Casa Branca - SP.

\begin{tabular}{llllccccc}
\hline Genótipos & \multicolumn{3}{c}{ 6-8 folhas } & \multicolumn{5}{c}{$10-12$ folhas } \\
& Média $( \pm$ EP) & & I.V. & Média $( \pm$ EP) & I.V. \\
\hline Master & $1,00 \pm 0,15$ & a & A & $0,65-1,65$ & $1,66 \pm 0,16$ & ab & B & $1,10-2,15$ \\
Z 8486 & $1,00 \pm 0,18$ & a & A & $0,58-1,75$ & $1,70 \pm 0,23$ & abc & B & $0,88-2,58$ \\
Exceler & $1,03 \pm 0,07$ & a & A & $0,75-1,20$ & $1,46 \pm 0,15$ & a & A & $0,90-2,03$ \\
Dina 766 & $1,07 \pm 0,04$ & a & A & $0,98-1,25$ & $1,70 \pm 0,17$ & abc & B & $1,18-2,23$ \\
C 333 B & $1,18 \pm 0,07$ & ab & A & $0,90-1,43$ & $1,75 \pm 0,09$ & abc & B & $1,58-2,13$ \\
Piranão VF1 & $1,33 \pm 0,20$ & abc & A & $0,75-2,10$ & $2,25 \pm 0,28$ & bcd & B & $1,43-3,18$ \\
IAC-Vitória & $1,38 \pm 0,16$ & abc & A & $0,78-1,78$ & $2,06 \pm 0,08$ & abc & B & $1,78-2,23$ \\
IAC-21 & $1,45 \pm 0,11$ & abc & A & $1,18-1,88$ & $2,54 \pm 0,21$ & d & B & $1,88-3,33$ \\
CATI AL 30 & $1,49 \pm 0,08$ & abc & A & $1,25-1,70$ & $2,06 \pm 0,16$ & abc & B & $1,65-2,50$ \\
AG 1051 & $1,49 \pm 0,12$ & abc & A & $0,93-1,73$ & $2,26 \pm 0,15$ & bcd & B & $1,65-2,75$ \\
XL 212 & $1,54 \pm 0,11$ & C & A & $1,25-1,95$ & $2,12 \pm 0,19$ & abcd & B & $1,55-2,93$ \\
IAC-Pariquera & $1,55 \pm 0,16$ & C & A & $1,08-2,03$ & $2,62 \pm 0,13$ & d & B & $2,28-3,05$ \\
C.V. (\%) & & 77,4 & & & 59,8 & \\
\hline
\end{tabular}

Médias ( $\pm \mathrm{EP})$ seguidas de mesma letra minúscula nas colunas não diferem estatisticamente entre si pelo teste de Duncan $(p<0,05)$.

Médias $( \pm E P)$ seguidas de mesma letra maiúscula nas linhas não diferem estatisticamente entre si pelo teste t pareado $(p<0,05)$.

$\mathrm{Na}$ safra 2000/2001 (Tabela 12), os genótipos não apresentaram diferenças significativas em nenhuma das idades avaliadas, sendo que as médias variaram entre 3,18 (Dina 766) e 4,33 (Exceler), na idade de 6 a 8 folhas, e de 3,30 (C 333 B) a 4,02 (XL 212), na idade de 10 a 12 folhas. Também não houve diferença significativa entre as duas idades avaliadas dos genótipos. 
Tabela 12. Danos causados por lagartas de $S$. frugiperda sob infestação natural, em genótipos de milho, em duas idades, na safra de 2000/2001. Casa Branca - SP.

\begin{tabular}{llllccccc}
\hline Genótipos & \multicolumn{3}{c}{ 6-8 folhas } & \multicolumn{5}{c}{$10-12$ folhas } \\
& Média $( \pm \mathrm{EP})$ & \multicolumn{1}{c}{ I.V. } & Média $( \pm \mathrm{EP})$ & I.V. \\
\hline Dina 766 & $3,18 \pm 0,41$ & a & $\mathrm{A}$ & $2,40-5,10$ & $3,45 \pm 0,16$ & a & A & $2,98-4,05$ \\
AG 1051 & $3,19 \pm 0,36$ & a & $\mathrm{A}$ & $2,55-4,75$ & $3,70 \pm 0,27$ & a & A & $2,78-4,48$ \\
C 333 B & $3,38 \pm 0,19$ & a & A & $2,80-4,15$ & $3,30 \pm 0,18$ & a & A & $2,83-3,88$ \\
Z 8486 & $3,43 \pm 0,17$ & a & A & $2,90-4,00$ & $3,65 \pm 0,26$ & a & A & $2,68-4,65$ \\
XL 212 & $3,45 \pm 0,27$ & a & A & $2,45-4,30$ & $4,02 \pm 0,36$ & a & A & $2,93-5,25$ \\
IAC-Pariquera & $3,57 \pm 0,13$ & a & A & $3,10-4,00$ & $3,49 \pm 0,20$ & a & A & $3,00-4,23$ \\
CATI AL 30 & $3,63 \pm 0,29$ & a & A & $2,90-4,90$ & $3,85 \pm 0,20$ & a & A & $3,10-4,58$ \\
Piranão VF1 & $3,71 \pm 0,29$ & a & A & $2,95-4,80$ & $3,41 \pm 0,14$ & a & A & $2,83-3,70$ \\
Master & $3,73 \pm 0,28$ & a & A & $2,90-4,55$ & $3,45 \pm 0,24$ & a & A & $3,00-4,60$ \\
IAC-Vitória & $3,78 \pm 0,62$ & a & A & $2,15-5,60$ & $3,60 \pm 0,32$ & a & A & $2,73-4,53$ \\
IAC-21 & $3,87 \pm 0,21$ & a & A & $3,05-4,45$ & $3,48 \pm 0,25$ & a & A & $2,58-4,40$ \\
Exceler & $4,33 \pm 0,53$ & a & A & $3,05-6,10$ & $3,88 \pm 0,17$ & a & A & $3,28-4,45$ \\
C.V. (\%) & & & 35,9 & & & 28,7 & \\
\hline
\end{tabular}

Médias ( $\pm E P$ ) seguidas de mesma letra minúscula nas colunas não diferem estatisticamente entre si pelo teste de Duncan $(p<0,05)$.

Médias $( \pm E P)$ seguidas de mesma letra maiúscula nas linhas não diferem estatisticamente entre si pelo teste t pareado $(p<0,05)$.

$\mathrm{Na}$ safrinha 2001, foram observadas diferenças significativas entre os genótipos, nas duas idades (Tabela 13). Na idade de 6 a 8 folhas, a menor média foi observada no genótipo Dina $766(2,97)$ diferindo dos genótipos Exceler $(3,63)$, Master $(3,58)$ e XL $212(3,48)$. Na idade de 10 a 12 folhas, o genótipo Master foi o que apresentou menor média $(2,91)$ diferindo dos genótipos XL 212 (3,60), IAC-21 (3,58) e CATI AL 30 (3,58). Na comparação entre genótipos com as idades, os resultados não apresentaram diferenças significativas. 
Tabela 13. Danos causados por lagartas de $S$. frugiperda sob infestação natural, em genótipos de milho, em duas idades, na safrinha de 2001. Casa Branca - SP.

\begin{tabular}{|c|c|c|c|c|c|c|c|}
\hline \multirow[t]{2}{*}{ Genótipos } & \multicolumn{4}{|c|}{ 6-8 folhas } & \multicolumn{3}{|c|}{$10-12$ folhas } \\
\hline & \multicolumn{3}{|c|}{ Média ( \pm EP) } & \multirow{2}{*}{$\frac{\text { I.V. }}{2,45-3,20}$} & \multicolumn{2}{|l|}{ Média ( $\pm E P)$} & \multirow{2}{*}{$\frac{\text { I.V. }}{2,65-3,70}$} \\
\hline Dina 766 & $2,97 \pm 0,11$ & $a$ & $A$ & & $3,14 \pm 0,18$ & A & \\
\hline CATI AL 30 & $3,04 \pm 0,27$ & $a b$ & A & $2,40-3,88$ & $3,58 \pm 0,15$ & A & $3,00-4,13$ \\
\hline IAC-Vitória & $3,11 \pm 0,18$ & $a b$ & A & $2,40-3,58$ & $3,12 \pm 0,27$ & A & $2,25-4,05$ \\
\hline IAC-Pariquera & $3,20 \pm 0,11$ & $a b$ & A & $2,78-3,53$ & $3,35 \pm 0,16$ & A & $2,73-3,83$ \\
\hline C 333 B & $3,21 \pm 0,08$ & $a b$ & $A$ & $3,03-3,55$ & $3,26 \pm 0,25$ & A & $2,63-4,23$ \\
\hline IAC-21 & $3,22 \pm 0,17$ & $a b$ & A & $2,55-3,63$ & $3,58 \pm 0,13$ & A & $3,20-4,15$ \\
\hline Z 8486 & $3,28 \pm 0,12$ & $a b$ & A & $2,75-3,60$ & $3,22 \pm 0,12$ & A & $2,75-3,65$ \\
\hline Piranão VF1 & $3,28 \pm 0,14$ & $a b$ & A & $2,83-3,85$ & $3,50 \pm 0,23$ & A & $2,85-4,23$ \\
\hline AG 1051 & $3,38 \pm 0,11$ & $a b$ & A & $2,93-3,70$ & $3,40 \pm 0,09$ & A & $3,23-3,75$ \\
\hline XL 212 & $3,48 \pm 0,13$ & b & A & $2,88-3,75$ & $3,60 \pm 0,11$ & A & $3,23-3,90$ \\
\hline Master & $3,58 \pm 0,20$ & b & B & $2,85-4,35$ & $2,91 \pm 0,11$ & A & $2,53-3,23$ \\
\hline Exceler & $3,63 \pm 0,27$ & b & A & $2,98-4,90$ & $3,11 \pm 0,22$ & A & $2,55-3,93$ \\
\hline C.V, (\%) & & & 26,8 & & & 8,6 & \\
\hline
\end{tabular}

Médias ( $\pm \mathrm{EP})$ seguidas de mesma letra minúscula nas colunas não diferem estatisticamente entre si pelo teste de Duncan $(p<0,05)$.

Médias $( \pm E P)$ seguidas de mesma letra maiúscula nas linhas não diferem estatisticamente entre si pelo teste t pareado $(p<0,05)$.

\subsubsection{Resultados da análise de variância conjunta em Florínea - SP}

Os resultados da análise de variância entre as épocas de cultivo (Tabela 14) evidenciaram que houve significância para o fator época $(p=0,0001)$, indicando que em pelo menos uma das épocas avaliadas os danos foram diferentes. Na análise de variância para o fator idade, dentro das épocas de cultivo (Tabela 15), a interação idade*genótipo*época foi significativa $(p=0,0109)$, indicando que as médias dos genótipos foram distintas em todas as épocas, em cada idade, e também distintas entre as idades em todas as épocas. 
Tabela 14. Quadrados médios e significância na análise de variância conjunta entre épocas de cultivo, para danos causados por $S$. frugiperda em genótipos de milho, em Florínea - SP.

\begin{tabular}{|c|c|c|c|c|}
\hline Fonte de Variação & GL & Quadrado Médio & Valor de F & $P R>F$ \\
\hline Genótipo & 11 & 1967,34 & 3,54 & 0,0002 ** \\
\hline Época & 2 & 56345,91 & 101,36 & $0,0001 * *$ \\
\hline Genótipo x Época & 22 & 594,63 & 1,07 & 0,3838 ns \\
\hline Resíduo & 180 & 555,88 & & \\
\hline
\end{tabular}

Tabela 15. Quadrados médios e significância na análise de variância conjunta dentro das épocas de cultivo, para danos causados por $S$. frugiperda em genótipos de milho avaliados em duas idades, em Florínea - SP.

\begin{tabular}{|c|c|c|c|c|}
\hline Fonte de Variação & $\mathrm{GL}$ & Quadrado Médio & Valor de $\mathrm{F}$ & $P R>F$ \\
\hline Idade & 1 & 111542,83 & 350,71 & $0,0001^{* *}$ \\
\hline Idade x Genótipo & 11 & 471,74 & 1,48 & 0,1410 \\
\hline Idade x Época & 2 & 52666,49 & 165,59 & $0,0001^{* *}$ \\
\hline Idade x Genótipo x Época & 22 & 610,42 & 1,92 & 0,0109 \\
\hline Resíduo & 180 & 318,04 & & \\
\hline
\end{tabular}

$\mathrm{Na}$ idade de 6 a 8 folhas, a menor média de danos foi observada na safrinha $2001(3,09)$ em relação à safra 2000/2001 (3,43) que por sua vez foi ainda significativamente menor em relação à safra 1999/2000 (4,80). Na idade 10 a 12 folhas, a menor média de dano foi observada na safra 2000/2001 (2,07) em relação à safra 1999/2000 $(3,08)$ que foi ainda menor que na safrinha 2001 $(3,40)$. Quando comparadas as médias entre as idades, em cada época, verifica-se que na safra 1999/2000 os danos foram significativamente maiores 
na idade de 6 a 8 folhas $(4,80)$ em relação à idade de 10 a 12 folhas $(3,08)$, o mesmo acontecendo para a safra 2000/2001 (média de 3,43 para idade de 6 a 8 folhas e 2,07 para a idade de 10 a 12 folhas). Na safrinha 2001, houve inversão nos danos, sendo observada menor média na idade 6 a 8 folhas $(3,09)$ em relação à idade 10 a 12 folhas $(3,40)$ (Tabela 16$)$. No geral, os danos causados nas safras 1999/2000 e 2000/2001, na idade de 6 a 8 folhas, determinaram o maior dano nessa idade em relação à idade de 10 a 12 folhas (Tabela 6).

Tabela 16. Médias gerais dos genótipos entre as épocas e entre as idades dentro de cada época, para danos causados pela $S$. frugiperda em genótipos de milho em Florínea - SP.

\begin{tabular}{lcc}
\hline \multicolumn{1}{c}{ Época de Cultivo } & Idade 6-8 folhas & Idade 10-12 folhas \\
\hline Safra 99/00 & $4,80 \pm 0,23$ c B & $3,08 \pm 0,13$ b A \\
Safra 00/01 & $3,43 \pm 0,26$ b B & $2,07 \pm 0,11$ a A \\
Safrinha 2001 & $3,09 \pm 0,26$ a A & $3,40 \pm 0,26$ c B \\
C.V. (\%) & 27,29 & 37,28 \\
\hline
\end{tabular}

Médias $( \pm E P)$ seguidas de letras distintas minúsculas nas colunas diferem si pelo teste de Tukey $(p<0,05)$.

Médias $( \pm E P)$ seguidas de letras distintas maiúsculas nas linha diferem entre si pelo teste $t$ pareado $(p<0,05)$.

As médias dos danos da lagarta-do-cartucho na safra 1999/2000 (Tabela 17) evidenciaram que, na idade de 6 a 8 folhas, as menores médias foram observadas nos genótipos Dina $766(4,33)$ e C 333 B $(4,36)$, que foram significativamente distintas dos genótipos Exceler (5,20), XL 212 (5,10), Piranão $(5,00)$ e CATI AL $30(4,98)$. Na idade de 10 a 12 folhas, os genótipos IAC-21 $(2,81)$, Exceler $(2,84)$, C 333 B $(2,88)$ e IAC-Vitória $(2,89)$ apresentaram as menores médias, diferindo estatisticamente do XL 212 (3,53), enquanto em Dina 766 e IAC-Pariquera ocorreram valores intermediários $(2,97$ e 3,01, 
respectivamente). Com relação à comparação das médias de cada genótipo nas duas idades avaliadas, houve diferença significativa em todos os genótipos, sendo que, na idade de 6 a 8 folhas, foram observadas as maiores médias.

Tabela 17. Danos causados por lagartas de $S$. frugiperda sob infestação natural, em genótipos de milho, em duas idades, na safra de 1999/2000. Florínea - SP.

\begin{tabular}{|c|c|c|c|c|c|c|c|c|}
\hline \multirow[t]{2}{*}{ Genótipos } & \multicolumn{4}{|c|}{ 6-8 folhas } & \multicolumn{4}{|c|}{$10-12$ folhas } \\
\hline & \multicolumn{3}{|l|}{ Média ( \pm EP) } & \multirow{2}{*}{$\frac{\text { I.V. }}{3,80-5,55}$} & \multicolumn{3}{|l|}{ Média $( \pm E P)$} & \multirow{2}{*}{$\frac{\text { I.V. }}{2,55-3,50}$} \\
\hline Dina 766 & $4,33 \pm 0,29$ & a & $B$ & & $2,97 \pm 0,14$ & $a b$ & A & \\
\hline C 333 B & $4,36 \pm 0,22$ & a & $B$ & $3,85-5,10$ & $2,88 \pm 0,13$ & $a$ & A & $2,50-3,45$ \\
\hline AG 1051 & $4,53 \pm 0,26$ & $a b$ & B & $3,40-5,20$ & $3,09 \pm 0,20$ & $a b c$ & $A$ & $2,30-3,60$ \\
\hline IAC-Pariquera & $4,61 \pm 0,21$ & $a b$ & B & $3,75-5,15$ & $3,01 \pm 0,15$ & $a b$ & A & $2,40-3,40$ \\
\hline IAC-Vitória & $4,77 \pm 0,22$ & $a b$ & B & $4,35-5,80$ & $2,89 \pm 0,09$ & $a$ & A & $2,60-3,20$ \\
\hline Master & $4,86 \pm 0,29$ & $a b$ & B & $4,05-6,00$ & $3,12 \pm 0,16$ & $a b c$ & A & $2,55-3,70$ \\
\hline IAC-21 & $4,88 \pm 0,11$ & $a b$ & B & $4,55-5,25$ & $2,81 \pm 0,06$ & $a$ & A & $2,70-3,05$ \\
\hline Z 8486 & $4,96 \pm 0,23$ & $a b$ & B & $4,30-5,65$ & $3,33 \pm 0,10$ & $\mathrm{bc}$ & A & $2,90-3,60$ \\
\hline CATI AL 30 & $4,98 \pm 0,21$ & $\mathrm{~b}$ & B & $4,20-5,75$ & $3,23 \pm 0,13$ & $a b c$ & A & $2,95-3,65$ \\
\hline Piranão VF1 & $5,00 \pm 022$ & b & B & $4,40-5,80$ & $3,22 \pm 0,18$ & $a b c$ & A & $2,65-3,95$ \\
\hline XL 212 & $5,10 \pm 021$ & b & B & $4,25-5,55$ & $3,53 \pm 0,14$ & c & A & $3,05-3,95$ \\
\hline Exceler & $5,20 \pm 0,31$ & b & B & $4,65-6,70$ & $2,84 \pm 0,13$ & a & A & $2,35-3,20$ \\
\hline C.V. $(\%)$ & & & 7,9 & & & 27 & & \\
\hline
\end{tabular}

Médias ( \pm EP) seguidas de mesma letra minúscula nas colunas não diferem estatisticamente entre si pelo teste de Duncan $(p<0,05)$.

Médias $( \pm E P)$ seguidas de mesma letra maiúscula nas linhas não diferem estatisticamente entre si pelo teste t pareado $(p<0,05)$.

$\mathrm{Na}$ safra de 2000/2001, apenas na idade de 6 a 8 folhas foram observadas diferenças significativas entre os genótipos (Tabela 18). Nessa idade, a menor média foi observada no genótipo IAC-Vitória $(2,75)$ seguido de $C$ 333 B $(2,78)$. Esses genótipos foram significativamente distintos de XL 212 $(4,22)$ e AG $1051(3,89)$ que apresentaram as maiores médias de danos. Os genótipos Piranão $(3,75)$, IAC-Pariquera $(3,67)$ e IAC-21 $(3,67)$ também foram significativamente distintos de IAC-Vitória e C 333 B e semelhantes ao XL 212 e ao AG 1051. Na idade de 10 a 12 folhas, as médias variaram de 1,93 (IAC- 
Vitória) a 2,18 (XL 212). Com relação à comparação dos danos ocorridos nos genótipos entre as idades de plantas, verifica-se que foram maiores na idade de 6 a 8 folhas em todos os genótipos, como ocorrido na safra 1999/2000.

Tabela 18. Danos causados por lagartas de $S$. frugiperda sob infestação natural, em genótipos de milho, em duas idades, na safra de 2000/2001. Florínea - SP.

\begin{tabular}{|c|c|c|c|c|c|c|c|}
\hline \multirow[t]{2}{*}{ Genótipos } & \multicolumn{4}{|c|}{$6-8$ folhas } & \multicolumn{3}{|c|}{$10-12$ folhas } \\
\hline & \multicolumn{3}{|l|}{ Média ( \pm EP) } & \multirow{2}{*}{$\frac{\text { I.V. }}{2,10-3,65}$} & \multicolumn{2}{|l|}{ Média ( \pm EP) } & \multirow{2}{*}{$\frac{\text { I.V. }}{1,60-2,25}$} \\
\hline IAC-Vitória & $2,75 \pm 0,24$ & $a$ & B & & $1,93 \pm 0,10$ & a $\mathrm{A}$ & \\
\hline C 333 B & $2,78 \pm 0,31$ & $a b$ & B & $1,80-3,80$ & $1,94 \pm 0,07$ & a $A$ & $1,65-2,15$ \\
\hline Z 8486 & $2,93 \pm 0,27$ & $a b c$ & B & $2,25-3,90$ & $2,13 \pm 0,24$ & a $A$ & $1,48-3,13$ \\
\hline Exceler & $2,97 \pm 0,11$ & $a b c$ & B & $2,65-3,40$ & $1,94 \pm 0,07$ & a $A$ & $1,68-2,20$ \\
\hline Master & $3,36 \pm 0,31$ & abcd & B & $2,50-4,40$ & $2,13 \pm 0,15$ & a $\mathrm{A}$ & $1,75-2,83$ \\
\hline CATI AL 30 & $3,59 \pm 0,29$ & abcd & B & $2,85-4,80$ & $2,15 \pm 0,15$ & a $A$ & $1,70-2,63$ \\
\hline Dina 766 & $3,63 \pm 0,22$ & bcd & B & $2,90-4,25$ & $2,15 \pm 0,07$ & a $A$ & $1,93-2,35$ \\
\hline IAC-21 & $3,67 \pm 0,29$ & $\mathrm{~cd}$ & B & $3,00-4,75$ & $1,95 \pm 0,10$ & a $A$ & $1,73-2,38$ \\
\hline IAC-Pariquera & $3,67 \pm 0,34$ & $\mathrm{~cd}$ & B & $2,40-4,90$ & $2,16 \pm 0,10$ & a $A$ & $1,95-2,58$ \\
\hline Piranão VF1 & $3,75 \pm 0,24$ & $\mathrm{~cd}$ & B & $3,00-4,50$ & $2,05 \pm 0,05$ & a $A$ & $1,83-2,20$ \\
\hline AG 1051 & $3,89 \pm 0,21$ & d & B & $3,05-4,40$ & $2,15 \pm 0,14$ & a $A$ & $1,73-2,50$ \\
\hline XL 212 & $4,22 \pm 0,24$ & d & B & $3,40-5,10$ & $2,18 \pm 0,13$ & a $A$ & $1,65-2,60$ \\
\hline C.V.(\%) & & & & & & 44,8 & \\
\hline
\end{tabular}

Médias $( \pm E P)$ seguidas de mesma letra minúscula nas colunas não diferem estatisticamente entre si pelo teste de Duncan $(p<0,05)$.

Médias $( \pm E P)$ seguidas de mesma letra maiúscula nas linhas não diferem estatisticamente entre si pelo teste t pareado $(p<0,05)$.

Na safrinha de 2001 (Tabela 19), as menores médias, na idade de 6 a 8 folhas, foram observadas nos genótipos Exceler $(2,57)$ e Master $(2,73)$, as quais diferiram da observada no genótipo Piranão $(3,72)$. Na idade de 10 a 12 folhas, os genótipos IAC-21 $(2,95)$ e C 333 B $(3,06)$ foram os que apresentaram as menores médias. A exemplo do que aconteceu na idade de 6-8 folhas, o genótipo Piranão foi o que apresentou a maior média $(4,10)$. Com relação à comparação das médias de cada genótipo, nas duas idades avaliadas não houve diferenças significativas, à exceção do genótipo Exceler, que apresentou 
a média de 2,57 na idade de 6 a 8 folhas, significativamente distinta do valor 3,62 obtido na idade de 10 a 12 folhas.

Tabela 19. Danos causados por lagartas de $S$. frugiperda sob infestação natural, em genótipos de milho, em duas idades, na safrinha de 2001. Florínea - SP.

\begin{tabular}{|c|c|c|c|c|c|c|c|c|}
\hline \multirow[t]{2}{*}{ Genótipos } & \multicolumn{4}{|c|}{$6-8$ folhas } & \multicolumn{4}{|c|}{$10-12$ folhas } \\
\hline & \multicolumn{3}{|l|}{ Média $( \pm E P)$} & \multirow{2}{*}{$\frac{\text { I.V. }}{1,48-3,63}$} & \multicolumn{3}{|l|}{ Média $( \pm E P)$} & \multirow{2}{*}{$\frac{\text { I.V. }}{3,18-4,48}$} \\
\hline Exceler & $2,57 \pm 0,35$ & $a$ & $A$ & & $3,62 \pm 0,22$ & $a b$ & B & \\
\hline Master & $2,73 \pm 0,30$ & a & $A$ & $1,55-3,65$ & $3,10 \pm 0,42$ & $a b$ & $A$ & $1,53-4,25$ \\
\hline IAC-Vitória & $2,91 \pm 0,39$ & $a b$ & A & $1,80-4,03$ & $3,24 \pm 0,35$ & $a b$ & A & $1,98-3,98$ \\
\hline IAC-Pariquera & $2,98 \pm 0,21$ & $a b$ & A & $2,30-3,80$ & $3,48 \pm 0,29$ & $a b$ & A & $2,90-4,80$ \\
\hline IAC-21 & $3,08 \pm 0,31$ & $a b$ & A & $2,03-3,63$ & $2,95 \pm 0,15$ & a & A & $2,53-3,50$ \\
\hline C 333 B & $3,12 \pm 0,16$ & $a b$ & A & $2,70-3,65$ & $3,06 \pm 0,21$ & a & A & $2,43-3,70$ \\
\hline AG 1051 & $3,12 \pm 0,20$ & $a b$ & A & $2,68-3,80$ & $3,11 \pm 0,30$ & $a b$ & $A$ & $2,43-4,23$ \\
\hline Dina 766 & $3,13 \pm 0,20$ & $a b$ & A & $2,38-3,75$ & $3,51 \pm 0,15$ & $a b$ & A & $2,98-4,05$ \\
\hline CATI AL 30 & $3,15 \pm 0,29$ & $a b$ & A & $2,00-3,83$ & $3,41 \pm 0,20$ & $a b$ & A & $2,55-4,00$ \\
\hline Z 8486 & $3,25 \pm 0,16$ & $a b$ & A & $2,75-3,78$ & $3,45 \pm 0,26$ & $a b$ & A & $2,48-4,18$ \\
\hline XL 212 & $3,27 \pm 0,29$ & $a b$ & $A$ & $2,30-4,05$ & $3,71 \pm 0,26$ & $a b$ & A & $2,48-4,33$ \\
\hline Piranão VF1 & $3,72 \pm 0,22$ & b & A & $2,95-4,20$ & $4,10 \pm 0,27$ & b & A & $3,15-5,13$ \\
\hline C.V. (\%) & & & 46,4 & & & &, 1 & \\
\hline
\end{tabular}

Médias $( \pm E P)$ seguidas de mesma letra minúscula nas colunas não diferem estatisticamente entre si pelo teste de Duncan $(p<0,05)$.

Médias $( \pm E P)$ seguidas de mesma letra maiúscula nas linhas não diferem estatisticamente entre si pelo teste t pareado $(p<0,05)$.

\subsubsection{Resultados da análise de variância conjunta em Miguelópolis/ Guaíra - região norte}

Os municípios de Miguelópolis e Guaíra foram considerados representantes da região norte, quando comparada à região centro, representada pelo município de Casa Branca e à região Médio Vale do Paranapanema, representada pelo município de Florínea. Para a análise de variância conjunta, foi considerada a região para determinação das diferenças entre as idades em cada época (safra 1999/2000, em Miguelópolis e safra 2000/2001, em Guaíra). A comparação entre as épocas, em cada idade, não foi 
realizada, já que os experimentos foram realizados em locais distintos, sendo então considerados apenas para efeito de comparação entre os locais representando as diferentes regiões (Tabela 6).

$\mathrm{Na}$ análise de variância conjunta entre as épocas de cultivo (Tabela 20), os resultados foram significativos para os fatores genótipo $(p=0,0002)$ e época $(p=0,0001)$, mas não foi significativa a interação genótipo*época.

Tabela 20. Quadrados médios e significância na análise de variância conjunta entre épocas de cultivo, para danos causados por $S$. frugiperda em genótipos de milho, em Miguelópolis e Guaíra (região norte) - SP.

\begin{tabular}{|c|c|c|c|c|}
\hline Fonte de Variação & GL & Quadrado Médio & Valor de F & $\mathrm{PR}>\mathrm{F}$ \\
\hline Genótipo & 11 & 1458,67 & 3,61 & $0,0002^{* *}$ \\
\hline Época & 1 & 28248,66 & 70,00 & $0,0001^{* *}$ \\
\hline Genótipo x Época & 11 & 452,40 & 1,12 & 0,3509 ns \\
\hline Resíduo & 120 & 403,56 & & \\
\hline
\end{tabular}

$\mathrm{Na}$ análise de variância conjunta entre as idades, dentro de cada época, não houve significância nas interações entre os fatores, sendo significativo apenas para o fator idade $(p=0,0001)$ (Tabela 21$)$.

$\mathrm{Na}$ safra 1999/2000, a média geral dos danos foi significativamente menor na idade 10 a 12 folhas $(2,08)$ em relação a idade de 6 a 8 folhas $(3,50)$. Na safra 2000/2001, também os menores danos foram observados na idade de 10 a 12 folhas $(2,73)$ em relação à idade de $6-8$ folhas $(4,02)$ (Tabela 22$)$. 
Tabela 21. Quadrados médios e significância na análise de variância conjunta dentro das épocas de cultivo, para danos causados por $S$. frugiperda em genótipos de milho, avaliados em duas idades, em Miguelópolis e Guaíra (região norte) - SP.

\begin{tabular}{lrcrc}
\hline \multicolumn{1}{c}{ Fonte de Variação } & GL & Quadrado Médio & Valor de F & PR > F \\
\hline Idade & 1 & 203697,48 & 662,67 & $0,0001^{* *}$ \\
Idade x Genótipo & 11 & 400,41 & 1,30 & $0,2311^{\mathrm{ns}}$ \\
Idade x Época & 1 & 158,42 & 0,52 & $0,4742^{\mathrm{ns}}$ \\
Idade x Genótipo x Época & 11 & 225,05 & 0,73 & $0,7058^{\mathrm{ns}}$ \\
Resíduo & 120 & 307,39 & & \\
\hline $\begin{array}{l}{ }^{* *}=\text { significativo pelo teste } \mathrm{F}: \mathrm{p}<0,01 \\
\text { ns }\end{array}=$ não significativo & & & \\
\end{tabular}

Tabela 22. Médias gerais entre as épocas e entre as idades dentro de cada época, para danos causados por $S$. frugiperda em genótipos de milho em Miguelópolis e Guaíra (região norte) - SP.

\begin{tabular}{lcc}
\hline \multicolumn{1}{c}{ Época de Cultivo } & Idade 6-8 folhas & Idade 10-12 folhas \\
\hline $\begin{array}{l}\text { Safra 99/00 } \\
\text { (Miguelópolis) }\end{array}$ & $3,50 \pm 0,25 \mathrm{~B}$ & $2,08 \pm 0,18 \mathrm{~A}$ \\
$\begin{array}{l}\text { Safra 00/01 } \\
\text { (Guaíra) }\end{array}$ & $4,02 \pm 0,23 \mathrm{~B}$ & $2,73 \pm 0,13 \mathrm{~A}$ \\
C.V. (\%) & 25,89 & 44,42 \\
\hline
\end{tabular}

Médias ( \pm EP) seguidas de letras distintas minúsculas nas colunas diferem estatisticamente entre si pelo teste de Tukey $(p<0,05)$.

Médias ( $\pm E P$ ) seguidas de letras distintas maiúsculas nas linha diferem estatisticamente entre si pelo teste t pareado $(p<0,05)$.

Os resultados referentes à safra 1999/2000, em Miguelópolis, (Tabela 23) evidenciam que não houve diferenças significativas entre os genótipos tanto na idade de 6-8 folhas quanto na idade de $10-12$ folhas. Na idade de 6-8 folhas, as médias variaram de 3,08 (Z 8486) a 3,88 (XL 212). Na idade de 10-12 folhas, a variação das médias foi de 1,77 (C 333 B) a 3,11 (AG 1051). 
Tabela 23. Danos causados por lagartas de $S$. frugiperda sob infestação natural em genótipos de milho, em duas idades, na safra de 1999/2000. Miguelópolis - SP.

\begin{tabular}{|c|c|c|c|c|c|c|c|}
\hline \multirow[t]{2}{*}{ Genótipos } & \multicolumn{4}{|c|}{ 6-8 folhas } & \multicolumn{3}{|c|}{$10-12$ folhas } \\
\hline & Média $( \pm$ EP & & & I.V. & Média $( \pm E P)$ & & I.V. \\
\hline Z 8486 & $3,08 \pm 0,25$ & $a$ & B & $2,10-3,85$ & $1,87 \pm 0,19$ & a $A$ & $1,20-2,45$ \\
\hline C 333 B & $3,10 \pm 0,22$ & a & B & $2,45-4,05$ & $1,77 \pm 0,15$ & a $\mathrm{A}$ & $1,35-2,30$ \\
\hline AG 1051 & $3,12 \pm 0,20$ & a & B & $2,68-3,80$ & $3,11 \pm 0,30$ & a $A$ & $2,43-4,23$ \\
\hline CATI AL 30 & $3,26 \pm 0,32$ & a & B & $2,40-4,45$ & $1,97 \pm 0,14$ & a $A$ & $1,55-2,55$ \\
\hline IAC-Vitória & $3,43 \pm 0,25$ & a & B & $2,45-4,25$ & $2,18 \pm 0,25$ & a $A$ & $1,65-3,20$ \\
\hline IAC-Pariquera & $3,52 \pm 0,23$ & a & B & $2,70-4,15$ & $2,23 \pm 0,28$ & a $A$ & $1,55-3,50$ \\
\hline IAC-21 & $3,67 \pm 0,24$ & a & B & $3,15-4,80$ & $1,98 \pm 0,13$ & a $A$ & $1,45-2,35$ \\
\hline Piranão VF1 & $3,67 \pm 0,27$ & a & B & $2,60-4,35$ & $2,17 \pm 0,19$ & a $A$ & $1,70-2,85$ \\
\hline Master & $3,70 \pm 0,38$ & a & B & $2,75-4,95$ & $2,19 \pm 0,22$ & a $A$ & $1,60-2,85$ \\
\hline Dina 766 & $3,74 \pm 0,11$ & a & B & $3,45-4,25$ & $1,88 \pm 0,13$ & a $A$ & $1,55-2,40$ \\
\hline Exceler & $3,86 \pm 0,20$ & a & B & $3,30-4,50$ & $2,22 \pm 0,10$ & a $A$ & $2,00-2,65$ \\
\hline XL 212 & $3,88 \pm 0,30$ & a & B & $3,05-5,00$ & $2,32 \pm 0,26$ & a $A$ & $1,80-3,55$ \\
\hline C.V. $(\%)$ & & & 33,0 & & & 70,5 & \\
\hline
\end{tabular}

Médias ( $\pm E P)$ seguidas de mesma letra minúscula nas colunas não diferem estatisticamente entre si pelo teste de Duncan $(p<0,05)$.

Médias $( \pm E P)$ seguidas de mesma letra maiúscula nas linhas não diferem estatisticamente entre si pelo teste t pareado $(p<0,05)$.

Os resultados da safra 2000/2001, em Guaíra (Tabela 24) evidenciam que, na idade de 6-8 folhas, as menores médias foram verificadas nos genótipos C 333 B $(3,41)$, Master $(3,56)$ e Z 8486 (3,58) as quais foram significativamente distintas das médias apresentadas pelos genótipos XL 212 $(4,90)$ e Piranão $(4,75)$. Na idade de $10-12$ folhas, quatro genótipos, Z 8486 $(2,49)$, C 333 B (2,51), IAC-Vitória $(2,63)$ e Master $(2,64)$, apresentaram médias significativamente menores que o genótipo XL $212(3,06)$. 
Tabela 24. Danos causados por lagartas de $S$. frugiperda sob infestação natural, em genótipos de milho, em duas idades, na safra de 2000/2001. Guaíra - SP.

\begin{tabular}{llccccccc}
\hline Genótipos & \multicolumn{3}{c}{ 6-8 folhas } & \multicolumn{5}{c}{$10-12$ folhas } \\
& Média $( \pm \mathrm{EP})$ & \multicolumn{3}{c}{ I.V. } & Média $( \pm \mathrm{EP})$ & & I.V. \\
\hline C 333 B & $3,41 \pm 0,20$ & a & B & $2,70-4,00$ & $2,51 \pm 0,10$ & a & A & $2,15-2,78$ \\
Master & $3,56 \pm 0,38$ & a & B & $2,60-5,35$ & $2,64 \pm 0,11$ & a & A & $2,15-2,90$ \\
Z 8486 & $3,58 \pm 0,33$ & a & B & $2,25-4,55$ & $2,49 \pm 0,16$ & a & A & $1,98-2,93$ \\
Exceler & $3,67 \pm 0,18$ & ab & B & $2,95-4,05$ & $2,67 \pm 0,11$ & ab & A & $2,33-3,05$ \\
CATI AL 30 & $3,96 \pm 0,18$ & abc & B & $3,45-4,75$ & $2,95 \pm 0,08$ & ab & A & $2,63-3,18$ \\
IAC-21 & $4,01 \pm 0,15$ & abc & B & $3,40-4,45$ & $2,74 \pm 0,07$ & ab & A & $2,53-2,93$ \\
IAC-Vitória & $4,01 \pm 0,15$ & abc & B & $3,35-4,35$ & $2,63 \pm 0,12$ & a & A & $2,38-3,15$ \\
AG 1051 & $4,04 \pm 0,27$ & abc & B & $3,15-5,15$ & $2,79 \pm 0,16$ & ab & A & $2,30-3,43$ \\
Dina 766 & $4,05 \pm 0,26$ & abc & B & $3,25-4,90$ & $2,67 \pm 0,11$ & ab & A & $2,38-3,10$ \\
IAC-Pariquera & $4,28 \pm 0,10$ & bc & B & $4,05-4,60$ & $2,92 \pm 0,13$ & ab & A & $2,38-3,25$ \\
Piranão VF1 & $4,75 \pm 0,25$ & C & B & $3,75-5,45$ & $2,74 \pm 0,20$ & ab & A & $2,18-3,33$ \\
XL-212 & $4,90 \pm 0,31$ & C & B & $4,10-6,00$ & $3,06 \pm 0,16$ & b & A & $2,38-3,45$ \\
C.V. (\%) & & \multicolumn{1}{c}{19,6} & & & 30,9 & \\
\hline
\end{tabular}

Médias ( $\pm \mathrm{EP})$ seguidas de mesma letra minúscula nas colunas não diferem estatisticamente entre si pelo teste de Duncan $(p<0,05)$.

Médias $( \pm E P)$ seguidas de mesma letra maiúscula nas linhas não diferem estatisticamente entre si pelo teste t pareado $(p<0,05)$.

\subsubsection{Análise de agrupamento}

O dendrograma da análise de agrupamento, feito com base nos fatores local, época e idade da planta e considerando a distância euclidiana igual a 12 (Figura 4), permitiu a formação de quatro grupos de genótipos:

Grupo 1: IAC-Pariquera, AG 1051, CATI AL 30, IAC-21 e IAC-Vitória.

Grupo 2: $\quad$ Z 8486, C 333 B e Dina 766

Grupo 3: $\quad$ Master e Exceler

Grupo 4: $\quad$ XL 212 e Piranão 


\section{DENDROGRAMA PARA DISTÂNCIA EUCLIDIANA IGUAL A 12}

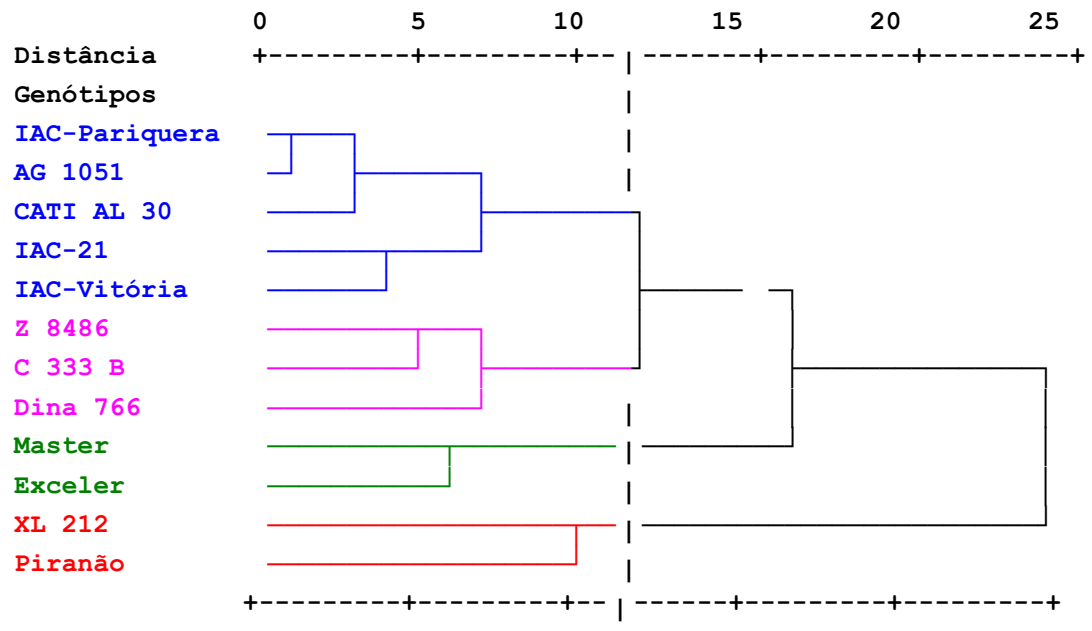

Figura 4 - Análise de agrupamento para experimentos em condições de campo em relação à "Nota de Dano", segundo a combinação de local, época de cultivo e idade de planta.

Os genótipos Dina 766, Z 8486 e C 333 B (grupo 2) foram os que apareceram com maior freqüência entre os menos danificados, não aparecendo nenhuma vez entre os mais danificados.

No grupo 4 os genótipos XL 212 e Piranão, ao contrário dos genótipos que formaram o grupo 2, foram os que apareceram com maior freqüência entre os mais danificados e não apareceram entre os menos danificados.

Os genótipos dos grupos 1 e 3 apareceram tanto entre os mais quanto entre os menos danificados, prevalecendo a posição intermediária. Entretanto, os genótipos do grupo 1 tenderam a ser mais danificados, enquanto que os do grupo 3 tenderam a ser menos danificados.

\subsubsection{Considerações gerais sobre os experimentos de campo}

A cada ano são colocadas no mercado brasileiro dezenas de novas cultivares de milho que, somadas àquelas que já se encontram em comercialização, formam a gama de material genético disponível aos 
agricultores. Entretanto, a heterogeneidade desses materiais, juntamente com os fatores abióticos e bióticos, influenciam o comportamento dessas cultivares nas diferentes regiões. No Estado de São Paulo, grande parte desses genótipos é avaliado em ensaios regionais de avaliação de cultivares; tem sido observado, nas diferentes regiões, que alguns deles sofrem maior ou menor dano em relação ao ataque da lagarta-do-cartucho. Os genótipos Z 8486, Master, C 333 B e Dina 766 estão entre aqueles que aparentam sofrer menores danos.

$\mathrm{Na}$ análise de agrupamento foram formados dois grupos de similaridade, compostos por esses genótipos. Os genótipos Z 8486, C 333 B e Dina 766 formaram o grupo 2; o genótipo Master, juntamente com o Exceler, formaram o grupo 3. O grupo 2 foi o que apresentou menores danos e o genótipo C 333 B foi o que mais vezes apareceu entre os menos danificados.

O genótipo C 333 B é um híbrido simples modificado, semi-duro amarelolaranja, destinado à produção de grãos e de ciclo normal. Possui estabilidade produtiva e grande amplitude de época de plantio, sendo considerado como padrão entre os híbridos simples e triplos nos últimos ensaios regionais de avaliação de cultivares. Em relação aos danos da lagarta-do-cartucho, ele se apresentou como menos danificado nos três locais avaliados, com exceção à safra 2000/2001 em Florínea e à safrinha 2001 em Casa Branca, quando ocupou posição intermediária entre os genótipos. Na safra 2000/2001, em Guaíra, foi o genótipo menos danificado nas duas idades avaliadas.

O genótipo Z 8486 é também um híbrido simples, semi-duro alaranjado, destinado à produção de grãos e de ciclo precoce. Nos experimentos realizados em Florínea, ele não se destacou entre os menos danificados. Entretanto, nas safras de 1999/2000 em Casa Branca e 2000/2001 em Guaíra, foi o genótipo menos danificado nas duas idades avaliadas. Foi ainda o menos danificado na primeira avaliação na safrinha de 2000 , em Casa Branca.

O genótipo Dina 766, assim como os outros dois genótipos que formaram - grupo 2, é também um híbrido simples. Tem endosperma semi-duro alaranjado e ciclo super-precoce. Apareceu entre os menos danificados nos três 
locais (em Casa Branca, na safra 1999/2000), nas duas idades avaliadas, e na safrinha 2001; em Florínea, na safra 1999/2000 e em Guaíra, na safra 2000/2001).

Assim, pelo comportamento mostrado por esses genótipos, destacandose como os menos danificados pela lagarta-do-cartucho, verifica-se que esses dados coincidem com as observações dos ensaios regionais, podendo-se encontrar neles fontes de resistência a $S$. frugiperda.

Já, em relação aos genótipos Master e Exceler, houve variação no comportamento, sendo identificados ora entre os mais danificados, ora entre os menos. Entretanto, houve tendência a serem menos danificados, o que possibilitou a formação de um grupo separado (grupo 3) na análise de agrupamento. Master e Exceler são materiais comerciais consolidados que apresentam estabilidade produtiva e características agronômicas desejáveis.

Exceler é recomendado para plantio o ano todo, sendo indicado para plantios na segunda safra. Destaca-se também nas áreas acima de $700 \mathrm{~m}$ de altitude. Na safrinha de 2000, em Casa Branca, esse genótipo ficou entre os menos danificados nas duas idades avaliadas, mas na safrinha de 2001 sofreu danos significativamente maiores, na idade de 6-8 folhas.

Master destacou-se nas duas idades avaliadas na safra 2000/2001 em Guaíra, entre os menos danificados. Na safrinha 2001, em Casa Branca, esse genótipo ficou entre os que sofreram maiores danos na primeira avaliação (V6V8), recuperando-se na segunda avaliação (V10-V12), ficando entre os menos danificados.

Entre os genótipos observados como mais danificados nos ensaios regionais, estão XL 212 e AG 1051.

O genótipo XL 212 é um híbrido simples, dentado amarelo-laranja, de ciclo normal e destinado à produção de grãos. No presente trabalho, foi o genótipo que mais apareceu entre os que sofreram maiores danos pela lagartado-cartucho, nos três locais onde foram realizados experimentos. Em cada local, em pelo menos uma época, ele foi mais danificado tanto na idade de 6 a 8 
folhas quanto na de 10 a 12 folhas (safrinha 2001 em Casa Branca; safra 1999/2000 em Florínea; safra 2000/2001 em Guaíra). À exceção da safrinha 2001 em Florínea, nas demais épocas e locais, onde houve diferença significativa entre os genótipos, XL 212 ficou entre os mais danificados, ou na primeira ou na segunda avaliação. $\mathrm{Na}$ análise de agrupamento formou, juntamente com o genótipo Piranão, um grupo de similaridade de genótipos mais danificados (grupo 4). Piranão é uma variedade identificada como suscetível ao ataque de $S$. frugiperda, sendo utilizada como padrão de suscetibilidade em estudos de melhoramento de milho resistente a essa praga (Nishikawa, 1999; Alvarez, 2001). Dessa forma, confirmou-se nos experimentos de campo o que fora observado nos ensaios regionais em relação ao genótipo XL 212.

Já, com o genótipo AG 1051, um híbrido duplo, dentado amarelo, de ciclo normal e destinado à produção de milho verde, não foram observados danos significativos. Nos locais e épocas avaliados, esse genótipo comportou-se de maneira intermediária; apenas na safra de 2000/2001, em Florínea, ficou entre os mais danificados, juntamente com os genótipos XL 212, Piranão, IACPariquera e IAC-21. Em geral, nos plantios destinados à produção de milho verde, é realizado maior número de aplicações de inseticidas para controle da lagarta-do-cartucho.

$\mathrm{Na}$ análise de agrupamento, as variedades ficaram dentro do grupo 1, formado por genótipos que, a exemplo do grupo 3 , oscilaram entre os mais e os menos danificados. O genótipo IAC-Pariquera ficou em posição intermediária, à exceção da safrinha 2000, em Casa Branca, onde ficou entre os mais danificados nas duas avaliações. Já, o genótipo IAC-Vitória apareceu entre os menos danificados nas safras 1999/2000 e 2000/2001, em Florínea e na safra 1999/2000 em Guaíra. Em Casa Branca, apresentou posição intermediária em todas as épocas. 


\subsection{Experimentos em condições de laboratório}

\subsubsection{Desenvolvimento de S. frugiperda em genótipos de milho}

\subsubsection{Peso de lagartas}

Tanto para lagartas pesadas aos 7 como aos 14 dias, verificaram-se diferenças significativas entre os genótipos (Tabela 25). Na pesagem das lagartas aos 7 dias, os menores valores foram encontrados nos genótipos $Z$ 8486 (42,35 mg) e Master (42,36 mg), em relação ao XL 212 (64,17 mg). Esses genótipos foram também os que apresentaram diferenças significativas na pesagem aos 14 dias, ocorrendo em Master (508,97 mg) e em Z 8486 (511,18 $\mathrm{mg}$ ) menores valores que em XL 212 (644,93 mg).

Tabela 25. Peso (mg) de lagartas de $S$. frugiperda aos 7 e 14 dias de idade, alimentadas com folhas de diferentes genótipos de milho. Temperatura: $25 \pm 1^{\circ} \mathrm{C}$, UR: $70 \pm 10 \%$ e fotofase: $14 \mathrm{~h}$.

\begin{tabular}{|c|c|c|c|c|}
\hline \multirow[t]{2}{*}{ Genótipos } & \multicolumn{2}{|c|}{7 dias } & \multicolumn{2}{|c|}{14 dias } \\
\hline & Média ( \pm EP) & I.V. & Média ( \pm EP) & I.V. \\
\hline Z 8486 & $42,35 \pm 5,83 a$ & $21,63-57,52$ & $511,18 \pm 37,29 a$ & $405,34-601,19$ \\
\hline Master & $42,36 \pm 9,60 a$ & $18,88-73,44$ & $508,97 \pm 54,27$ a & $378,29-649,05$ \\
\hline IAC-Vitória & $44,29 \pm 7,22 a b$ & $23,70-65,57$ & $517,01 \pm 44,21 a b$ & $371,46-605,00$ \\
\hline Exceler & $45,32 \pm 8,90 a b$ & $30,97-79,41$ & $562,29 \pm 45,15 a b$ & $450,75-716,67$ \\
\hline IAC-21 & $47,95 \pm 4,31 a b$ & $31,89-55,18$ & $551,37 \pm 50,45 a b$ & $416,42-642,97$ \\
\hline C 333 B & $49,60 \pm 4,15 a b$ & $33,54-57,33$ & $567,34 \pm 2,46 a b$ & $561,99-575,52$ \\
\hline IAC-Pariquera & $50,46 \pm 7,95 a b c$ & $24,99-69,76$ & $577,61 \pm 21,39 a b$ & $513,11-636,42$ \\
\hline Piranão VF1 & $52,82 \pm 7,83 a b c$ & $27,80-74,92$ & $586,14 \pm 23,05 a b$ & $534,87-639,95$ \\
\hline CATI AL 30 & $53,68 \pm 9,49 a b c$ & $19,59-75,33$ & $576,91 \pm 39,86 a b$ & $427,59-665,77$ \\
\hline AG 1051 & $53,77 \pm 8,24 a b c$ & $24,94-71,36$ & $560,97 \pm 21,54 a b$ & $486,56-602,20$ \\
\hline Dina 766 & $58,25 \pm 8,19$ & $30,02-75,04$ & $611,93 \pm 28,39 a b$ & $562,40-720,53$ \\
\hline XL 212 & $64,17 \pm 9,05$ & $39,19-84,76$ & $644,93 \pm 31,76 \quad b$ & $552,90-729,05$ \\
\hline C.V. (\%) & 19,1 & & 11,79 & \\
\hline
\end{tabular}




\subsubsection{Duração e viabilidade da fase larval}

Verificou-se diferença estatística para a viabilidade larval, mas em relação ao tempo de desenvolvimento das lagartas não houve distinção entre os genótipos (Tabela 26). A duração da fase larval variou entre 17,70 dias (XL 212) e 18,75 dias (Master). A viabilidade larval foi afetada negativamente pelos genótipos Z $8486(84,8 \%)$ e IAC-Vitória $(86,4 \%)$, os quais foram significativamente distintos do valor obtido no genótipo Dina 766 , que apresentou o maior percentual de sobrevivência de lagartas (96\%).

Tabela 26. Duração (dias) e viabilidade (\%) da fase larval de S. frugiperda alimentada com folhas de diferentes genótipos de milho. Temperatura: $25 \pm 1^{\circ} \mathrm{C}$, UR: $70 \pm 10 \%$ e fotofase: $14 \mathrm{~h}$.

\begin{tabular}{|c|c|c|c|c|}
\hline \multirow[t]{2}{*}{ Genótipos } & \multicolumn{2}{|c|}{ Duração } & \multicolumn{2}{|c|}{ Viabilidade } \\
\hline & Média $( \pm E P)$ & I.V. & Média $( \pm E P)$ & I.V. \\
\hline $\mathrm{XL} 212$ & $17,70 \pm 0,25 a$ & $17,09-18,26$ & $90,4 \pm 2,71 a b$ & $84-100$ \\
\hline Dina 766 & $17,75 \pm 0,30 a$ & $17,23-18,88$ & $96,0 \pm 2,19 a$ & $88-100$ \\
\hline Piranão VF1 & $17,84 \pm 0,09 a$ & $17,57-18,06$ & $87,2 \pm 3,88 a b$ & $72-92$ \\
\hline AG 1051 & $17,98 \pm 0,17 a$ & $17,64-18,62$ & $88,8 \pm 2,33 a b$ & $84-96$ \\
\hline CATI AL 30 & $18,01 \pm 0,54 a$ & $17,26-20,14$ & $88,0 \pm 2,53 a b$ & $80-92$ \\
\hline IAC-Pariquera & $18,11 \pm 0,20 a$ & $17,78-18,82$ & $91,2 \pm 1,50 a b$ & $88-96$ \\
\hline C 333 B & $18,19 \pm 0,07 a$ & $17,95-18,33$ & $87,2 \pm 3,44 a b$ & $76-96$ \\
\hline IAC-Vitória & $18,33 \pm 0,35 a$ & $17,27-19,21$ & $86,4 \pm 3,25 \quad b$ & $76-96$ \\
\hline Exceler & $18,33 \pm 0,37 a$ & $17,13-19,09$ & $90,4 \pm 2,71 a b$ & $80-96$ \\
\hline IAC-21 & $18,37 \pm 0,51 a$ & $17,38-19,83$ & $90,4 \pm 2,99 a b$ & $80-96$ \\
\hline Z 8486 & $18,64 \pm 0,28 a$ & $17,90-19,22$ & $84,8 \pm 2,65 b$ & $76-92$ \\
\hline Master & $18,75 \pm 0,52 a$ & $17,23-20,00$ & $87,2 \pm 1,96 a b$ & $80-92$ \\
\hline C.V. (\%) & & & 5,8 & \\
\hline
\end{tabular}




\subsubsection{Peso de pupas}

Para os pesos de pupas, separadas por sexo, também não houve diferenças significativas entre os genótipos, nem para machos nem para fêmeas (Tabela 27). Nos machos, os pesos médios variaram entre 245,98 mg (C 333 B) e 257,56 mg (IAC-Pariquera). Nas fêmeas, os valores ficaram entre $231,25 \mathrm{mg}$ (Z 8486) e 250,63 mg (AG 1051).

Tabela 27. Peso (mg), por sexo, de pupas de $S$. frugiperda provenientes de lagartas alimentadas com folhas de diferentes genótipos de milho. Temperatura: $25 \pm 1^{\circ} \mathrm{C}$, UR: $70 \pm 10 \%$ e fotofase: $14 \mathrm{~h}$.

\begin{tabular}{|c|c|c|c|c|}
\hline \multirow[t]{2}{*}{ Genótipos } & \multicolumn{2}{|c|}{ Machos } & \multicolumn{2}{|c|}{ Fêmeas } \\
\hline & Média ( \pm EP) & I.V. & Média ( $\pm E P)$ & I.V. \\
\hline C $333 \mathrm{~B}$ & $245,98 \pm 2,42 a$ & $239,04-253,40$ & $238,58 \pm 4,67 a$ & $223,03-251,36$ \\
\hline Z 8486 & $246,78 \pm 14,50$ & $214,88-295,03$ & $231,25 \pm 14,09 a$ & $192,44-279,26$ \\
\hline Master & $246,98 \pm 6,39 a$ & $233,40-269,48$ & $247,53 \pm 7,96 a$ & $225,11-266,05$ \\
\hline Piranão VF1 & $247,92 \pm 7,80$ & $230,79-275,18$ & $248,33 \pm 9,05$ a & $224,18-274,04$ \\
\hline IAC-Vitória & $248,04 \pm 6,57 a$ & $233,48-270,68$ & $245,57 \pm 7,62 a$ & $230,40-269,91$ \\
\hline Dina 766 & $249,81 \pm 7,13$ & $235,93-273,71$ & $247,48 \pm 6,76 a$ & $232,35-269,68$ \\
\hline XL 212 & $249,98 \pm 8,65 a$ & $222,14-268,15$ & $242,61 \pm 9,63$ a & $218,63-263,53$ \\
\hline CATI AL 30 & $250,43 \pm 7,54 a$ & $240,37-279,91$ & $239,40 \pm 4,27 a$ & $226,13-248,87$ \\
\hline Exceler & $251,61 \pm 10,04$ & $226,47-281,89$ & $244,05 \pm 12,76$ a & $218,09-286,19$ \\
\hline IAC-21 & $252,38 \pm 9,08 a$ & $224,56-273,88$ & $249,22 \pm 5,28 a$ & $236,30-265,58$ \\
\hline AG 1051 & $255,04 \pm 13,24$ & $215,49-284,71$ & $250,63 \pm 8,98 a$ & $223,99-273,68$ \\
\hline IAC-Pariquera & $257,56 \pm 7,89$ & $229,37-273,85$ & $247,77 \pm 12,16 a$ & $217,04-290,94$ \\
\hline C.V. (\%) & & & 5,47 & \\
\hline
\end{tabular}

Médias seguidas de mesma letra nas colunas não diferem estatisticamente entre si pelo teste de Duncan $(p<0,05)$. 


\subsubsection{Duração e viabilidade da fase pupal}

Não foram observadas diferenças significativas entre os genótipos em relação aos parâmetros duração e viabilidade da fase pupal (Tabela 28). Na duração média da fase pupal, os valores ficaram entre 10,87 dias (C 333 B) e 11,42 dias (IAC-Vitória). Para a viabilidade pupal, os valores variaram entre 85,59\% (IAC-21) e 92,24\% (Piranão).

Tabela 28. Duração (dias) e viabilidade (\%) da fase pupal de S. frugiperda proveniente de lagartas alimentadas com folhas de diferentes genótipos de milho. Temperatura: $25 \pm 1^{\circ} \mathrm{C}$, UR: $70 \pm 10 \%$ e fotofase: $14 \mathrm{~h}$.

\begin{tabular}{lcrccc}
\hline Genótipos & \multicolumn{2}{c}{ Duração } & \multicolumn{2}{c}{ Viabilidade } \\
& Média $( \pm \mathrm{EP})$ & \multicolumn{1}{c}{ I.V. } & Média $( \pm \mathrm{EP})$ & I.V. \\
\hline C 333 B & $10,87 \pm 0,12$ a & $10,62-11,24$ & $85,60 \pm 5,30$ a & $68,42-100$ \\
IAC-21 & $10,89 \pm 0,26$ a & $10,06-11,69$ & $85,59 \pm 2,09$ a & $80,00-91,67$ \\
Dina 766 & $10,90 \pm 0,09$ a & $10,57-11,09$ & $91,57 \pm 1,51$ a & $86,36-95,83$ \\
Master & $10,96 \pm 0,13$ a & $10,61-11,23$ & $87,13 \pm 2,99$ a & $77,27-95,65$ \\
Piranão & $10,98 \pm 0,17$ a & $10,57-11,43$ & $92,24 \pm 3,39$ a & $83,33-100$ \\
AG 1051 & $10,99 \pm 0,06$ a & $10,76-11,09$ & $89,90 \pm 3,57$ a & $76,19-95,83$ \\
XL 212 & $11,09 \pm 0,14$ a & $10,84-11,55$ & $92,06 \pm 3,54$ a & $81,82-100$ \\
IAC-Pariquera & $11,14 \pm 0,13$ a & $10,95-11,67$ & $89,44 \pm 3,28$ a & $78,26-95,83$ \\
Z 8486 & $11,20 \pm 0,16$ a & $10,77-11,75$ & $91,86 \pm 5,95$ a & $68,42-100$ \\
CATI AL 30 & $11,23 \pm 0,29$ a & $10,53-11,95$ & $86,27 \pm 2,19$ a & $80,00-91,30$ \\
Exceler & $11,29 \pm 0,06$ a & $11,11-11,48$ & $91,08 \pm 1,43$ a & $86,96-95,83$ \\
IAC-Vitória & $11,42 \pm 0,42$ a & $10,33-12,90$ & $90,41 \pm 4,19$ a & $78,95-100$ \\
C.V. (\%) & & 4,05 & & 6,64 & \\
\hline
\end{tabular}

Médias seguidas de mesma letra nas colunas não diferem estatisticamente entre si pelo teste de Duncan $(p<0,05)$. 


\subsubsection{Fecundidade}

Os genótipos não apresentaram diferenças significativas quanto aos parâmetros de fecundidade avaliados (Tabela 29). O número de ovos por fêmea variou entre 940,35 (IAC-Vitória) e 1.668,90 (Dina 766), enquanto que em relação ao número de ovos por postura, por fêmea, os valores variaram entre 231,37 (IAC-Vitória) a 333,27 ovos (IAC-Pariquera).

Tabela 29. Fecundidade de S. frugiperda originada de lagartas alimentadas com folhas de diferentes genótipos de milho. Temperatura: $25 \pm 1^{\circ} \mathrm{C}$, UR: $70 \pm 10 \%$ e fotofase: $14 \mathrm{~h}$.

\begin{tabular}{|c|c|c|c|c|}
\hline \multirow[t]{2}{*}{ Genótipos } & \multicolumn{2}{|c|}{ Ovos/fêmea } & \multicolumn{2}{|c|}{ Ovos/postura/fêmea } \\
\hline & Média ( $\pm E P$ ) & I.V. & Média ( $\pm E P$ ) & I.V. \\
\hline IAC-Vitória & $940,35 \pm 235,91 \quad a$ & $208-1675$ & $231,37 \pm 44,65$ a & $124-394$ \\
\hline Z 8486 & $945,45 \pm 341,18 \quad a$ & $86-1.735$ & $245,60 \pm 48,49 a$ & $86-365$ \\
\hline IAC-21 & $955,65 \pm 240,95 \quad a$ & $271-1.436$ & $263,79 \pm 17,18 a$ & $224-325$ \\
\hline AG 1051 & $1.121,20 \pm 139,41 a$ & $644-1.381$ & $278,46 \pm 16,11 a$ & $229-322$ \\
\hline CATI AL 30 & $1.188,50 \pm 239,34 a$ & $424-1.852$ & $287,31 \pm 58,42 a$ & $141-463$ \\
\hline C 333 B & $1.245,57 \pm 257,78 a$ & $648-2.110$ & $260,06 \pm 28,34 a$ & $195-366$ \\
\hline Exceler & $1.247,82 \pm 174,12 a$ & $642-1.697$ & $309,64 \pm 28,64 a$ & $230-407$ \\
\hline XL 212 & $1.263,95 \pm 257,45 a$ & $406-1.807$ & $262,03 \pm 66,68 a$ & $55-420$ \\
\hline IAC-Pariquera & $1.311,47-184,35 a$ & $832-1.765$ & $333,27 \pm 44,39 a$ & $226-489$ \\
\hline Piranão VF1 & $1.386,87 \pm 172,71 a$ & $1.053-1.845$ & $307,14 \pm 36,38 a$ & $243-439$ \\
\hline Master & $1.471,97 \pm 138,71 a$ & $1.053-1.795$ & $292,32 \pm 24,61 a$ & $234-349$ \\
\hline Dina 766 & $1.668,90 \pm 220,21 a$ & $1.067-2.372$ & $320,10 \pm 49,96 a$ & $221-474$ \\
\hline C.V. (\%) & 40,73 & & 28,67 & \\
\hline
\end{tabular}




\subsubsection{Longevidade}

Tanto para machos quanto para fêmeas, ocorreu diferença significativa no parâmetro longevidade (Tabela 30 ). Os adultos machos provenientes de lagartas alimentadas com o genótipo Z 8486, apresentaram menor longevidade (8,06 dias) em relação àquelas alimentadas com o genótipo Piranão $(10,26$ dias). Para as fêmeas, houve diferença significativa também para o genótipo $Z$ 8486 que apresentou menor longevidade (9,20 dias) em relação aos demais (variação de 11,20 a 12,55 dias, excetuando-se CATI AL 30 (10,92 dias).

Tabela 30. Longevidade (dias) de adultos machos e fêmeas de $S$. frugiperda provenientes de lagartas alimentadas com folhas de diferentes genótipos de milho. Temperatura: $25 \pm 1^{\circ} \mathrm{C}$, UR: $70 \pm 10 \%$ e fotofase: $14 \mathrm{~h}$.

\begin{tabular}{|c|c|c|c|c|}
\hline \multirow[t]{2}{*}{ Genótipos } & \multicolumn{2}{|c|}{ Machos } & \multicolumn{2}{|c|}{ Fêmeas } \\
\hline & Média ( \pm EP) & I.V. & Média ( \pm EP) & I.V. \\
\hline Z 8486 & $8,06 \pm 0,67$ a & $5,67-9,60$ & $9,20 \pm 1,27 a$ & $6,56-13,86$ \\
\hline IAC-Vitória & $8,61 \pm 0,41 a b$ & $7,67-9,93$ & $11,20 \pm 0,73 \quad b$ & $8,71-13,00$ \\
\hline XL 212 & $8,89 \pm 0,34 a b$ & $7,80-9,75$ & $12,55 \pm 1,67 \quad b$ & $7,56-17,17$ \\
\hline CATI AL 30 & $8,97 \pm 0,93 a b$ & $5,80-11,56$ & $10,92 \pm 1,15 a b$ & $6,40-12,60$ \\
\hline IAC Pariquera & $9,06 \pm 0,78 a b$ & $6,08-10,40$ & $11,27 \pm 0,83$ & $8,17-13,20$ \\
\hline Master & $9,37 \pm 0,44 a b$ & $7,83-10,10$ & $11,56 \pm 0,86 \quad b$ & $8,75-13,67$ \\
\hline IAC 21 & $9,38 \pm 1,22 a b$ & $6,00-13,40$ & $12,01 \pm 1,17$ & $8,45-14,15$ \\
\hline Exceler & $9,41 \pm 0,66 a b$ & $7,92-11,63$ & $11,31 \pm 1,43$ & $7,00-14,73$ \\
\hline Dina 766 & $9,48 \pm 0,39 a b$ & $8,56-10,36$ & $11,55 \pm 0,72 \quad b$ & $9,22-13,10$ \\
\hline C $333 \mathrm{~B}$ & $9,48 \pm 0,94 a b$ & $7,55-13,00$ & $12,19 \pm 0,97$ & $9,67-14,77$ \\
\hline AG 1051 & $9,68 \pm 0,54 a b$ & $8,00-11,11$ & $11,23 \pm 1,29$ & $7,91-15,55$ \\
\hline Piranão VF1 & $10,26 \pm 0,73 \quad b$ & $8,17-12,55$ & $11,83 \pm 1,03$ & $8,11-14,44$ \\
\hline C.V. (\%) & & & 11,97 & \\
\hline
\end{tabular}

Médias seguidas de mesma letra nas colunas não diferem estatisticamente entre si pelo teste de Duncan $(p<0,05)$. 


\subsubsection{Deformação de pupas e adultos}

Os valores percentuais de deformação de pupas e adultos (Tabela 31) evidenciam que os genótipos não apresentaram diferenças significativas quanto a esses parâmetros. Os valores de deformação de pupas variaram entre 8,15\% (IAC-21) e 1,71\% (Dina 766), enquanto que, para deformação de adultos, os percentuais ficaram entre 2,87\% (AG 1051) e 13,22\% (CATI AL 30).

Tabela 31. Deformação (\%) de pupas e adultos de S. frugiperda provenientes de lagartas alimentadas com folhas de diferentes genótipos de milho. Temperatura: $25 \pm 1^{\circ} \mathrm{C}$, UR: $70 \pm 10 \%$ e fotofase: $14 \mathrm{~h}$.

\begin{tabular}{|c|c|c|c|c|}
\hline \multirow[t]{2}{*}{ Genótipos } & \multicolumn{2}{|c|}{ Pupas } & \multicolumn{2}{|c|}{ Adultos } \\
\hline & Média ( $\pm E P)$ & I.V. & Média $( \pm E P)$ & I.V. \\
\hline IAC-21 & $8,15 \pm 1,95 a$ & $4,17-15,00$ & $6,27 \pm 2,12 a$ & $0,00-12,50$ \\
\hline C 333 B & $7,94 \pm 4,19 a$ & $0,00-21,05$ & $12,26 \pm 3,94 a$ & $4,55-27,27$ \\
\hline Exceler & $7,05 \pm 1,02 \quad a$ & $4,17-8,70$ & $7,47 \pm 2,29 a$ & $0,00-13,04$ \\
\hline AG 1051 & $6,38 \pm 1,20 a$ & $4,17-9,52$ & $2,87 \pm 1,18 a$ & $0,00-5,00$ \\
\hline CATI AL 30 & $6,30 \pm 0,98 a$ & $4,35-8,70$ & $13,22 \pm 5,33 a$ & $0,00-26,32$ \\
\hline Master & $5,64 \pm 2,72 a$ & $0,00-13,64$ & $6,62 \pm 2,10 a$ & $0,00-11,76$ \\
\hline IAC-Vitória & $5,57 \pm 0,90 a$ & $4,17-9,09$ & $10,60 \pm 2,04 a$ & $4,76-16,67$ \\
\hline XL 212 & $5,24 \pm 1,60 a$ & $0,00-9,09$ & $12,86 \pm 4,53 a$ & $0,00-22,22$ \\
\hline Z 8486 & $5,16 \pm 4,08 a$ & $0,00-21,05$ & $11,80 \pm 3,85 a$ & $4,55-25,00$ \\
\hline Piranão VF1 & $2,93 \pm 1,88 a$ & $0,00-9,09$ & $7,55 \pm 3,71$ a & $0,00-21,74$ \\
\hline IAC-Pariquera & $2,61 \pm 1,06 a$ & $0,00-4,55$ & $9,86 \pm 3,70 a$ & $4,35-23,81$ \\
\hline Dina 766 & $1,71 \pm 1,05 a$ & $0,00-4,55$ & $10,01 \pm 2,12 a$ & $4,35-17,39$ \\
\hline C.V. (\%) & \multicolumn{2}{|c|}{86,25} & \multicolumn{2}{|c|}{59,21} \\
\hline
\end{tabular}




\subsubsection{Análise de agrupamento}

O dendrograma da análise de agrupamento (Figura 5), feito com base nos parâmetros biológicos dos experimentos realizados em laboratório, a partir da distância euclidiana igual a 11, permitiu a formação de quatro grupos:

Grupo 1: Exceler; IAC-Pariquera; Piranão; AG 1051; C 333 B; CATI AL 30 e IAC-21.

Grupo 2: Master.

Grupo 3: XL 212 e Dina 766.

Grupo 4: Z 8486 e IAC-Vitória.

\section{DENDOGRAMA PARA DISTÂNCIA EUCLIDIANA IGUAL A 11}

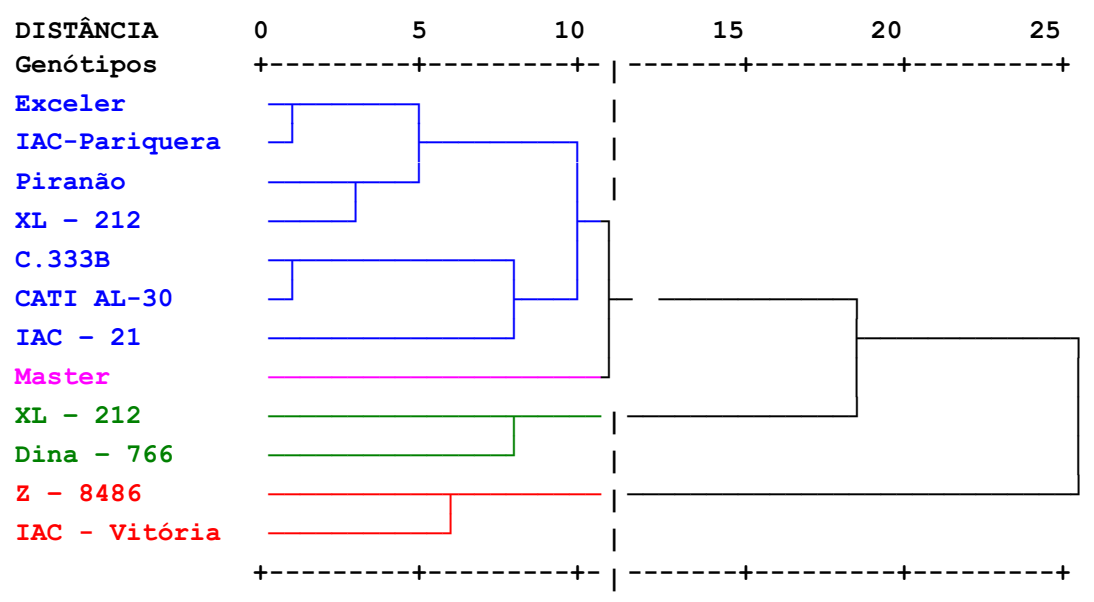

Figura 5 - Análise de agrupamento para experimentos em condições de laboratório, segundo a combinação dos diversos parâmetros biológicos utilizados.

O grupo 2 foi formado apenas pelo genótipo Master, que foi o menos favorável, apresentando menor peso larval aos 7 e aos 14 dias.

Os genótipos Z 8486 e IAC-Vitória formaram o grupo 4. Ambos apresentaram menor viabilidade larval, sendo que $Z 8486$ também apresentou menores pesos larvais, estando mais próximo do comportamento apresentado pelo genótipo Master. 
No grupo 3, os genótipos XL 212 e Dina 766 foram os que se apresentaram como mais favoráveis, principalmente quanto aos parâmetros peso de lagartas e viabilidade larval. Esses genótipos não se mostraram desfavoráveis em nenhum parâmetro.

Os demais genótipos formaram o grupo 1, apresentando comportamento intermediário entre os genótipos do grupo 3 e os genótipos dos grupos 2 e 4 .

Com base nos resultados obtidos em condições de campo e laboratório, os genótipos selecionados para o teste de não-preferência foram XL 212, IAC21, Master e C 333 B. O genótipo XL-212 foi selecionado pois se destacou ao se classificar como o mais danificado nos ensaios de campo e aquele que promoveu o maior peso larval. Em contrapartida, o genótipo Master propiciou o menor peso larval aos 7 e 14 dias e em condições de campo ficou na posição de intermediário para menos danificado. O genótipo C 333 B apresentou-se como o menos danificado no campo, mas nos testes de laboratório não teve efeito no desenvolvimento de S. frugiperda. O genótipo IAC-21 foi incluído como representante do grupo que ficou em posição intermediária, uma vez que apresentou esse comportamento tanto em campo quanto em laboratório.

\subsubsection{Não-preferência para alimentação de lagartas de $S$. frugiperda em genótipos de milho}

No teste de não-preferência para alimentação de lagartas de $S$. frugiperda, houve diferença entre os quatro genótipos avaliados (Tabela 32). $\mathrm{O}$ resultado indicou diferença significativa para o genótipo XL 212 (40,08\%) em relação aos genótipos IAC-21 (22,38\%), Master (19,17\%) e C 333 B (18,37\%), os quais não diferiram entre si. O genótipo IAC-21 se distinguiu do XL 212, mas não proporcionou maior atratividade para lagartas quando comparado aos genótipos Master e C 333 B. 
Tabela 32. Não-preferência para alimentação (\%) de lagartas recém-eclodidas de $S$. frugiperda entre genótipos de milho, em teste com chance de escolha, após 24 horas. Temperatura: $25 \pm 1^{\circ} \mathrm{C}$, UR: $70 \pm 10 \%$ e fotofase: 14h. Campinas, 2002.

\begin{tabular}{lccc}
\hline Genótipos & Média \pm EP & & I.V. \\
\hline $\mathrm{XL}-212$ & $40,08 \pm 2,38$ & $\mathrm{a}$ & $53,66-20,51$ \\
$\mathrm{IAC}-21$ & $22,38 \pm 2,44$ & $\mathrm{~b}$ & $42,11-2,50$ \\
Master & $19,17 \pm 3,06$ & $\mathrm{~b}$ & $56,41-0,00$ \\
C.333B & $18,38 \pm 2,25$ & $\mathrm{~b}$ & $35,00-5,26$ \\
C.V. $(\%)$ & 29,11 & & \\
\hline
\end{tabular}

Médias ( $\pm E P)$ seguidas de letras distintas diferem estatisticamente entre si pelo teste de Duncan, $(\mathrm{p}<0,05)$.

\subsubsection{Considerações gerais sobre experimentos de laboratório}

Williams et al. (1990) destacaram a importância dos ensaios de laboratório para investigação dos mecanismos e das bases químicas da resistência de plantas e como essas bases influenciam o desenvolvimento dos insetos. Segundo Davis et al. (1999), lagartas de S. frugiperda alimentadas em genótipos de milho resistentes têm sobrevivência reduzida; as sobreviventes têm baixo peso e se desenvolvem menos do que aquelas alimentadas em genótipos suscetíveis. Viana \& Potenza (2000) enfatizaram a importância de experimentos para avaliar parâmetros biológicos dos insetos para detecção de não-preferência e antibiose.

No presente trabalho os genótipos estudados tiveram um comportamento semelhante entre si para a maioria dos parâmetros biológicos avaliados. Foram observadas diferenças na fase larval para os parâmetros peso de lagartas e viabilidade larval. Na fase adulta, apenas a longevidade (machos e fêmeas) foi afetada significativamente e na fase pupal não foram encontradas diferenças significativas.

$\mathrm{Na}$ fase larval, para o parâmetro peso de lagartas aos 7 e aos 14 dias, houve, entre o grupo de genótipos testados, dois deles que favoreceram o 
desenvolvimento da lagarta-do-cartucho e dois deles que influenciaram o desenvolvimento negativamente. Os genótipos Master e Z 8486 apresentaram os menores pesos larvais aos 7 e aos 14 dias em relação ao XL 212, que apresentou o maior peso nas duas pesagens. O genótipo Dina 766 também diferiu dos genótipos $Z 8486$ e Master com relação ao peso, aos 7 dias.

Experimentos em condições de laboratório têm mostrado que peso e sobrevivência das lagartas de $S$. frugiperda têm sido os parâmetros mais afetados por genótipos de milho. $\mathrm{Ng}$ et al. (1985) avaliaram diversos parâmetros biológicos estudando materiais resistentes e suscetíveis. Com relação ao peso, aos 7 dias, os autores encontraram diferença de $75 \%$ a menos no peso de lagartas alimentadas em genótipos resistentes. A mortalidade larval também foi significativamente afetada, sendo obtidas viabilidades de $60 \%$ e $46 \%$ em genótipos resistentes contra $98 \%$ e $90 \%$ nos suscetíveis. Outro parâmetro destacado foi o da duração da fase larval. Lagartas que pesaram menos aos 7 dias levaram mais tempo para pupação em relação àquelas que apresentaram maior peso, chegando a 3,5 dias a mais no tempo de desenvolvimento.

No presente trabalho, a duração da fase larval variou de 17,7 dias (XL 212) a 18,7 dias (Master). Os genótipos XL 212 e Master apresentaram respectivamente maior e menor peso larval aos 7 e aos 14 dias; entretanto, o parâmetro duração da fase larval não mostrou diferenças significativas entre os genótipos. Observou-se ainda que para alguns genótipos como XL 212, Piranão e Dina 766, algumas lagartas atingiram a fase de pré-pupa por volta do $14^{\circ} \mathrm{e}$ $15^{\circ}$ dias de desenvolvimento, não sendo inclusive consideradas para o peso larval aos 14 dias. Viana \& Potenza (2000) obtiveram tempo de desenvolvimento larval de 13,9 dias para o genótipo BR-201 e 17,8 dias para o genótipo CMS-14C. Os autores também relataram que o genótipo BR-201 foi o que apresentou maior peso, maior comprimento e maior largura de cápsula cefálica aos 6 aos 13 dias. Silveira et al. (1997) encontraram valores variáveis de 14 a 17,5 dias entre genótipos resistentes e suscetíveis, respectivamente. 
Kasten Jr. et al. (1978) obtiveram duração de 13,6 dias para lagartas alimentadas em dieta natural.

Com relação aos parâmetros das fases pupal e adulta, embora os genótipos não tenham apresentado diferenças significativas, os valores obtidos foram semelhantes aos encontrados na literatura (Kasten Jr. et al., 1978; Melo \& Silva, 1987; Nalim, 1991; Vendramim \& Fancelli, 1988). Na fase adulta, o parâmetro longevidade foi significativo para machos e fêmeas, sendo o genótipo $Z 8486$ o que afetou negativamente a longevidade, tanto para machos quanto para fêmeas. Com relação à deformação de pupas e adultos, foi verificado com maior freqüência o alongamento dos urômeros entre as pupas e a deformação nas asas entre os adultos.

\subsection{Comportamento de alguns genótipos nos experimentos de campo e de laboratório}

De modo geral, neste trabalho foi possível realizar maior discriminação entre os genótipos nos experimentos de campo, uma vez que nos ensaios de laboratório a maioria dos parâmetros biológicos avaliados não apresentou diferenças significativas entre os tratamentos. $O$ efeito pouco pronunciado dos genótipos sobre a biologia do inseto sugere, em princípio, que as diferenças de dano no campo, teriam sido resultantes de variações na preferência para oviposição do inseto nos diferentes genótipos. Verificou-se um comportamento similar para alguns genótipos, nas duas condições avaliadas.

Os genótipos $Z 8486$ e C 333 B ficaram entre aqueles menos danificados no campo; o $Z$ 8486, em laboratório, promoveu menor peso larval aos 7 e aos 14 dias e menor viabilidade larval, mostrando-se como material menos adequado a S. frugiperda. Já, o genótipo C 333 B não promoveu, em laboratório, efeitos adversos ao desenvolvimento da lagarta-do-cartucho. Esse genótipo apresenta arquitetura bem definida no campo, com plantas altas e folhas de verde intenso e mais espessas quando comparadas aos demais 
genótipos testados. É utilizado nos ensaios regionais de avaliação de cultivares como padrão comercial entre os híbridos simples e triplos, sendo possível que possua fatores que provoquem não-preferência para oviposição de $S$. frugiperda. Nos experimentos de não-preferência para alimentação, com chance de escolha, realizado em laboratório, o genótipo C 333 B apresentou o menor percentual de preferência $(18,3 \%)$, diferenciando-se significativamente do XL 212, mas não dos genótipos Master e IAC-21.

Master, também incluído no teste de não-preferência em laboratório, promoveu menor peso larval aos 7 e aos 14 dias juntamente com Z 8486, diferenciando-se do XL 212. Em condições de campo apresentou posição de intermediário para menos danificado; no teste de não-preferência em laboratório foi similar aos genótipos C 333 B e IAC-21.

Entre os mais suscetíveis à lagarta-do-cartucho, em condições de campo, destacaram-se os genótipos XL 212 e Piranão, os quais sofreram danos significativamente maiores. Nos experimentos de laboratório o genótipo XL 212 também se apresentou como material favorável ao desenvolvimento larval de $S$. frugiperda, proporcionando maior peso nas duas avaliações (7 e 14 dias). Já Piranão não refletiu nas condições de laboratório o comportamento de suscetibilidade apresentado em campo, demonstrando apenas maior longevidade.

O genótipo Dina 766 também se destacou nos ensaios de laboratório junto com o XL 212 propiciando maior peso larval aos 7 dias, em relação aos genótipos Master e Z 8486. Também foi o que promoveu maior viabilidade larval em relação aos genótipos Z 8486 e IAC-Vitória. Entretanto, nos experimentos de campo, esse genótipo ficou entre os que sofreram menores danos. É possível que esse genótipo apresente não-preferência para alimentação ou para oviposição quando na presença de outros genótipos, como o que acontece em condições de campo. Esse genótipo possui porte mais baixo e folhas com um verde aparentemente menos intenso do que outros genótipos 
como Master, Exceler, Z 8486 e C 333 B, que também foram menos danificados no campo.

Entre os genótipos do tipo variedade pode-se destacar o IAC-Vitória, que em laboratório apresentou menor viabilidade larval, juntamente com Z 8486. Em campo apresentou-se como intermediário, destacando-se como menos danificado em duas avaliações realizadas em Florínea (safras 1999/2000 e 2000/2001) e também em Guaíra (safra 2000/2001). 


\section{CONCLUSÕES}

- Os danos causados por Spodoptera frugiperda (J.E. Smith, 1797) nos genótipos de milho são distintos dependendo do local e da idade da planta avaliados.

- Em Casa Branca, os menores danos ocorrem na idade de 6 a 8 folhas, enquanto que em Florínea e Miguelópolis/Guaíra isso ocorre na idade de 10 a 12 folhas.

- Em Casa Branca, verificam-se menores danos nas safrinhas em relação às safras, nas duas idades de plantas avaliadas.

- Em condições de campo, os genótipos Z 8486, C 333 B e Dina 766 são menos danificados pela lagarta-do-cartucho, enquanto que os genótipos XL 212 e Piranão são os mais danificados.

- Os resultados dos experimentos de campo corroboram as observações feitas nos ensaios regionais de avaliação de cultivares de milho do Estado de São Paulo, para os genótipos Z 8486, C 333 B e Dina 766 como menos danificados e XL 212 como mais danificado.

- A maioria dos genótipos avaliados não afeta a biologia do inseto. 
- O parâmetro peso larval é afetado negativamente pelos genótipos Master e Z 8486 em relação ao genótipo XL 212.

- A viabilidade larval nos genótipos Z 8486 e IAC-Vitória é menor que no genótipo Dina 766.

- Os genótipos C 333 B, Master e IAC-21 são menos preferidos para alimentação que o genótipo XL 212. 


\section{REFERÊNCIAS BIBLIOGRÁFICAS}

ABEL, C.A.; WILSON, R.L.; WISEMAN, B.R.; WHITE, W.H.; DAVIS, F.M. Conventional resistance of experimental maize lines to corn earworm (Lepidoptera: Noctuidae), fall armyworm (Lepidoptera: Noctuidae), Southwestern corn borer (Lepidoptera: Cambridae), and sugarcane borer (Lepidoptera: Cambridae). Journal of Economic Entomology, v.93, n.3, p.982-988, 2000.

ALVAREZ, M.D.P. Análise de cruzamento dialélico de populações de milho (Zea mays L.) para resistência à lagarta-do-cartucho (Spodoptera frugiperda Smith, 1797, Lepidoptera: Noctuidae). Piracicaba, 2001. 102p. Tese (Doutorado) - Escola Superior de Agricultura "Luiz de Queiroz", Universidade de São Paulo.

ANDREWS, K.L. Latin American research on Spodoptera frugiperda (Lepidoptera; Noctuidae). Florida Entomologist, v.71, n.4, p.630-653, 1988.

ASHLEY, T.R.; WISEMAN, B.R.; DAVIS, F.M.; ANDREWS, K.L. The fall armyworm: a bibliography. Florida Entomologist, v.72, n.1, p.152-202, 1989. 
BARRIGA, P.; VENCOVSKY, R. Heterose da produção de grãos e de outros caracteres agronômicos em cruzamentos intervarietais de milho (Zea mays L.). Ciência e Cultura, v.25, n.9, p.880-885, 1973.

BUTT, B.A.; CANTU. E. Sex determination of lepidopterous pupae. Washington: USDA, 1962. 7p.

CARVALHO, R.P.L. Danos, flutuação da população, controle e comportamento de Spodoptera frugiperda (J.E. Smith, 1797) e suscetibilidade de diferentes genótipos de milho, em condições de campo. Piracicaba, 1970. 170p. Tese (Doutorado) - Escola Superior de Agricultura "Luiz de Queiroz", Universidade de São Paulo.

CHANG, N.T.; WISEMAN, B.R.; LYNCH, R.E.; HABECK, D.H. The influence of $\mathrm{N}$ fertilization on the resistance of selected grasses to fall armyworm larvae. Journal of Agricultural Entomology, v.2, p.137-146, 1985.

CHANG, Y.; LUTHE, D.S.; DAVIS, F.M.; WILLIAMS, W.P. Influence of whorl region from resistant and susceptible corn genotypes on fall armyworm (Lepidoptera: Noctuidae) growth and development. Journal of Economic Entomology, v.93, n.2, p.477-483, 2000.

CRÓCOMO, W.B.; PARRA, J.R.P. Consumo e utilização de milho, trigo e sorgo por Spodoptera frugiperda (J.E. Smith, 1797) (Lepidoptera: Noctuidae). Revista Brasileira de Entomologia, v.29, n.2, p.225-260, 1985.

CRUZ, I. A lagarta-do-cartucho na cultura do milho. Sete Lagoas: EMBRAPA, CNPMS, 1995. 45p. (Circular Técnica, 21). 
CRUZ, I. Manejo de pragas na cultura do milho. In: SEMINÁRIO SOBRE A CULTURA DO MILHO "SAFRINHA", 5., Barretos, 1999. Cursos. Campinas: Instituto Agronômico de Campinas, 1999. p.27-56.

CRUZ, I.; TURPIN, F.T. Efeito da Spodoptera frugiperda em diferentes estádios de crescimento da cultura de milho. Pesquisa Agropecuária Brasileira, v.17, n.3, p.355-359, 1982.

CRUZ, I.; TURPIN, F.T. Yield impact of larval infestations of the fall armyworm (Lepidoptera: Noctuidae) to midwhorl growth stage of corn. Journal of Economic Entomology, v.76, n.5, p.1052-1054, 1983.

CRUZ, I.; OLIVEIRA, L.J.; OLIVEIRA, A.C.; VASCONCELOS, C.A. Efeito do nível de saturação de alumínio em solo ácido sobre os danos de Spodoptera frugiperda (J.E. Smith) em milho. Anais da Sociedade Entomológica do Brasil, v.25, n.2, p.293-297, 1996.

DAVIS, F.M.; NG, S.; WILLIAMS, W.P. Visual rating scales for screening whorl-stage corn resistance to fall armyworm. Mississipi: Mississipi State University, 1992. 9p. (Technical Bulletin, 186).

DAVIS, F.M.; WILLIAMS, W.P.; BUCKLEY, P.M. Growth responses of southwestern corn borer (Lepidoptera: Crambidae) and fall armyworm (Lepidoptera: Noctuidae) larvae fed combinations of whorl leaf tissue from a resistant and a susceptible maize hybrid. Journal of Economic Entomology, v.91, n.5, p.1213-1218, 1998. 
DAVIS, F.M.; WILLIAMS, W.P.; CHANG, Y.M.; BAKER, G.T.; HEDIN, P.A. Differential growth of fall armyworm larval (Lepidoptera: Noctuidae) reared on three phenotypic regions of whorl leaves from a resistant and a susceptible maize hybrid. Florida Entomologist, v.82, n.2, p.248-254, 1999.

DUARTE, A.P.; PATERNIANI, M.E.A.G.Z. Caracterização edafoclimática e avaliação de cultivares de milho no Estado de São Paulo. Campinas: Instituto Agronômico de Campinas, 1996. 80p. (IAC. Documentos, 56).

DUARTE, A.P.; PATERNIANI, M.E.A.G.Z. Cultivares de milho no Estado de São Paulo: resultados das avaliações regionais IAC/CATI/Empresas 1996/1997. Campinas: Instituto Agronômico de Campinas, 1997. 98p. (IAC. Documentos, 58).

DUARTE, A.P.; PATERNIANI, M.E.A.G.Z. Cultivares de milho no Estado de São Paulo: resultados das avaliações regionais - IAC/CATI/Empresas 1998/1999. Campinas: Instituto Agronômico de Campinas, 1999. 97p. (IAC. Documentos, 66).

DUARTE, A.P.; MARTINS, A.C.N.; BRUNINI, O.; CANTARELLA, H.; DEUBER, R.; PATERNIANI, M.E.A.G.Z.; TSUNECHIRO, A.; SAWASAKI, E.; DENUCCI, S.; FANTIN, G.M.; RECO, P.C. Milho safrinha - Técnicas para - cultivo no Estado de São Paulo. Campinas: Coordenadoria de Assistência Técnica Integral, 2000. 16p. (Documento Técnico, 113).

FNP CONSULTORIA \& COMÉRCIO. Agrianual 2002: anuário da agricultura brasileira. São Paulo: 2001. p.417-437:milho. 
GUIMARÃES, P.E.O.; VIANA, P.A. Sintético CMS 23 para resistência à lagartado-cartucho Spodoptera frugiperda. In: EMPRESA BRASILEIRA DE PESQUISA AGROPECUÁRIA. Centro Nacional de Pesquisa de Milho e Sorgo. Relatório técnico anual do Centro Nacional de Pesquisa de Milho e Sorgo - 1992-1993. Sete Lagoas, 1994. p.136.

HAMM, J.J.; WISEMAN, B.R. Plant resistance and nuclear polyhedrosis virus for suppression of the fall armyworm (Lepidoptera: Noctuidae). Florida Entomologist, v.69, n.3, p.541-549, 1986.

INSTITUTO DE ECONOMIA AGRÍCOLA. Estatísticas da produção vegetal, por Escritório de Desenvolvimento Rural, Estado de São Paulo,1999 milho. http://www.iea.sp.gov.br/tabelas/anu_veg989. (09 maio 2000).

ISENHOUR, D.J.; DAVIS, F.M. Dedication of 1998 armyworm symposium to Dr. Billy Ray Wiseman: plant resistance expert. Florida Entomologist, v.82, n.2, p.198-209, 1999.

KASTEN Jr., P.; PRECETTI, A.A.C.M.; PARRA, J.R.P. Dados biológicos comparativos de Spodoptera frugiperda (J.S. Smith, 1797) em duas dietas artificiais e substrato natural. Revista de Agricultura, v.53, n.1/2, p.68-78, 1978.

KAUFMAN, L.; ROUSSEEUW, P.J. Finding groups in data: an introduction to Cluster Analysis. New York: John Wiley, 1990. 342p.

LARA, F.M.; AYALA-OSUNA, J.; ABDELNUR JÚNIOR, O. Comportamento de genótipos de milho em relação ao ataque de Spodoptera frugiperda (J.E. Smith, 1797) e Heliothis zea (Bod., 1850). Científica, v.12, n.1/2, p.77-83, 1984. 
LEIDERMAN, L.; SAUER, H.F.G. A lagarta dos milharais Laphygma frugiperda (Abbot \& Smith, 1797). O Biológico, v.19, n.6, p.105-113, 1953.

LEUCK, D.B. Induced fall armyworm resistance in pearl millet. Journal of Economic Entomology, v.65, n.6, p.1608-1611, 1972.

LÓPEZ-EDWARDS, M.; HERNÁNDEZ-MENDOZA, J.L.; PESCADOR-RUBIO, A.; MOLINA-OCHOA, J.; LEZAMA-GUTIÉRREZ, R.; HAMM, J.J.; WISEMAN, B.R. Biological differences between five populations of fall armyworm (Lepidoptera: Noctuidae) collected from corn in Mexico. Florida Entomologist, v.82, n.2, p.254-262, 1999.

MELO, M.; SILVA, R.F.P. Influência de três cultivares de milho no desenvolvimento de Spodoptera frugiperda (J.E. Smith, 1797) (Lepidoptera: Noctuidae). Anais da Sociedade Entomológica do Brasil, v.16, n.1, p.3749, 1987.

MONTGOMERY, D.C. Design and analysis of experiments. 3.ed. New York: John Wiley, 1991. 649p.

NALIM, D.M. Biologia, nutrição quantitativa e controle de qualidade de populações de Spodoptera frugiperda (J.E. Smith, 1797) (Lepidoptera: Noctuidae) em dietas artificiais. Piracicaba, 1991. 150p. Tese (Doutorado) Escola Superior de Agricultura "Luiz de Queiroz", Universidade de São Paulo.

NASS, L.L.; PATERNIANI, E. Perspectivas do pré-melhoramento do milho. In: UDRY, C.V.; DUARTE, W. (Org.). Uma história brasileira do milho: o valor dos recursos genéticos. Brasília: Ed. Paralelo 15, 2000. p.43-63. 
NG, S.; DAVIS, F.M.; WILLIAMS, W.P. Survival, growth, and reproduction of the fall armyworm (Lepidoptera: Noctuidae) as affected by resistant corn genotypes. Journal of Economic Entomology, v.78, n.4, p.967-971, 1985.

NISHIKAWA, M.A.N. Análise genética de populações de milho (Zea mays L.) visando resistência à lagarta-do-cartucho Spodoptera frugiperda (Smith, 1797). Piracicaba, 1999. 98p. Tese (Doutorado) - Escola Superior de Agricultura “Luiz de Queiroz", Universidade de São Paulo.

OMOTO, C.; SCHIMIDT, F.B.; SILVA, R.B.; ZUCCHI, T.D.; RISCO, M.D.M.; TRAVALINI, C.; THOMAZINI, T.; TAKAKI, S.C. Bases for an insecticide resistance management of Spodoptera frugiperda in corn in Brazil. In: INTERNATIONAL CONGRESS OF ENTOMOLOGY, 21., Foz do Iguassu, 2000. Abstracts. Londrina: Embrapa Soja, 2000. v.1, p.347. (Documentos, 143).

PARRA, J.R.P. Técnicas de criação de insetos para programas de controle biológico. 4.ed. Piracicaba: FEALQ, 2000. 138p.

PATERNIANI, E.; CAMPOS, M.S. Melhoramento do milho. In: BORÉM, A. Melhoramento de espécies cultivadas. Viçosa: Editora UFV, 1999. p.429-485.

PATERNIANI, E.; NASS, L.L.; SANTOS, M.X. O valor dos recursos genéticos de milho para o Brasil - uma abordagem histórica da utilização do germoplasma. In: UDRY, C.V.; DUARTE, W. (Org.). Uma história brasileira do milho: o valor dos recursos genéticos. Brasília: Ed. Paralelo 15, 2000. p. 11-41. 
SCOTT, G.E.; DAVIS, F.M. Registration of Mp496 inbred of maize. Crop Science, v.21, n.2, p.353, 1981a.

SCOTT, G.E.; DAVIS, F.M. Registration of MpSWCB-4 population of maize. Crop Science, v.21, n.1, p.148, 1981b.

SCOTT, G.E.; DAVIS, F.M.; WILLIAMS, W.P. Registration of Mp701 and Mp702 germplasm lines of maize. Crop Science, v.22, n.6, p.1270, 1982.

SCRIBER, J.M.; SLANSKY Jr., F. The nutritional ecology of immature insects. Annual Review of Entomology, v.26, n.1, p.183-211, 1981.

SILVEIRA, L.C.P. Resistência de genótipos de milho a Spodoptera frugiperda (J.E. Smith, 1797) (Lepidoptera: Noctuidae). Piracicaba, 1994. 90p. Dissertação (Mestrado) - Escola Superior de Agricultura "Luiz de Queiroz", Universidade de São Paulo.

SILVEIRA, L.C.P.; VENDRAMIM, J.D.; ROSSETTO, C.J. Efeito de genótipos de milho no desenvolvimento de Spodoptera frugiperda (J.E. Smith). Anais da Sociedade Entomológica do Brasil, v.26, n.2, p.291-298, 1997.

SILVEIRA, L.C.P.; VENDRAMIM, J.D.; ROSSETTO, C.J. Não-preferência para alimentação da lagarta-do-cartucho em milho. Bragantia, v.57, n.1, p.105111, 1998.

TOZETTI, A.D.; AYALA-OSUNA, J.; BANZATTO, D.A. Avaliação genotípica de progênies de meio-irmãos do Composto Dentado (Zea mays L.) para condições de safrinha. Pesquisa Agropecuária Brasileira, v.30, n.12, p.1411-1416, 1995. 
VENDRAMIM, J.D.; FANCELLI, M. Efeito de genótipos de milho na biologia de Spodoptera frugiperda (J.S. Smith, 1797) (Lepidoptera: Noctuidae). Anais da Sociedade Entomológica do Brasil, v.17, p.141-150, 1988. Suplemento.

VENDRAMIM, J.D.; NISHIKAWA, M.A.N. Melhoramento para resistência a insetos. In: NASS, L.L.; VALOIS, A.C.C.; MELO, I.S.; VALADARIS-INGLIS, M.C. Recursos genéticos e melhoramento: plantas. Rondonópolis: Fundação MT, 2001. cap.24, p.737-781.

VIANA, P.A.; POTENZA, M.R. Avaliação de antibiose e não-preferência em cultivares de milho selecionados com resistência à lagarta-do-cartucho. Bragantia, v.59, n.1, p.27-33, 2000.

VIANA, P.A.; SILVA, A.E. Melhoramento da população de milho CMS 14 C para resistência à lagarta-do-cartucho, Spodoptera frugiperda. In: EMPRESA BRASILEIRA DE PESQUISA AGRIOPECUÁRIA. Centro Nacional de Pesquisa de Milho e Sorgo. Relatório técnico anual do Centro Nacional de Pesquisa de Milho e Sorgo - 1992-1993. Sete Lagoas, 1994. p.138.

VIANA, P.A.; GUIMARÃES, P.E.O.; PACHECO, C.A.P. Avaliação de antibiose em dialelos de milho selecionados para resistência à lagarta-do-cartucho, Spodoptera frugiperda. In: CONGRESSO NACIONAL DE MILHO E SORGO, 24., Florianópolis. 2002. Resumos. Sete Lagoas: ABMS; Embrapa Milho e Sorgo; Epagri, 2002. p.121. 
VIDELA, G.W.; DAVIS, F.M.; WILLIAMS, W.P.; NG, S. Fall armyworm (Lepidoptera: Noctuidae) larval growth and survivorship on susceptible and resistant corn at different vegetative growth stages. Journal of Economic Entomology, v.85, n.6, p.2486-2491, 1992.

WIDSTROM, N.W.; WILLIAMS, W.P.; WISEMAN, B.R.; DAVIS, F.M. Recurrent selection for resistance to leaf feeding by fall armyworm on maize. Crop Science, v.32, n.5, p.1171-1174, 1992.

WILLIAMS, W.P.; BUCKLEY, P.M. Growth of fall armyworm (Lepidoptera: Noctuidae) larvae on resistant and susceptible corn. Journal of Economic Entomology, v.85, n.5, p.2039-2042, 1992.

WILLIAMS, W.P.; DAVIS, F.M. Registration of Mp704 germplasm line of maize. Crop Science, v.22, n.6, p.1269-1270, 1982.

WILLIAMS, W.P.; DAVIS, F.M. Registration of Mp705, Mp706 and Mp707 germplasm lines of maize. Crop Science, v.24, n.6, p.1217, 1984.

WILLIAMS, W.P.; DAVIS, F.M.; SCOTT, G.E. Resistance of corn to leaf-feeding damage by the fall armyworm. Crop Science, v.18, n.5, p.861-863, 1978.

WILLIAMS, W.P.; DAVIS, F.M.; WINDHAM, G.L. Registration of Mp708 germplasm line of maize. Crop Science, v.30, n.3, p.757, 1990.

WILLIAMS, W.P.; DAVIS, F.M.; WISEMAN, B.R. Fall armyworm resistant in corn and its supression of larval survival and growth. Agronomy Journal, v.75, n.2, p.831-832, 1983. 
WILLIAMS, W.P.; BUCKLEY, P.M.; HEDIN, P.A.; DAVIS, F.M. Laboratory bioassay for resistance in corn to fall armyworm (Lepidoptera: Noctuidae) and southwestern corn borer (Lepidoptera: Pyralidae). Journal of Economic Entomology, v.83, n.4, p.1578-1581, 1990.

WISEMAN, B.R. Cumulative effects of antibiosis on five biological parameters of the fall armyworm. Florida Entomologist, v.82, n.2, p.277-283, 1999.

WISEMAN, B.R.; DAVIS, F.M. Plant resistance to insects attacking corn and grain sorghum. Florida Entomologist, v.73, n.3, p.446-458, 1990.

WISEMAN, B.R.; DAVIS, F.M. Plant resistance to the fall armyworm. The Florida Entomologist, v.62, n.2, p.123-130, 1979.

WISEMAN, B.R.; WIDSTROM, N.W. Comparison of methods of infesting whorlstage corn with fall armyworm larvae. Journal of Economic Entomology, v.73, n.3, p.440-442, 1980.

WISEMAN, B.R.; WIDSTROM, N.W. Mechanisms of resistance in "Zapalote Chico" corn silks to fall armyworm (Lepidoptera: Noctuidae) larvae. Journal of Economic Entomology, v.79, n.5, p.1390-1393, 1986.

WISEMAN, B.R.; DAVIS, F.M.; WILLIAMS, W.P. Fall armyworm: larval density and movement as an indication of nonpreference in resistant corn. Protection Ecology, v.5, n.1, p.135-141, 1983.

WISEMAN, B.R.; PAINTER, R.H.; WASSOM, C.E. Detecting corn seedling differences in the greenhouse by visual classification of damage by the fall armyworm. Journal of Economic Entomology, v.59, n.5, p.1211-1214, 1966. 
WISEMAN, B.R.; WASSOM, C.E.; PAINTER, R.H. An unusual feeding habit to measure differences in damage to 81 Latin-American lines of corn by the fall armyworm, Spodoptera frugiperda (J.E. Smith). Agronomy Journal, v.59, n.3, p.279-281, 1967.

WISEMAN, B.R.; WIDSTROM, N.W.; McMILLIAN, W.W. Effects of 'Antigua 2D118 resistant corn on fall armyworm feeding and survival. Florida Entomologist, v.64, n.4, p.515-519, 1981.

WISEMAN, B.R.; DAVIS, F.M.; WILLIAMS, W.P.; WIDSTROM, N.W. Resistance of a maize population, $\operatorname{FAWCC}(\mathrm{C} 5)$, to fall armyworm larvae (Lepidoptera: Noctuidae). Florida Entomologist, v.79, n.3, p.329-336, 1996.

YANG, G.; ISENHOUR, D.J.; ESPELIE, K.E. Activity of maize leaf cuticular lipids in resistance to leaf-feeding by the fall armyworm. Florida Entomologist, v.74, n.2, p.229-236, 1991.

YANG, G.; WISEMAN, B.R.; ISENHOUR, D.J.; ESPELIE, K.E. Chemical and ultrastructural analysis of corn cuticular lipids and their effect on feeding by fall armyworm larvae. Journal of Chemical Ecology, v.19, n.9, p.20552074, 1993.

YORK, J.O. Registration of Ark. SWCB Syn., Ark. Leaf feed. Res. Syn., and Ark. Corn-Borer Comp. \#1, \#2 and \#3 maize germplasm. Crop Science, v.31, n.2, p.501-502, 1991. 